L I B R A R Y

New York State Veterinary College ITHACA, NEW YORK

SF Hirst, Stanley.

593

Mites injurious to domestic animals.

M5

H66 


\section{Cornell University Library}

SF 593.M5H66

Mites injurious to domestic animals(with

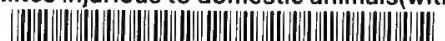

31924001182892 


\title{
BRITISH MUSEUM (NATURAL HISTORY):
}

\section{MITES INJURIOUS TO DOMESTIC ANIMALS}

(WITH AN APPENDIX ON THE ACARINE DISEASE OF HIVE BEES)

\author{
BY \\ STANLEY HIRST \\ Asgretant Kefeper, Department of Zoology
}

ILLUSTRATED WITH 85 TEXT-FIGURES

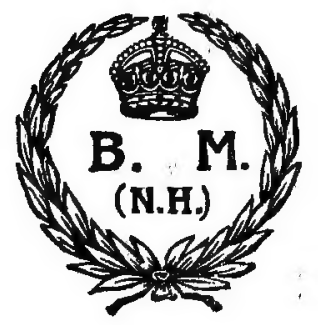

LONDON

PRINTED BY ORDER OF THE TRUSTEES OF THE BRITISH MUSEUM

$$
1922
$$

[Prige Three Shillings] 


\section{Cornell University Library}

The original of this book is in the Cornell University Library.

There are no known copyright restrictions in the United States on the use of the text. 


\title{
BRITISH MUSEUM (NATURAL HISTORY)
}

Economic Series No. 13

\section{MITES INJURIOUS TO DOMESTIC ANIMALS}

(WITH AN APPENDIX ON THE ACARINE DISEASE OF HIVE BEES)

\author{
$\mathrm{BI}$ \\ STANLEY HIRST
}

Assistant Keeper, Departant of Zoology

ILLCSTRATED WITH 85 TEXT-FIGURES

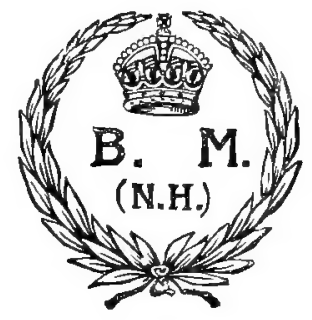

LONDON

PRINTED BY ORDER OF THE TRUSTEES

OF THE BRITISH MUSEUM

$$
\text { SOLD AT }
$$

The British Musecal (Natural History), Cromwell Road, S.W.7. AND BY

B. Quaritch, Ltd., 11, Grafton Street, New Bond Street, W.1.

Dulau \& Co., Ltd., 34-36, MARgaret Street, Cavendish Square, W. 1, and The Oxford University Press, Amen Corner, E.C. 4.

$$
1922
$$

. All Rights Reserved. 



\section{PREFACE.}

Thaxks are due to the following gentlemen, who have kindly assisted the author by the loan or gift of specimens of Acari parasitic on domestic animals, viz., Lieut.-Colonel A. Alcock, C.I.E., F.R.S., of the London School of Tropical Medicine; Professor J. H. Ashworth, D.Sc., F.R.S., Department of Zoology, University of Edinburgh; G. A. H. Bedford, Esq., Veterinary Dept., Union of South Africa; F. C. Bishopp, Esq., United States Dept. of Agriculture; Professor O. Charnock Bradley, M.D., D.Sc., M.R.V.C.S., Royal (Dick) Veterinary College, Edinburgh ; Rev. G. H. Hewison, II.A. ; Dr. M. Langeron, Laboratoire de Parasitologie, Faculté de Médecine, Université de Paris; Professor R. G. Linton, M.R.C.V.S., Royal (Dick) Veterinary College, Edinburgh; Leslie Linzell, Esq., late of the Royal Army Veterinary Corps ; Prof. A. Martin, École Nationale Vétérinaire, Toulouse; C. D. Soar, Esq.; Prof. E. L. Trouessart, Muséum d'Histoire Naturelle, Paris.- Also to Miss E. Knight, of the Cancer Research Laboratory, Middlesex Hospital.

The majority of the illustrations are reproductions of drawings made by Mr. P. Highley and Mr. A. J. E. Terzi. These have been drawn with great skill and care, and the thanks of the Trustees are due to Mr. Hirst - whose property they are-for allowing them to be used. Fig. 78 is from a photo by the Rev. G. H. Hewison, M.A. Fig. 54 is reproduced by permission of Dr. Walter E. Collinge. Figs. 62-66, 69 (a), 70, and 71 by permission of Dr. G. A. K. Marshall, C.M.G. Figs. 40 and 79-83, by permission of Messrs. Taylor and Francis. Figs. 1, 3, and 34 by permission of the Quekett Microscopical Society.

\section{TATE REGAN,}

Keeper "f Zoology.

Fcbruary, 1922. 



\section{CONTENTS.}

List OF ILLUSTRATIONS

INTRODUCTION $\quad . \quad$. $\quad . \quad$. . . . 11

Systematic Index and List of Families of Acari • • 13

Mites Injurious to Domestic Anmals . . . . 15

Appendix. On the Acarine Disease of Hive Bees . $\quad 94$

On Mounting Mites for examination under the Micro-

SCOPE . . . . . . . . . 103

Literature . $\quad . \quad$. . . . . . . 104

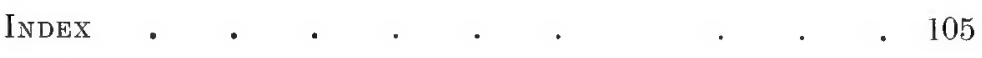





\section{LIST OF ILLUSTRATIONS.}

Text-Figures.

FrG. 1.-Otodectes cynotis, var. felis, showing distribution of tracheal tubes. (a) Portion of tube greatly magnified to show striation

PAGE

,2.-(a) Distal end of leg of Chorioptes or Otodectes . 1 (:

(b) Distal end of leg of Psoroptes. 16

, 3.-Posterior abdominal lobes of males of Psoroptes . $\quad 17$

, 4.-Ventral view of male nymph of Psoroptes communis, var. ovis. (a) Posterior end of female (pubescent) nymph 18

, 5.-Dorsal view of male of Psoroptes communis, var, ovis . 1 .

L, 6.-Ventral view of male of Chorioptes [ = Symbiotes]. from foot of sheep. . . . . 22

, 7.-Dorsal view of male of Otodectes cynotis, var. canis. . 24

$\therefore$ 8.-Sarcoptes scabiei, var. equ, ㅇ‥ Dorsal view . 26

"9.- ," ",, ". Ventral view. . 27

$\Rightarrow$ 10.-Notoedrus cati, var. cuniculi. Dorsal view of female 28

11. " " , , . Ventral view of male . 29

"12.-Notoedrus muris. Dorsal view of female . 30

, 13.-Cnemidocoptes mutans. Dorsal view of female . 31

"14.- , , , Ventral view of male . 32

, 15.-Cnemidocoptes laevis, var. gallinae. Dorsal view of female 33

, 16.-Cytoleichus nudus. Ventral view of female . . . 34

"17. - Laminosioptes cysticola. Ventral view of female . . 35

18. - Hypopial nymph ("Hypodectes") of Falculifer rostratus . 36

,19.-Megninia sp. Ventral view of male . . 35

20.-Megninia columbae. Ventral view of male . . 38

"21._ , , (a) Tarsus of fourth leg of male.

(b) "Tarsus of third leg of male.

22.-(a) Posterior end of body of male of Megninia velata . 40

(b) , , , , , cubitalis, var. ginglymura" . . ." ." . 40

Female from above

Male from below

25.- Posterior abdominal lobes of male of (a) Pterolichus bicaudatus; (b) of $P$. sculpturatus

26. - (a) Posterior end of nymph of Pterolichus bicaudatus 44

(b) ," ", sculpturatus

27. - Plerolichus sp. Female from below. (a) Tarsus of second leg of same. (b) Denticle on first tarsus . . 45

28.-Pterolichus sp. Male from above . 46

29. - , , Cast skin of nymph . 47

30.-Freyana chanayi, o. Dorsal view . 48 
FIG 31.-Dernoglyphus elongatus. (a) Male; (b) Female

", 34. Listrophorid mite, showing distribution of tracheal tubes

36.-Hypopial or travelling nymphs of Tyroglyphidae . . 53

"37.-Tyroglyphus longior, var. castellanii, $\delta$. Dorsal and . 37.-Tyroglyphus longior, var. castellani,
ventral asperts

38.- Glycyphagus domesticus

" 39.-Cheyletid mites. (a) Psorergates musculi. Dorsal view of male. (b) Myobia sp. Dorsal view of male . 55

40.-Cheyletiella parasitivorax. Dorsal view of female . 56

", 41.-(a) Syringophilus bijectinatus. (b) S. columbae. Dorsal aspect of females

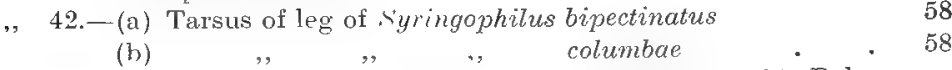

. 43.-Tydeus molestus, q". From below, (a) Lew. (b) Palp. much enlarged

,, 44.-Leytus (Trombicula?) similis

45.--Schöngastia americana

, 46. Capitulum of Demorlex folliculorum

" 47. Dorsal spinule on capitulum (palp) of Demodex spp.

48. Demodex canis, $q$. Ventral view; and capitulum from above

, 49-Denodex equi. Male and female. Also capitulum from a.bove

(b) Capitulum of same, from above. (c and d) Demodex phylloides. + . Dorsal and ventral aspects (e) D. cati, $\delta$, from above

,51.-Demodex bovis. Ventral view of female, and dorsal and lateral views of male

,. 52.-Stages in life cycle of Demodex

. 53.-(a) Penis of Demodex cati. (b) Early larva of D. bovis. ( $r, d$, and $e$ ) Penis of $D$. bovis.

" 54.-Anterior end of Dermanyssus, showing chelicerae in situ.

, 55.-Dermanyssus gallinae, $q$. Dorsal view

, 56.- " ,,$\quad$. Tentral view

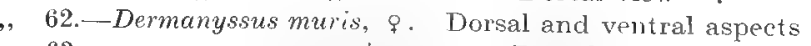

, 68.-(a) Posterior end of dorsal shield of Liponyssus bursa, \& , $\quad 80$

(h) ", , , , ", sylviarum. \& 
H'T. 69.-(a) Liponyssus bursa, 3. From below .

(b) ", sylviarum, of. From below

"70.-Liponyssus bursa, dorsal aspect of protonymph

, 71.-Laelaps echidninus, 9 . From below

, 72.-Raillietia auris, $q$. Dorsal aspect.

,73.- , ,, o. Ventral aspect

"74.- of male".

(a) Second leg of male.

(b) Chelicera

, 75. - Sternostomum rhynolethrum, 9. Dorsal view

, 78. - Tracheal tube of honey bee infested with Acarapis woodi

'79.-Acarapis woodi, \&. Dorsal aspect

, 80.- " ,, Q. Ventral aspect

, 81. , ", "\%. Dorsal aspect

(b) The same still enclosed in egg-shell 



\section{INTRODUCTIUN.}

Mites, or Acari, belong to the class Arachnida, which also includes the spiders, scorpions, harvestmen, etc. Arachnids differ from Insects in having eight legs instead of six. The chief feature distinguishing mites from other Arachnids is that they have only three pairs of legs when they are hatched from the egg, the fourth pair being added later. Most Acari are very small and their body is usually unsegmented. There is great diversity of structure in the group.

The names of the principal families are given below, those dealt with in the present pamphlet being printed in heavier type than the others. Ticks are not included, but it is hoped that another pamphlet dealing with them may be issued later.

The parasitic mites found on domestic animals differ greatly in habits. They may burrow or tunnel in the skin (e.g., Sarcoptes) or live in the sebaceous glands (e.g., Demodex), or cause crusts or scabs on the surface of the skin (e.g., Psoroptes). The feather mites, or Analgesidae, as their popular name implies, live in the plumage of birds, and some even live in the interior of the quills, as do also some Trombidiidae (Syringophilus, etc.). The Listrophoridae and some Trombidiid mites ( $M$ yobia) cling to the hairs of mammals. Many of the Gamasidae live in the nests of rodents, but may also sometimes be found on their bodies. 



\section{SYSTEMATIC INDEX.}

Class Arachinida.

Order Actiri.

Family Sarcoptidae

YAGF:

Sub-order Sarcoptoidea

Canestrinidida.

Sub-order Cryptostigmata Family Oribatidae.

Sub-order Vermiformia

Family Demodicidae .

Sub-order Prostigmata $\cdot\left\{\begin{array}{cl}\text { Family } & \text { Trombididae } \\ " & \text { Erythramidat. } \\ " & \text { Hydrachnidae. } \\ " & \text { Halacaridat. } \\ " & \text { Nicoletieldidae. }\end{array}\right.$

Sub-order Heterostigma Family Tarsonemidae. 94

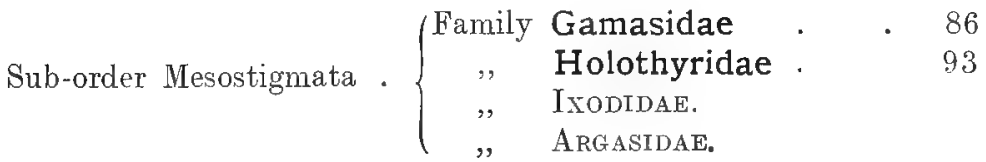

Sub-order Notostigmata Family Opilioacaridae.

Sub-order Tetrapoda Family Eriophimdae. 



\section{MITES INJURIOUS TO DOMES'IIO ANIMALS}

\section{SUb-ORDER SARCOPTOIDEA. \\ Fanily SaRcoptidide.}

The mites of this family, commonly called itch mites, are very small, whitish, and in shape oval or round. They are usually considered to be without tracheal tubes, but in the genus Otodectes (fig 1), and possibly in other members of the family, these are present.

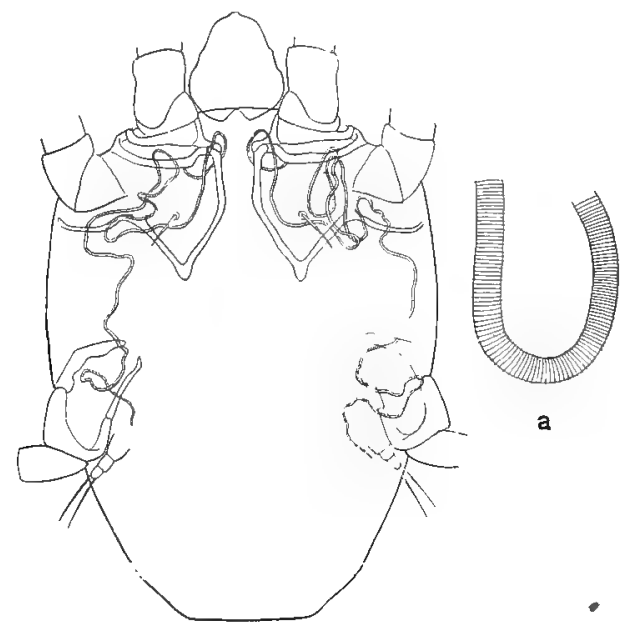

FIG. 1.

Otodectes cynotis, var. felis, showing distribution of tracheal tubes, $\times 142$. (a) Portion of tube greatly magnified to show striation. (After Hirst, Journ. Quekett Microscopical Club (2) xiv, Nov. 1921.)

Genus Psoroptes, Gervais, 1841.

The genus Psoroptes differs from the allied genera Chorioptes (formerly known as Symbiotes) and Otodectes in having the terminal 
sucker of the legs borne on a long three-segmented peduncle (fig. 2 b).

There are two distinct species of Psoroptes, viz., $P$. natalensis and $P$. communis.

\section{Psoroptes natalensis, Hirst, 1919.}

In the male of this species two of the hairs on each abdominal lobe are distinctly flattened and blade-like near the distal end (fig. $3 \mathrm{~h}$ ), but not nearly to the same extent as the modified hairs present in the same position in Chorioptes (Symbiotes).

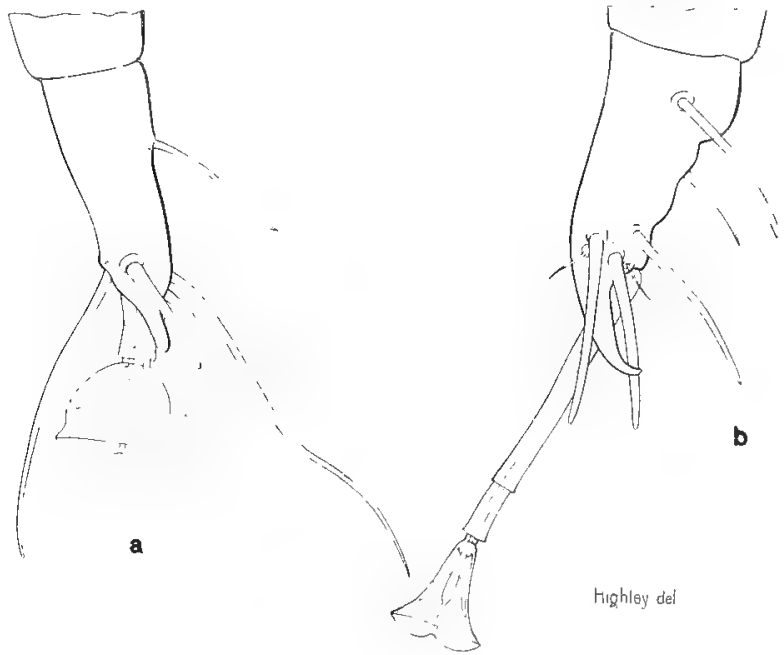

FIG. 2.

(a) Distal end of leg of (horioptes, showing the ambulacral sucker borne on a short unsegmented peduncle. (b) Distal end of leg of Psoroptes, showing the sucker borne on a long three. segmented peduncle. (Original.)

This species was first described from specimens found on cattle at Richmond, Natal. Mégnin's examples from a buffalo from Cochin China, determined by him as $P$ longirostris $[P$. communis $]$, are really referable to $P$. natalensis.

\section{Psoroptes communis, Fürstenberg, 1861}

The author has examined a large scries of specimens of Psoroptes from various domestic animals, and can find very little structural difference between them. It seems that the mites of this genus 
(with the exception of Psoroptes natalensis) should be regarded merely as races or slight varieties of a single species.

The hairs on the abdominal lobes of the male are all normal in appearance in $P$. communis (fig. $3 a-g, i$ ), none of them being in the least flattened or blade-like.

Although differing so little in structure, various observers have
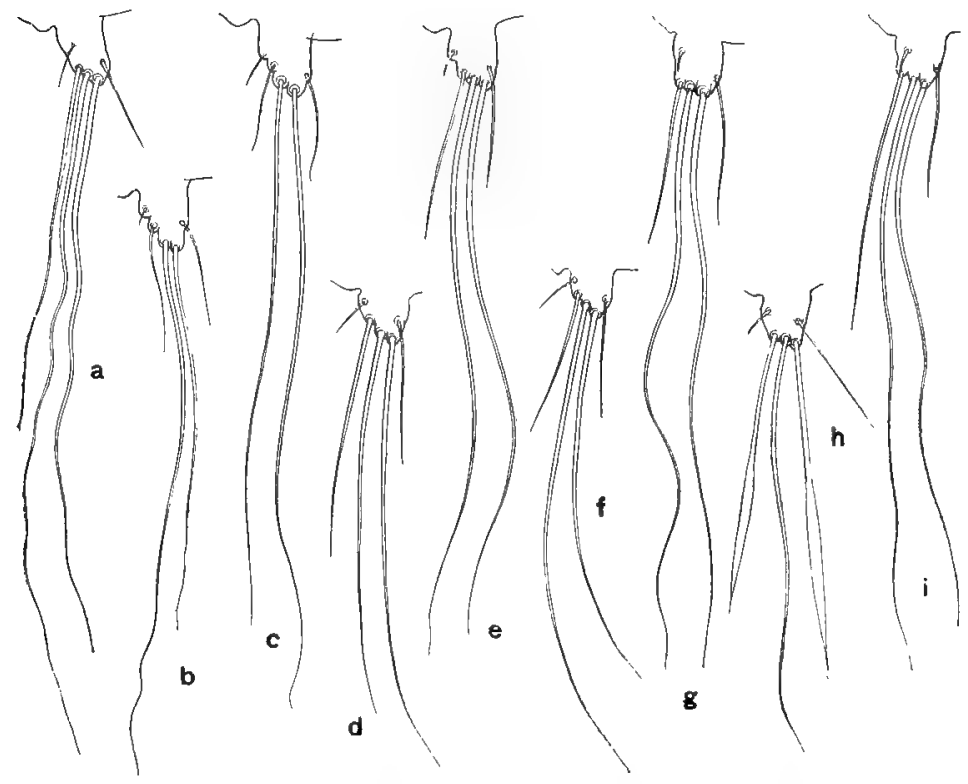

FIG. 3.

Posterior abdominal lobes of males of Psoroptes. (a) Psoroptes communis, var. equi; (b) var. ovis, (c) var. cuniculi, (d) var. bovis (from Johannesburg, South Africa); (e) var. caprae (St. Vincent, West Indies); (f) var. bovis (from Amarillo, Texas); (g) and (i) var. cervinae (Colorado); (h) Psoroptes natalensis, Hirst. (After Hirst, Journ. Quekett Microscopical Club, (2) xiv, Nov. 1921.)

pointed out that it is very difficult to transmit mites of the genus Psoroptes from one host to another of a different species. For instance, Delafond and Bourguignon failed to transmit Psoroptes communis, var. ovis, to any other host.

Psoroptes communis occurs on the following domestic animals: sheep, goats, cattle, horses and rabbits.

Scab or Psoroptic Mange in Sheep.-The variety found 
on sheep (Psoroptes communis, var. ovis, figs. 4 and 5) is of great economic importance, being the cause of the serious disease called sheep-scab, which damages the wool and also occasions much loss of stock. Whilst the sarcoptic mange

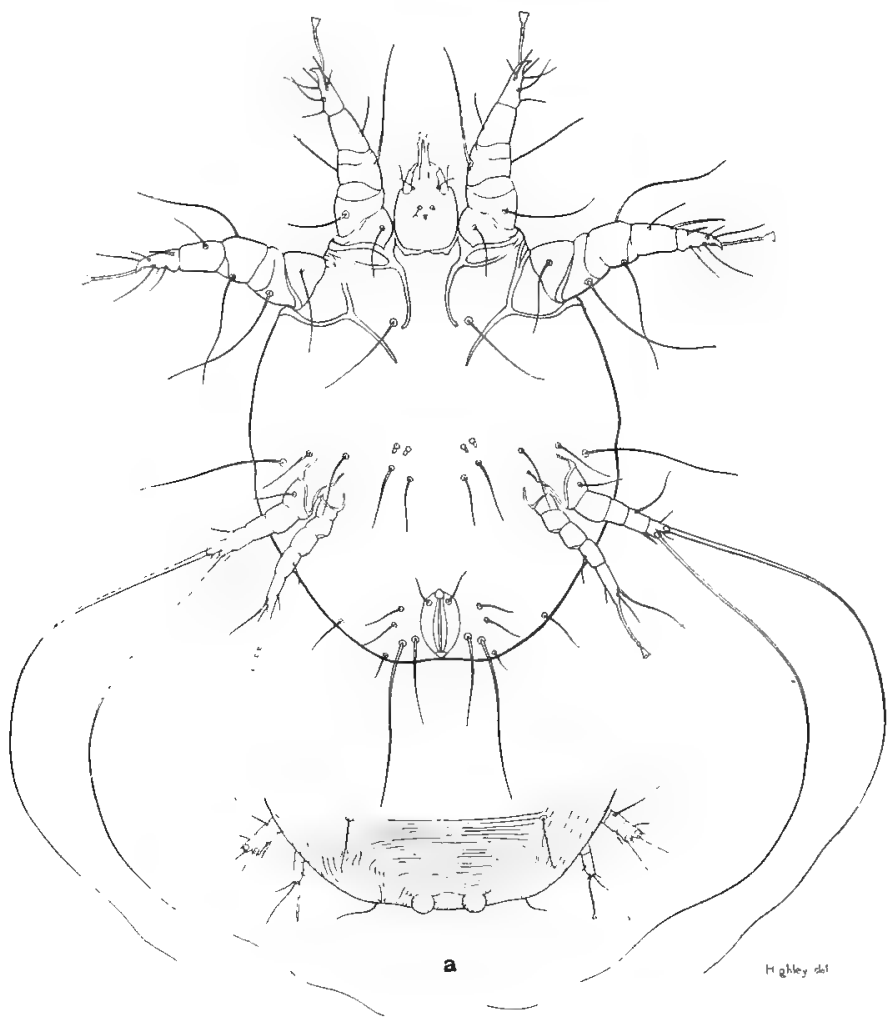

FIG. 4.

Ventral view of male nymph of Psoroptes communis, var. ovis., $\times 102$. (a) Posterior end of female (pubescent) nymph, showing the little pair of knobs that are grasped by the copulatory suckers of the adult male. (Original.)

of the sheep is restricted to the head, the psoroptic occurs on the parts of the body covered with wool. The mites do not burrow in the skin, but pierce it with their elongated mandibles. Irritation is intense, and the wool becomes detached in places, also matted and full of greasy scabs or crusts. Sheep 
suffering from scab are restless and rub themselves against posts, trees, fences, etc. The disease may be spread through healthy sheep rubbing themselves against places infected in this manner, or through actual contact with diseased sheep. This malady is

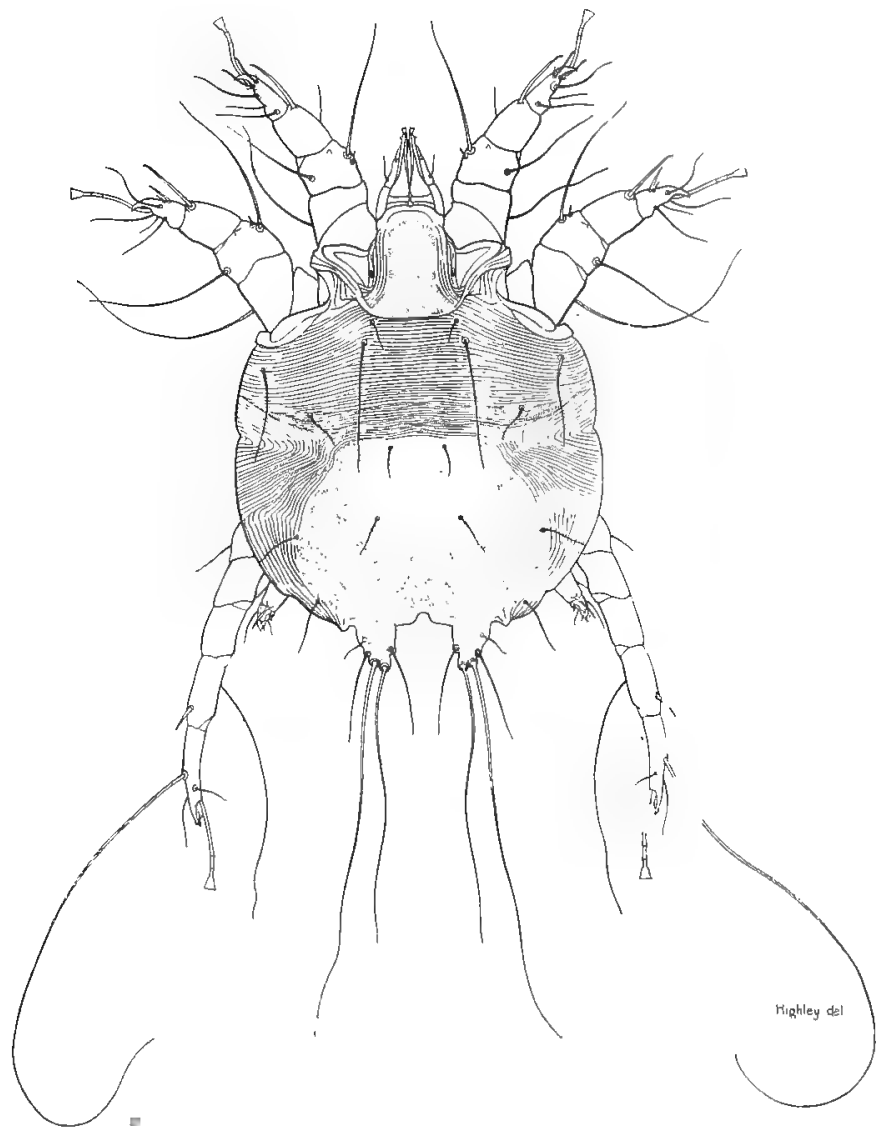

FIG. 5.

Dorsal view of male of Psoroptes communis, var. ovis, $\times 102$.

(Original.)

very contagious. The Psoroptes is sometimes found in the ears of sheep, without occurring on the body, and this source of infection should be borne in mind and the ears examined and treated if necessary.

Well-fed sheep are much more resistant to this disease than c 2 
those in poor condition, and are more easily cured. As is well-known, sheep-scals is treated by dipping, and many patent dips are on the market. The wool should be clipped from the affected parts before dipping. Most of the dippings fail to destroy the eggs, hence it is necessary to give a second immersion at an interval of about eight days in order to destroy any mites that have developed (before they start laying eggs themselves). According to Stockman and Beare creosote dip is very effective against the eggs.

Sheep in the first stage of the disease often show no visible signs, hence the necessity of systematic dipping.

Much advice on the dipping of sheep is given in leaflets Nos. 61 and 145 issued by the Ministry of Agriculture. Sheep-scab is a notifiable disease, and it is the duty of the owners of infected sheep to give notice of the fact to the nearest police constable.

A. W. Shilston has written an excellent account of the habits of Psoroptes communis, var. ovis, based on observations in South Africa (Third and Fourth Reports of the Division of Veterinary Research, Dept. of Agriculture, Union of South Africa, Nov. 1915, pp. 69-98). He points out that the all-important factor in the eradication of sheep-scab is the destruction of every mite on the sheep themselves, and that to ensure this more efficient dipping is necessary than has usually been employed in the past. He says that the interval between the first two dippings should be ten days, and that a third dipping is advisable. The expense of this third dipping is slight compared to that occasioned by a recurrence of the disease, possibly some months later, owing to the survival of a few acari on one or two sheep which may have passed too rapidly through the tank, or were not completely immersed. "In addition, a third dipping would greatly lessen the risk of reinfection from kraals or sleeping places. Acari are known to be unable to live for more than four weeks apart from sheep (in the experiments all were dead in twenty-one days), and eggs will not hatch after ten days, so that by the time the third dipping is given-say twenty to twenty-four days after the first-acari in the kraals would be dead or too feeble to infect recently dipped sheep. It would, of course, be unwise to neglect to thoroughly disinfect all places in which scabby sheep had been confined, but absolute cleansing of the sheep is the essential point in the eradication of the disease. The necessity of treating every sheep in the flock, and not only those visibly affected, is obvious." The above observations, of course, refer to sheep as kept in South Africa under different climatic conditions from those of this country. Shilston especially recommends the lime 
and sulphur dip, which, if properly used, and at the right strength, destroys the eggs as well as the mites.

Shilston was unable to infect goats by placing all stages from scabby sheep into their ears, for the mites did not live more than two days. Specimens of sheep Psoroptes were placed by him on goats, and other goats were kept in contact with scabby sheep for several months, but with negative results. Similarly, all attempts to produce otacariasis in rabbits, by infecting them with Psoroptes communis, var. ovis, were unsuccessful.

\section{Psoroptic Mange or Parasitic Otitis of the Goat.-} Psoroptes communis, var. caprae, like the variety found in rabbits, is confined to the ears of its host. Usually the presence of the mites does not seem to be harmful, but occasionally it provokes serious trouble, inducing deafness and lack of appetite, and sometimes causing the death of the infected goats.

Shilston found that $P$. communis, var. caprae, was able to live and reproduce itself on sheep, but the second generation usually died on reaching the nymphal stage, and in no case was a third generation observed.

Otacariasis of the Rabbit. - The Psoroptes of the rabbit ( $P$. communis, var. cuniculi) usually occurs only in the ear, numerous specimens being found in a yellowish substance which may fill up almost the entire cavity. Cases have been recorded in which the face, neck and limbs were also attacked, but they seem to be rare. Sometimes the body is affected with a combination of psoroptic and sarcoptic mange.

This variety of Psoroptes is quite a common parasite of English rabbits, and also occurs on the Continent, in North America, and in several parts of Africa.

$P$ communis, var. cuniculi, can apparently be transmitted to the horse, and, according to Shilston, it is able to live on sheep for periods up to seventeen days; during that time it may lay eggs and give rise to symptoms and lesions similar to those due to the sheep Psoroptes. The second generation, however, die before reproducing, and therefore continuous acariasis in sheep cannot result from infection with rabbit $P$ soroptes.

Psoroptic Mange in Cattle.-In cattle psoroptic mange commences at the base of the tail, or on the neck or withers, and gradually extends to neighbouring parts of the body; it is rarely present in a generalised form. In summer this kind of 
mange often almost completely disappears, to return again when the animals are housed during the winter months.

Psoroptic mange in the horse is dealt with on page 34.

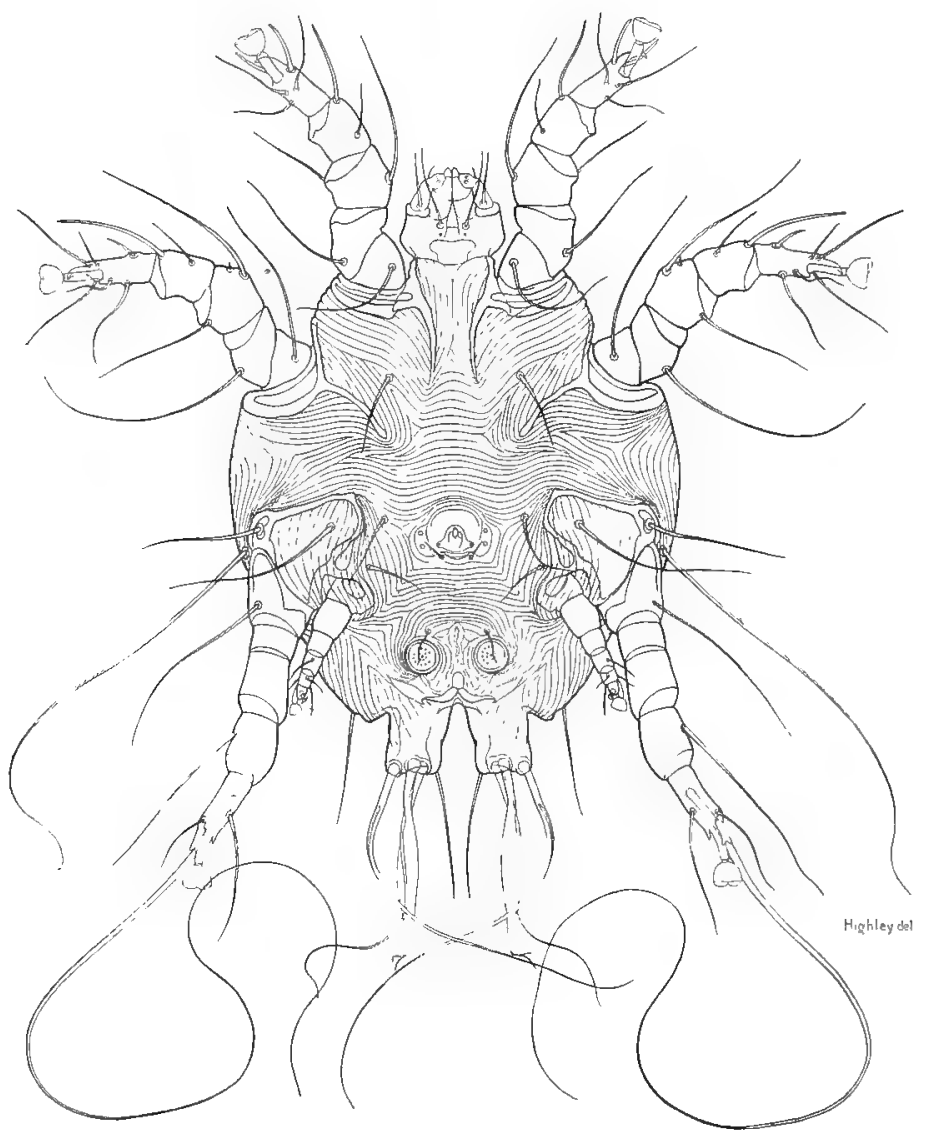

FIG. 6.

Ventral view of male of Chorioptes [= Symbiotes], from foot of sheep, $\times 195$. (Original.)

Genus Chorioptes, Gervais, 1859.

(Syn. Symbiotes, Gerlach, 1857, name pre-occupied.)

In the mites of the genus Chorioptes the suckers of the legs are borne on quite short unsegmented peduncles (fig. 2 a); the abdomen of the male terminates in paired lobes bearing hairs, two of which 
on each lobe, placed close together, are very wide and flattened (spatulate) (fig. 6).

The forms of Chorioptes are principally found on domestic animals, viz., on horses, cattle, sheep, and goats. The author found specimens of Chorioptes on the feet of a Huanaco which died in the Zoological Gardens, London, July, 1918. The forms of Chorioptes are so similar that they probably belong to a single species, of which they may be considered to be physiological varieties (like the forms of Sarcoptes and Psoroptes communis), which, although structurally alike, show a marked preference for their own animal host.

Chorioptic, or symbiotic mange as it is more commonly called, is usually restricted to the feet or to the base of the tail and anal fossa in cattle. In some cases it spreads on to the neck and back, or on to the belly, perineum, etc. This mange is usually of a mild type, however, remaining localised and spreading but slowly. Symbiotic mange in the horse is dealt with on page 34 .

\section{Genus Otodectes, Canestrini, 1894.}

Very like Chorioptes, the suckers of the feet being borne on short unsegmented peduncles as in that genus; but the posterior lobes of the body of the male are much less salient, and the hairs on them are not spatulate.

The mites of the genus Otodectes live in the ears of dogs, cats, and ferrets. They are usually considered to be varieties of a single species (Otodectes cynotis, Hering), but apparently do not differ from one another structurally. Otodectes cynotis, var. felis, Huber, 1861, is a very common parasite of London cats, and the otitis caused by it is usually known as canker. A little olive oil mixed with flowers of sulphur or a tenth part of naphthol should be poured into the ears every few days until a cure is effected.

Dogs used in hunting are especially liable to this kind of otitis (0. cynotis var. canis (fig. 7)), which sometimes is the cause of fits very similar to those due to epilepsy. The shape of the ear may be altered by constant shaking, the lower lobe becoming much thickened.

A warm solution of potassium sulphide (10 grams in a litre of water) should be poured twice daily into the ears of dogs suffering from parasitic otitis, and a cure will be effected in a few days. Before treatment the ears should be thoroughly cleansed, all visible waxy secretions being removed. Infected dogs should be isolated and the kennels disinfected. 


\section{4 \\ Mites Injurious to Domestic Animals.}

Genus Sarcoptes, Latreille, 1806.

Dorsal surface furnished with characteristic sharply pointed (dentate) scales and also with symmetrically arranged rod-like setae posteriorly.

Mites of the genus Sarcoptes are parasitic on a fairly large number

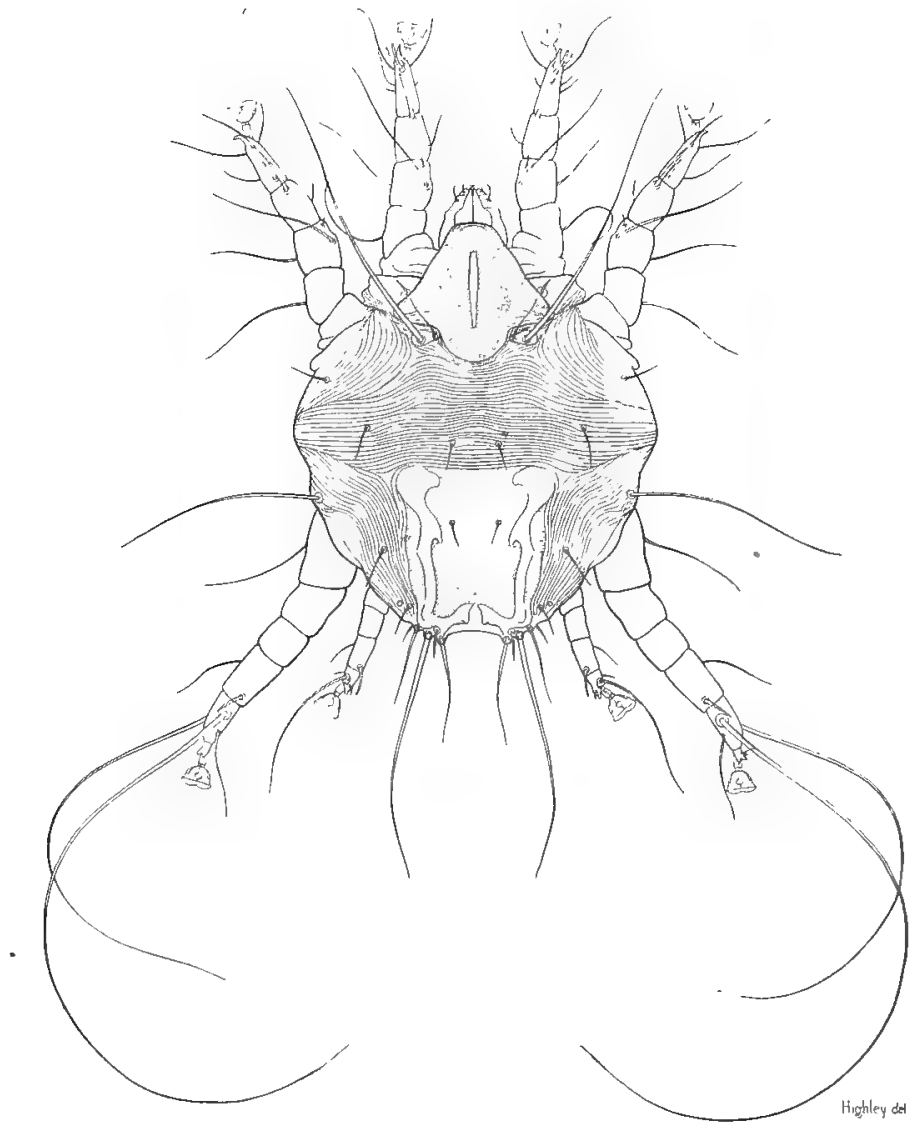

Fig. 7.

Dorsal view of male of Otodectes cynotis, var. canis, $\times 125$. (Original.)

of hosts, probably including all the domestic animals (mammals), but specimens found on different hosts are remarkably similar in structure. The author has examined examples of Sarcoptes from man, horses, cattle, sheep, goats, pigs, lions, wolves, dogs, foxes, 
coatimundi, hartebeest, kudu, guinea-pig, and rabbit without being able to find a constant morphological character by which they could be satisfactorily distinguished from one another.

The skin complaints induced by the various forms of strupcoptes occurring on domestic animals are briefly described below.

For the sake of convenience the three principal kinds of mange in the horse due to Sarcoptid mites are placed together, see page 34.

Sarcoptic Mange of the Dog.--Sarcoptic mange is apparently less common in dogs than the mange due to Demodex, but is more frequently met with in some countries than others. It is very much easier to cure than demodectic mange. Apparently the mange caused by Sarcoptes can make its appearance on any part of the body, but most frequently commences on the head. It spreads rapidly, and in a few weeks large areas of the skin may be invaded by the parasite. The symptoms are very like those of demodectic mange. There are reddish spots rather like flea bites, and the scratching of the animal causes reddish places and papules to appear. The infected part often becomes dry and covered with yellowish crusts. The hair falls out and the skin becomes thickened, wrinkled and creased. Pruritus is intense. Sarcoptic mange is easily confused with the mange caused by Notoedrus cuti and by Demodex, and also with several other skin complaints such as eczema, etc. The presence of the parasite is the chief distinctive feature.

A number of cases of human beings becoming infected with the Surcoptes of the dog (Sarcoptes scabiei, var. canis) have been recorded.

Sarcoptic Mange in Cattle.-- The sarcoptic mange of cattle has been very prevalent in some areas in the United States, and is usually treated by four dippings in lime sul phur, the interval between the dippings being from six to ten days. This kind of mange in cattle has also been a great nuisance in Alberta and Saskatchewan, where it has been combated by dipping, movement of cattle in the infected areas being prohibited, except when they are destined for immediate slaughter. In Britain, sarcoptic mange in cattle seems quite common in Scotland, and also occurs at Liverpool, and doubtless in other areas. Milkers often contract sarcoptic mange from cows, the arms, chest, and neck being affected. The complaint is known as "dairyman's itch."

Sarcoptic Mange in Pigs.--In pigs sarcoptic mange usually starts on the head, especially round the eyes and ears, but the back, 
sides, and inner surface of the thighs may also be invaded; sometimes the infection is general, the whole body being affected. Pruritus is intense even in the early stages. The hair falls out, and the skin becomes coated with dried crusts formed by the morbid secretions. Sometimes the papillae of the skin become increased

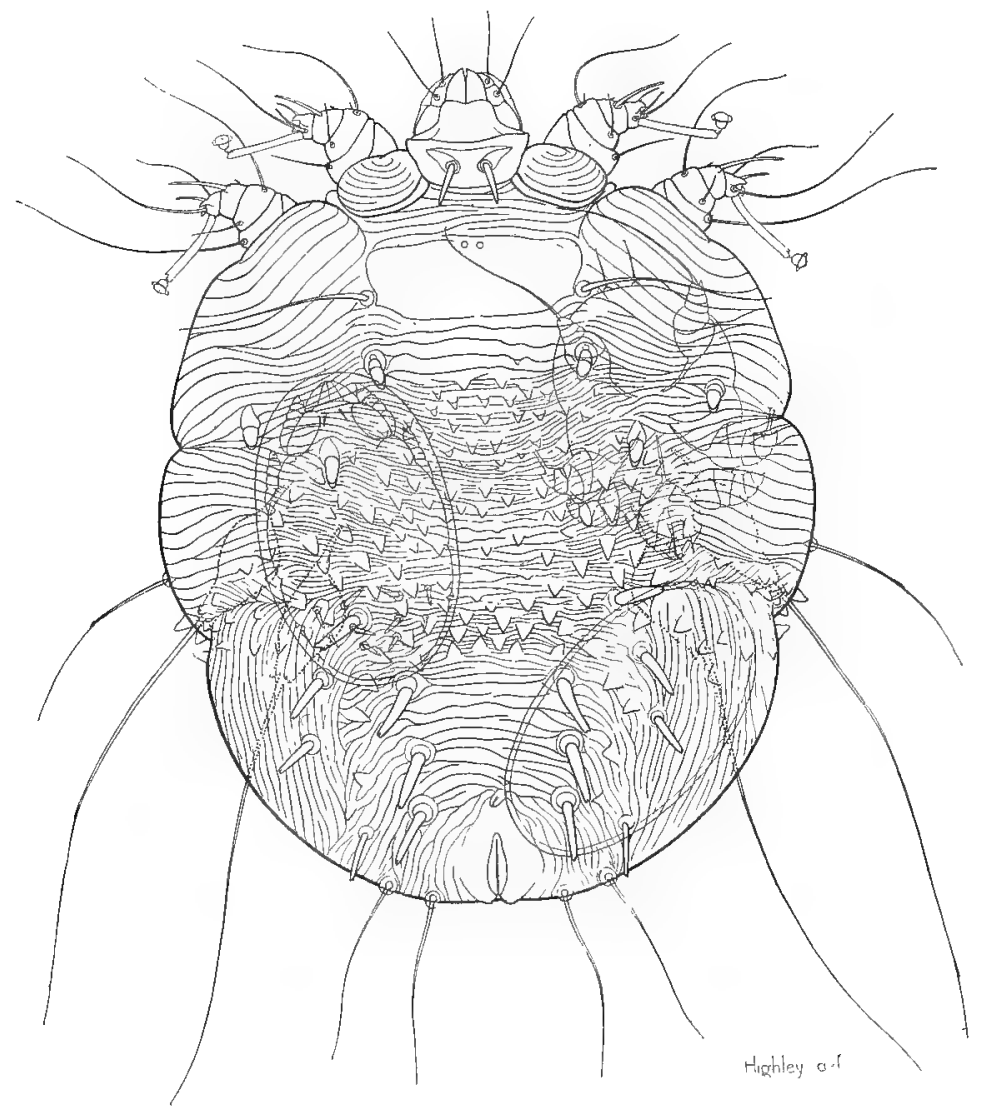

FIG. 8.

Sarcoptes scabiei, var. equi, $\& .-$ Dorsal view, $\times 209$. (Original.)

in size, forming wart-like eminences. In advanced cases the skin is very much thickened, wrinkled, and covered in places with thick crusts in which the specimens of Sarcoptes may be present in large numbers. This kind of mange is said to be more common in pigs in the United States than the mange due to Demodex. 
If only a few animals have to be treated, crude petroleum applied with a brush, mop, or cloth is a valuable remedy. Wallows medicated with crude petroleum, and dipping either in water and crude

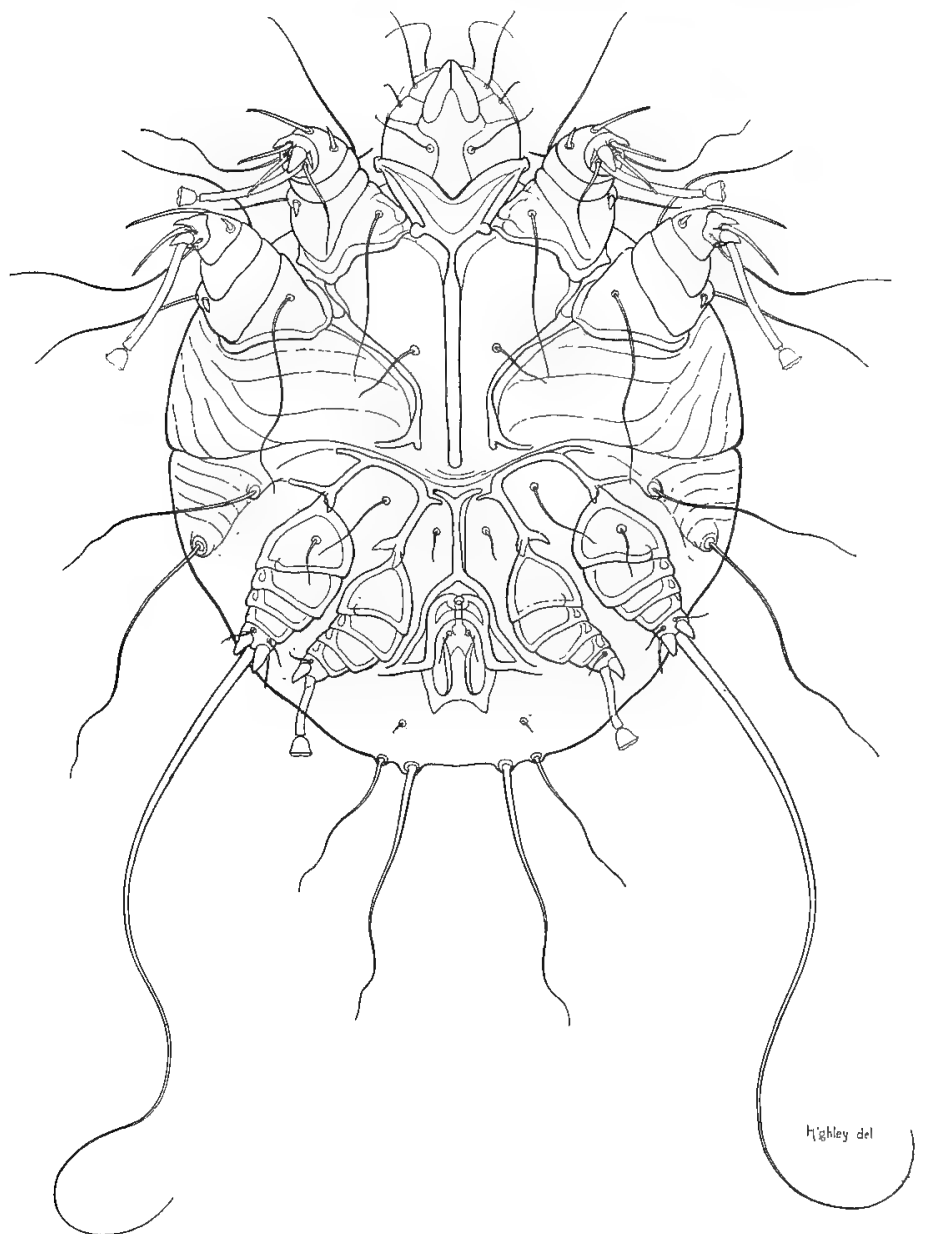

FIG. 9.

Sarcoptes scabiei, var. equi, o. - Ventral view, $\times 312$. (Original.)

petroleum or lime sulphur are much preferable, especially when large numbers of pigs have to be treated. When the lime sulphur dip is used, four or five dippings with an interval of five or six days between them are necessary. For further details concerning mange 
in pigs and its treatment, see Farmers' Bulletin, no. 1085, U.S. Dept. of Agriculture, by Marion Imes.

Sarcoptes scabiei, var. suis, is transmissible to man.

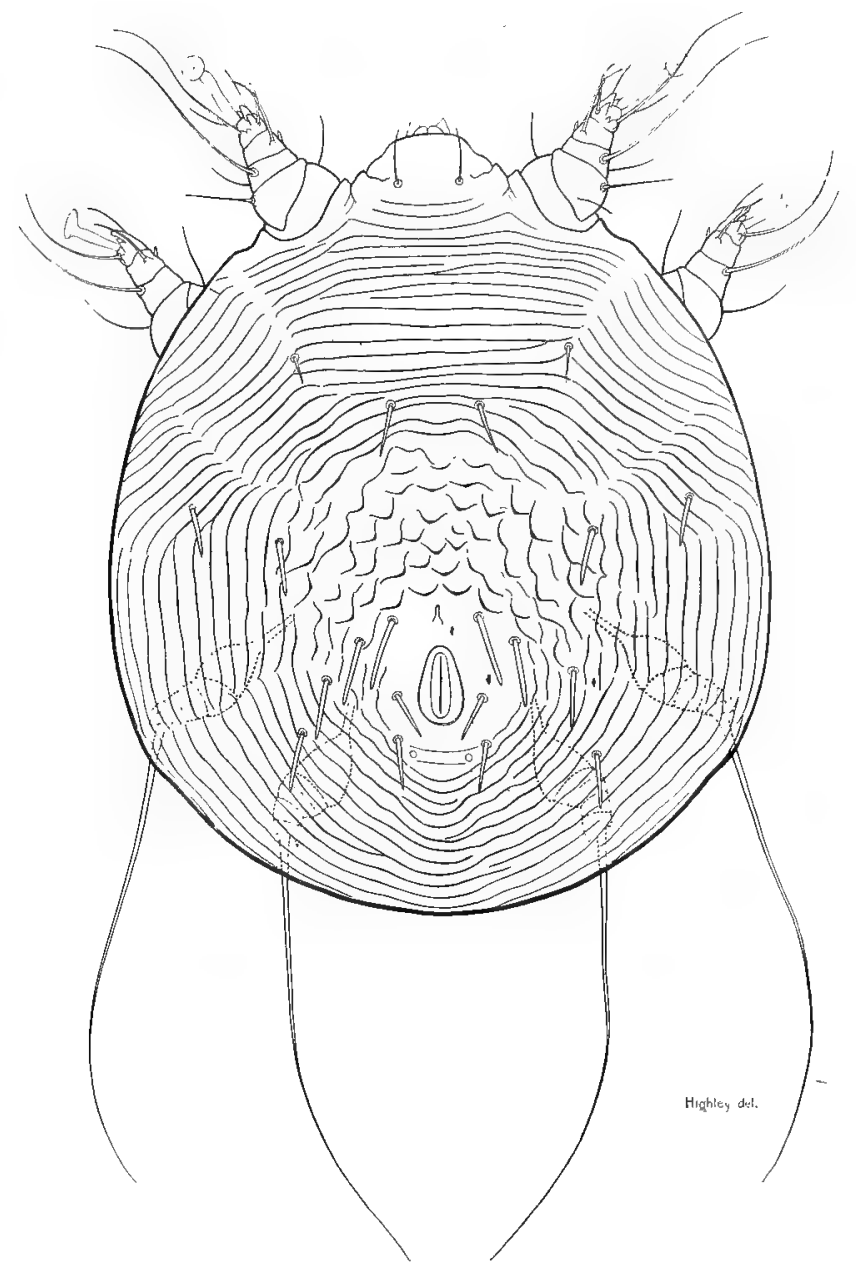

FIG. 10.

Notoedrus cati, var, cuniculi (p. 50). - Dorsal view of female, $\times 360$. (Original.)

Sarcoptic Mange in Sheep.-In sheep sarcoptic mange is usually confined to the head. It is only in advanced cases that the limbs and more rarely the body become affected. The disease does 
not spread to the woolly parts of the body. It occurs, however, in a generalised form in the Algerian and Tunisian breeds of sheep, also sometimes in Southdowns, Neapolitan sheep, etc. The Sarcoptes of the sheep (Sarcoptes scabiei, var. ovis, Mégnin) has been transmitted to goats.

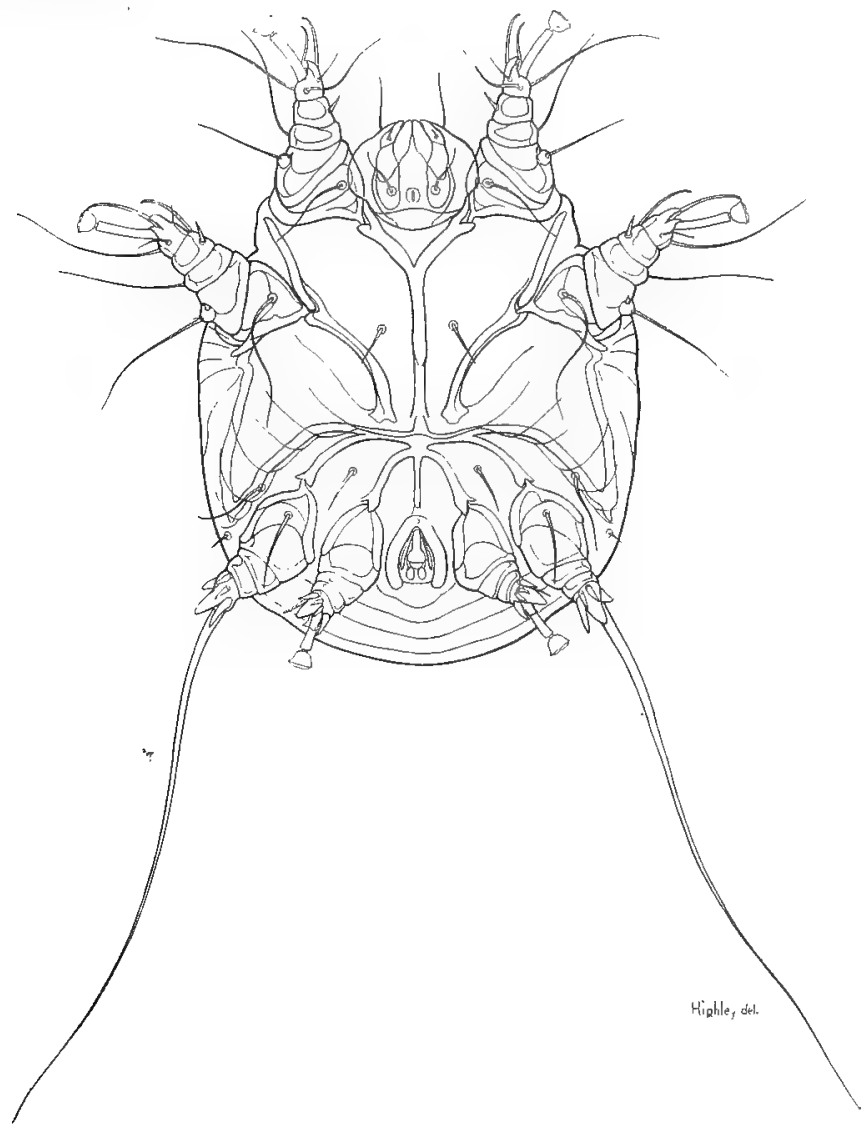

FIG. 11.

Notoedrus cati, var. cuniculi (p. 50).-Ventral view of male, $\times 370$. (Original.)

Sarcoptic Mange of the Goat.- The kind of sarcoptic mange found on goats is said to commence on the head and ears, afterwards reaching the body and limbs. Dry crusts are formed on the surface of the skin which, in advanced cases, becomes thickened, folded, and sometimes cracked, whilst the hair falls out. Pruritus is intense. 
The health of the goats suffering from this kind of scabies is sometimes greatly affected; they become thin, and death frequently ensues. The Sarcoptes of the goat (Sarcoptes scabiei, var. caprae, Fürstenberg) can be transmitted to man, and also to horses, sheep, cattle, and pigs.

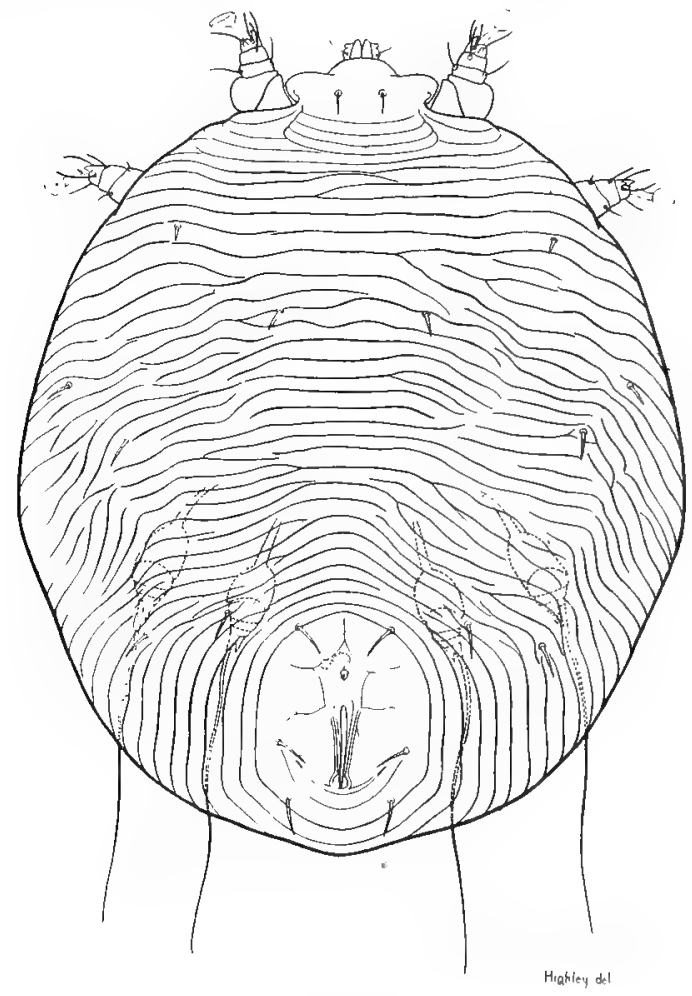

FIG. 12.

Notoedrus muris, parasitic on brown rat (p. 51).-Dorsal view of female, $x 230$. (Original.)

Sarcoptic Mange in Camels and Dromedaries.-Sarcoptic mange is a very common disease of camels in Egypt and other parts of North Africa, and causes serious Iosses if neglected or improperly treated. If not treated, F. E. Mason says the disease makes rapid progress and may extend to the whole body. Later the skin becomes thickened, wrinkled, and covered with thick crusts. When the disease reaches a more advanced stage the camel 
becomes emaciated, the crusts increase in thickness and extent, whilst ridges appear on the skin, which is cracked and ulcerated. A very offensive fluid is discharged by the cracks and ulcers, the limbs become swollen, etc. The working capacity of camels suffering from scabies is much reduced, and death may finally take place through exhaustion or from complications with other diseases. The variety of Sarcoptes scabiei found on camels is transmissible

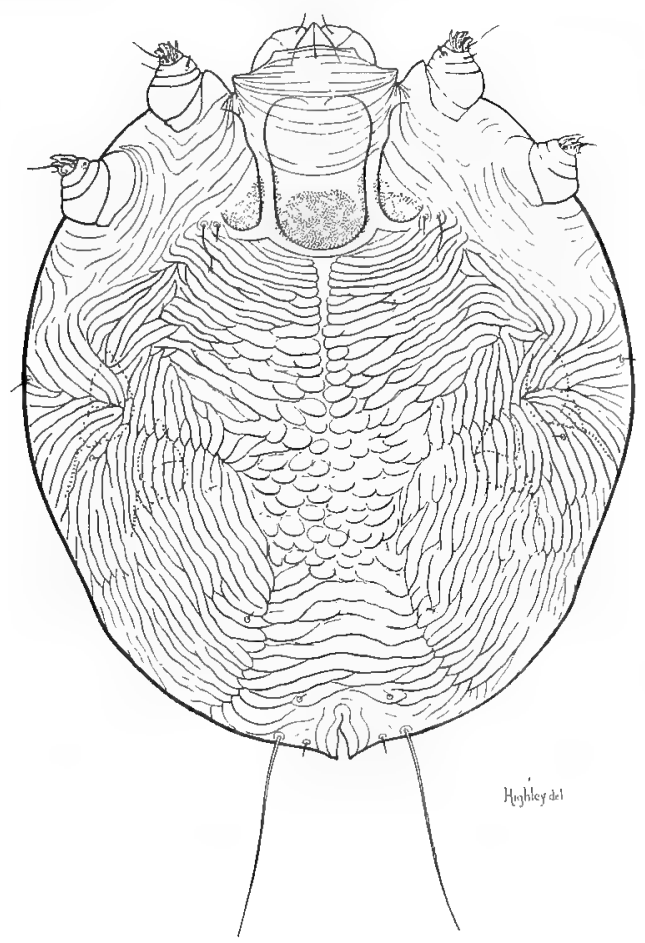

FIG. 13.

Cnemidocoptes mutans. - The mite of scaly-leg in fowls (p. 51). Dorsal view of female, $\times 174$. (Original.)

to man and also to horses. Mason has used colocynth tar (distilled from the seeds of (itrullus colocynthus) successfully against sarcoptic mange in camels, and also in sarcoptic and psoroptic mange in horses, and against ticks. Before applying this remedy, the camel should be clipped, washed with soft soap, and the crusts scraped off with a blunt knife.

Ointments with a fatty basis are apt to become rancid in hot 
climates and may cause blisters. For this reason, Curasson recommends an ointment, or rather paste with a white soap as a basis, for treating dromedaries suffering from scabies. Soap shavings (600 grams) are dissolved in one litre of warm water, after twenty-

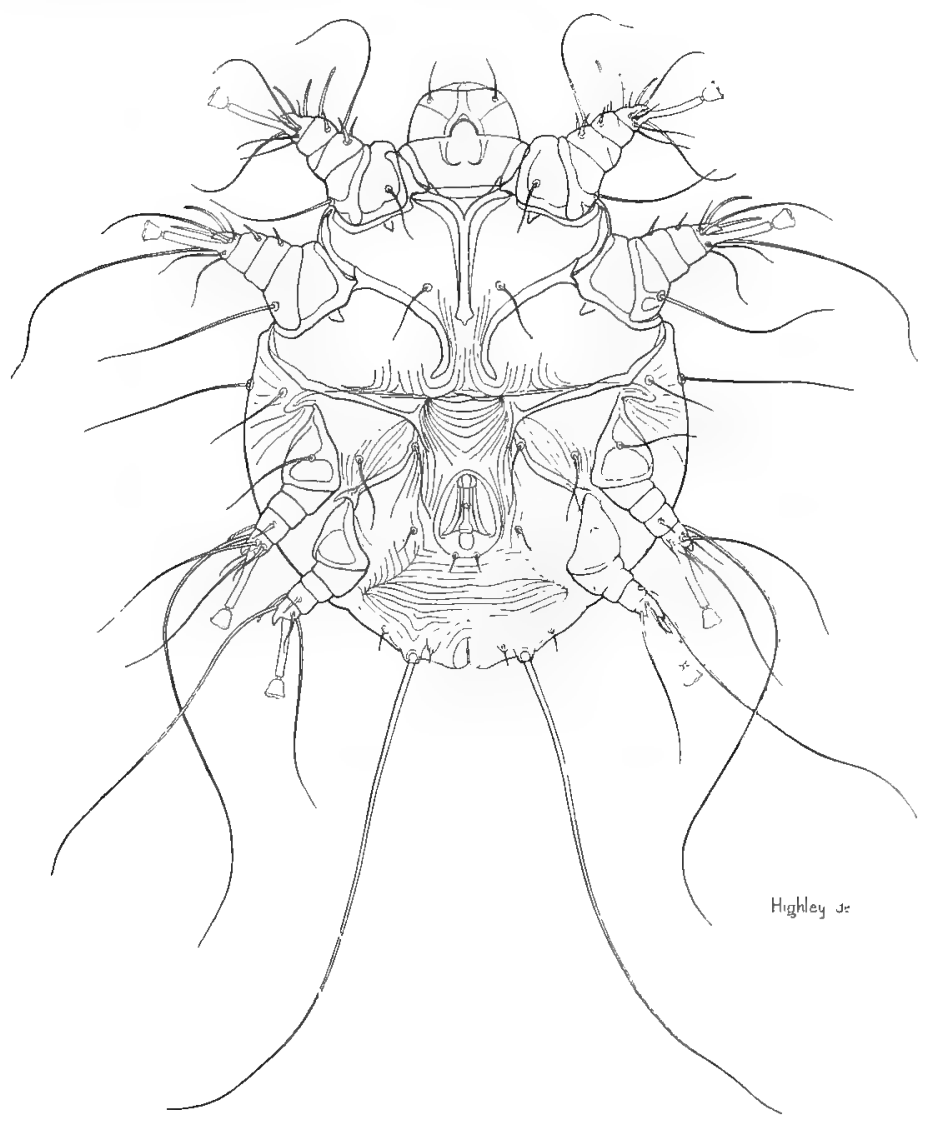

FIG. 14.

Cnemidocoptes mutans (p. 51).-The mite of scaly-leg in fowls. Ventral view of male, $\times 305$. (Original.)

four hours 300 grams of flowers of sulphur are added, finally 200 grams of cresyl and 150 grams of petrol are slowly poured in, the mixture being gently stirred meanwhile. The resulting paste is applied with a brush or by hand and is well worked in with the finger tips. Next day some of the paste will be found at the end of the 
hairs and should be rubbed into the skin again. On the sixth day the parts treated should be cleansed with a brush and tepid water.

Sarcoptic Mange of the Rabbit.-Rabbits sometimes suffer from sarcoptic mange, besides being liable to notoedric mange and to otitis due to the presence of Psoroptes. In rabbits sarcoptic

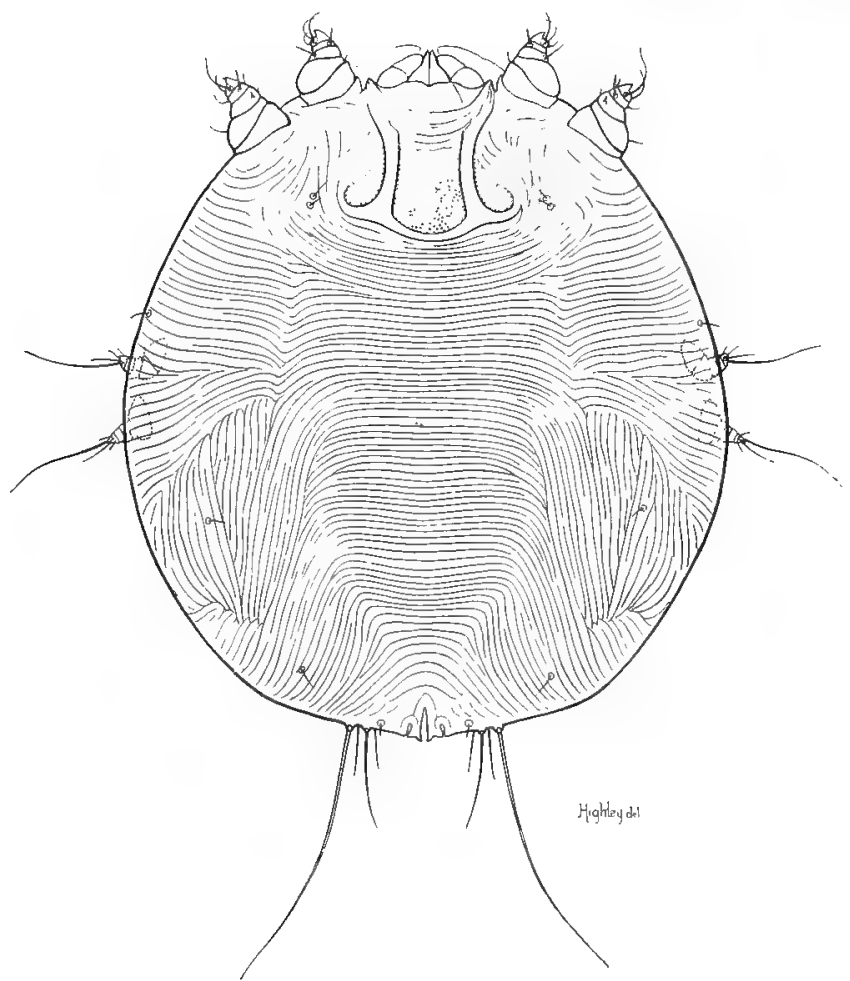

FIG. 15.

Cnemidocoptes laevis, var. gallinae (p. 54).-The mite of Depluming Itch in fowls. Dorsal view of female, $\times 210$.

mange affects much the same regions as the notoedric kind; the legs are, however, first attacked, then the tip of the nose, which may be transformed into a kind of proboscis. From the nose the mange spreads on to the face and ears, and sometimes on to the body. Greyish or yellowish crusts are present on the diseased parts. This kiad of mange may cause great mortality. Railliet 
and Henry state that treatment is easy; much washing and bathing should be avoided; the fur on the affected parts should be cut and the crusts well rubbed with black soap; the diseased places should then be washed, carefully dried, and treated with some suitable ointment.

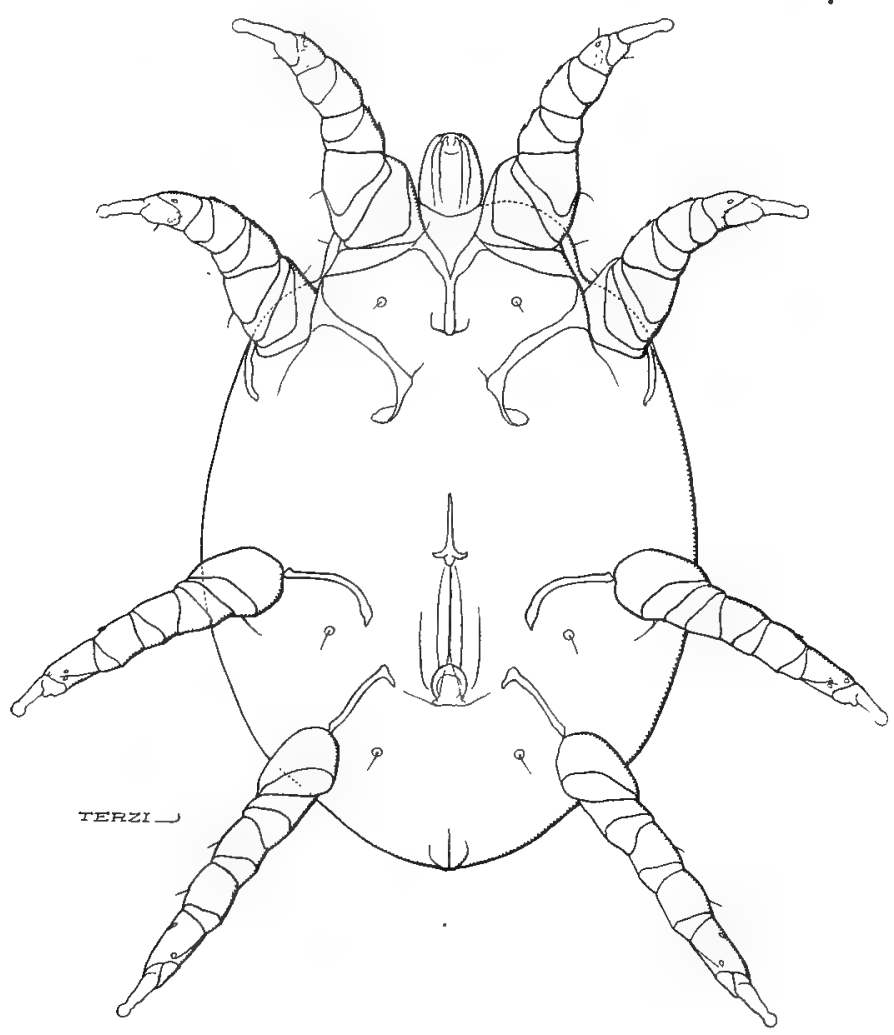

FIG. 16.

Cytoleichus nudus (p. 59).-An internal parasite of the domestic fowl. Ventral view of female, $x 136$. (Original.)

The variety of Sarcoptes found on the rabbit can be transmitted to the guinea-pig and ferret.

Mange in Horses.-Horses suffer from three different kinds of mange, viz., the sarcoptic (sometimes called scabies), psoroptic, and chorioptic (or symbiotic). The first of these is much the 


\section{Mites Injurious to Domestic Animals.}

most serious owing to the burrowing habits of the parasites, which make it difficult to reach them with acaricidal solutions. Mange in horses is very common in war time, great numbers of animals being affected, whilst it is comparatively rare in normal times. All newly

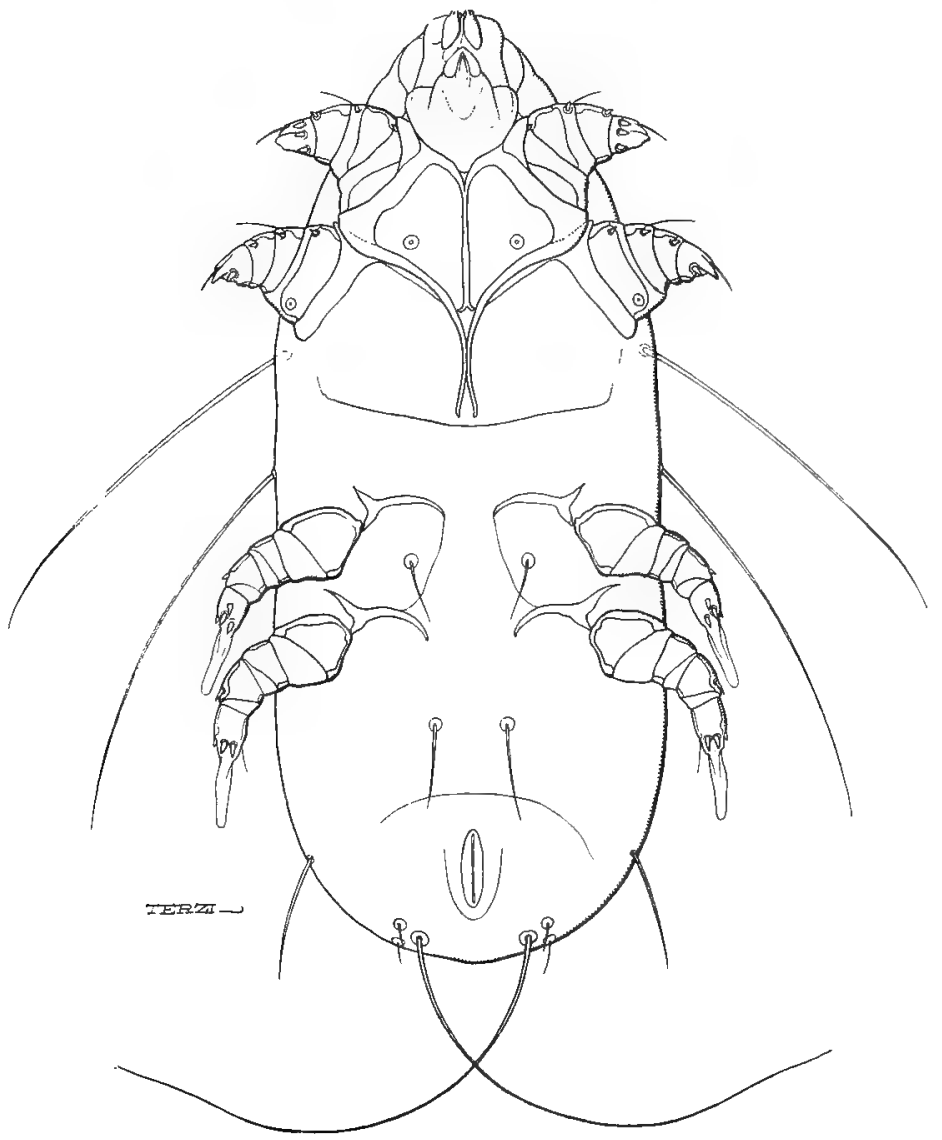

FTG. 17.

Laminosioptes cysticola (p. 59).-An internal parasite of the domestic fowl. Ventral view of female, $\times 376$. (Original.)

purchased animals should be carefully examined for symptoms of mange.

Sarcoptic mange commences by little circular hairless places and small elevations, accompanied by intense itching; these little 
elevations can sometimes be felt if the hand is passed over the skin. Horses suffering from this kind of mange try to rub themselves against any suitable object, and bite those parts of the body

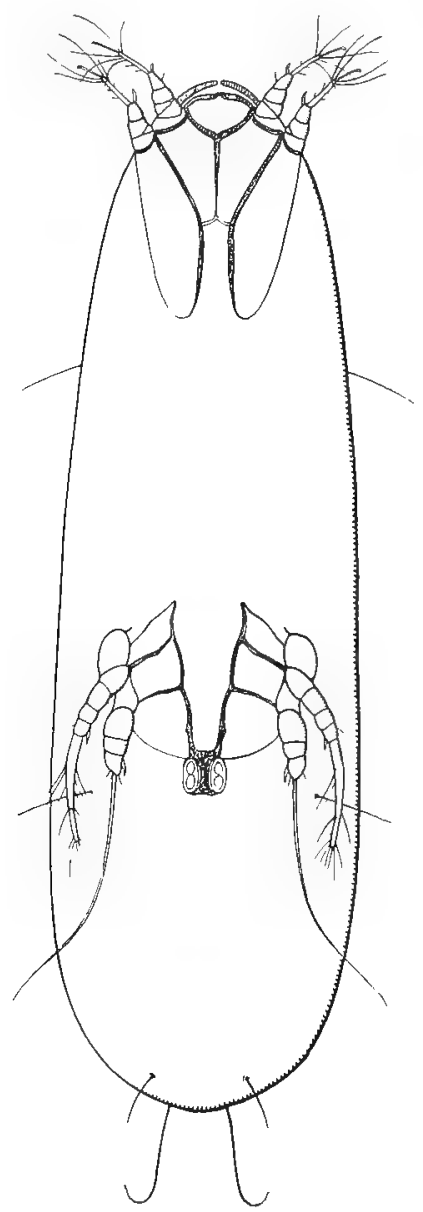

FIG. 18.

Hypopial nymph ("Hypodectes") of Fraculifer rostratus (p. 63); from pigeon, $\times 80$. (After Neumann.)

which they can reach. When the affected parts of the body are scratched with the hand the animal shows signs of pleasure, moving the end of the nose in a characteristic manner. Any part of the body may be attacked, but those parts which come in contact with 
the saddle or-harness are usually affected first. The disease often commences on the withers, spreading afterwards on to the back and sides. The hair is thin and broken in the rubbed parts of the

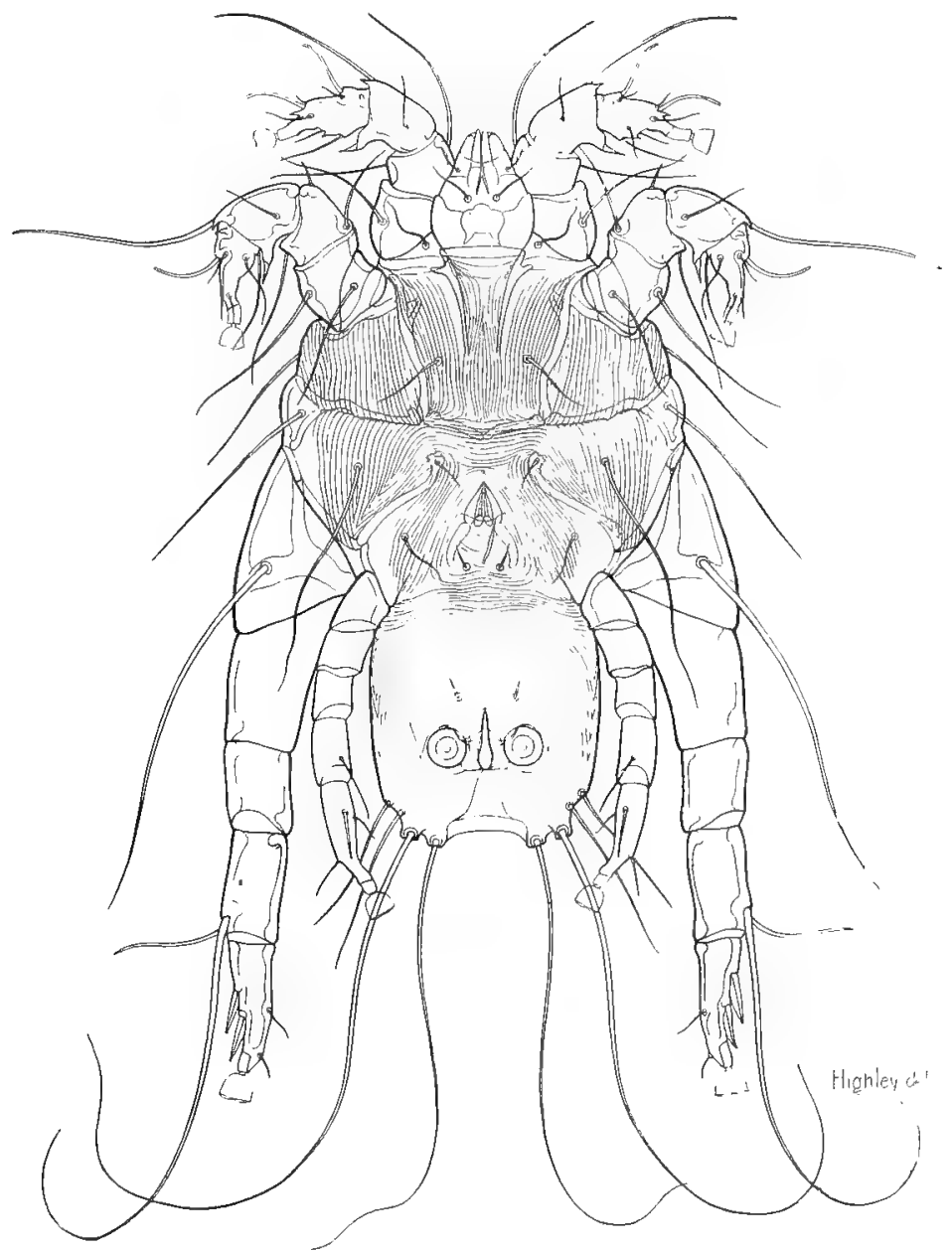

FIG. 19.

Megninia sp. (p. 63)-From domestic fowl, in North America. Ventral view of male. (Original.)

body, and abrasions or excoriations may be present. In advanced cases the skin is hard and folded, and the animals become very thin and may die of exhaustion. 
Under war conditions, according to Fayet, sarcoptic mange of the horse commences on the forehead, parotid regions, base of the ears, cheeks, intermaxillary spaces, etc., and may be localised for some time in these regions and on the forequarters. If treated promptly at this stage the disease can be prevented from invading

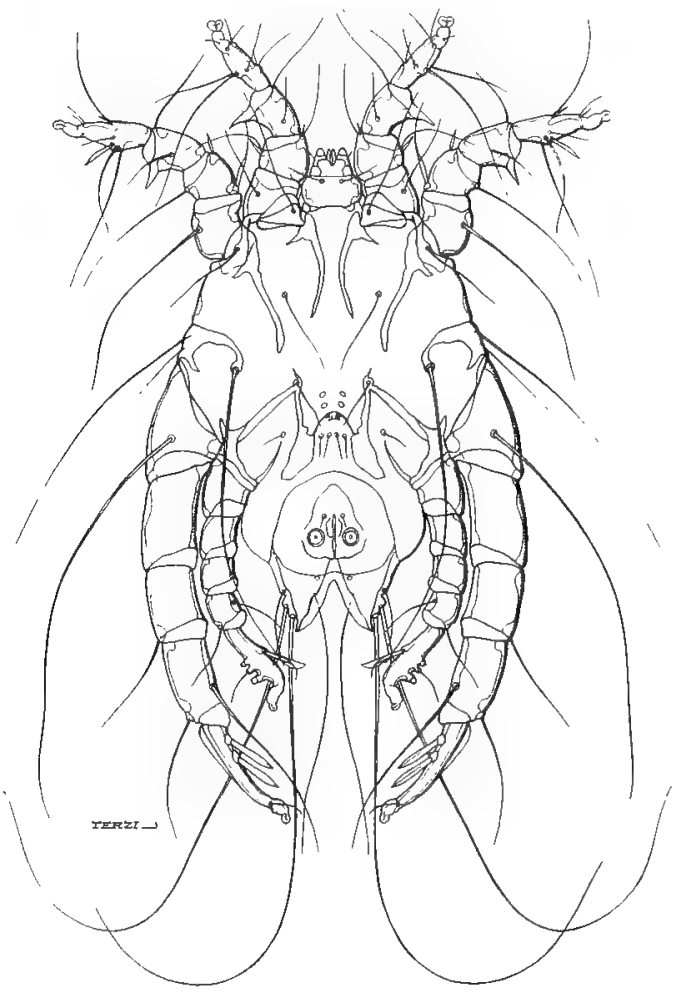

FIG. 20.

Megniria columbae (p. 64).-From domestic pigeon. Vextlal view of male, $\times 154$ (Original.)

other parts of the body. Close clipping enables mange to be readily detected.

Mr. A. W. Nöil Pillers (Notes on Mange, and allied Mites, for Veterinarians, London, 1921) states that sarcoptic mange can be distinguished clinically from other types of mange with a fair degree of accuracy. He says that " the lesion prefers the thinner-skinned areas; in addition to encrustation the skin itself is thickened, the 
lesion is diffuse, with intermingling of areas containing hair, and there are here and there numerous blood points. Early cases are difficult to diagnose as there are only a number of pimples, diffusely scattered without loss of hair and which give a positive labial reflex when the part is rubbed." Mr. Pillers affirms that there is a marked seasonal prevalence in sarcoptic mange, the disease being usually at its lowest in warm weather and when there is plenty of sweating of the skin. There is a gradual increase during October, November and the following months, until in March it reaches its height. In the ensuing months it falls slowly, and from June to September
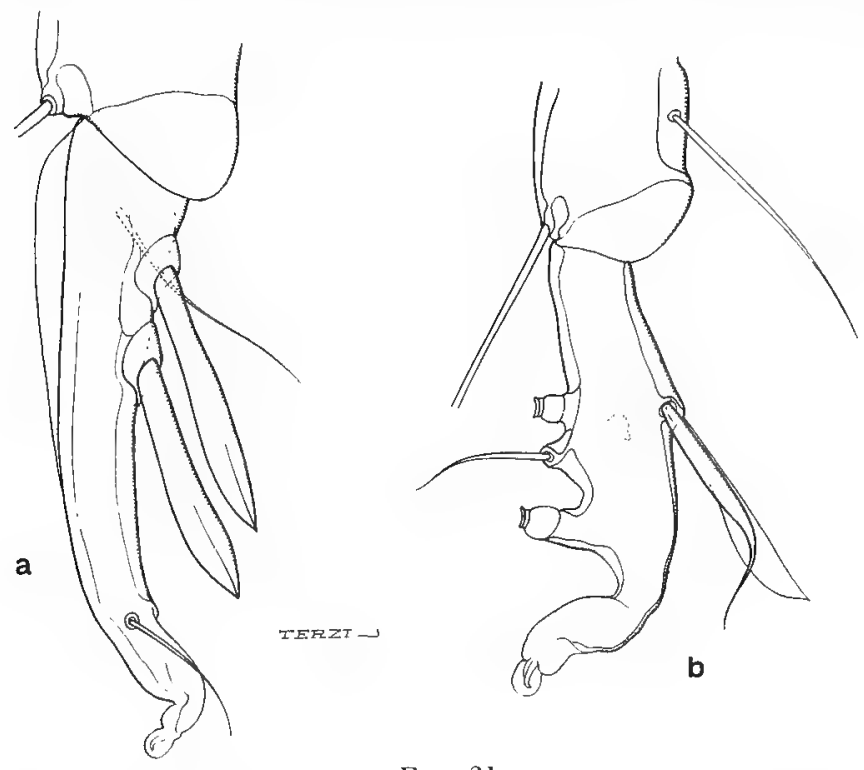

FIG. 21.

(a) Tarsus of fourth leg. (b) Tarsus of third leg, of male of Megninia columbae (p. 64), greatly enlarged. (Original).

the prevalence of sarcoptic mange is at its lowest. It may justly be said to be a disease of winter and long and dirty coats.

Sarcoptes can usually be found by soaking scrapings from the infected animal in 10 per cent. solution of caustic potash. Occasionally, however, it is difficult to find the mites, and it may be necessary to boil the material in the caustic potash and then centrifuge it: after a few turns of the handle of the machine the Acari are generally to be found at the bottom of the tube.

Sarcoptic mange should be treated at as early a stage as possible, 
and infected horses should be isolated from healthy animals. According to Moussu, horses which are slightly affected with seabies should be treated for at least two or three weeks if the cure is to be complete, and serious cases need at least from two to two and a half months. Treatment has to be very thorough, particular attention being paid to areas that are difficult to reach and nooks
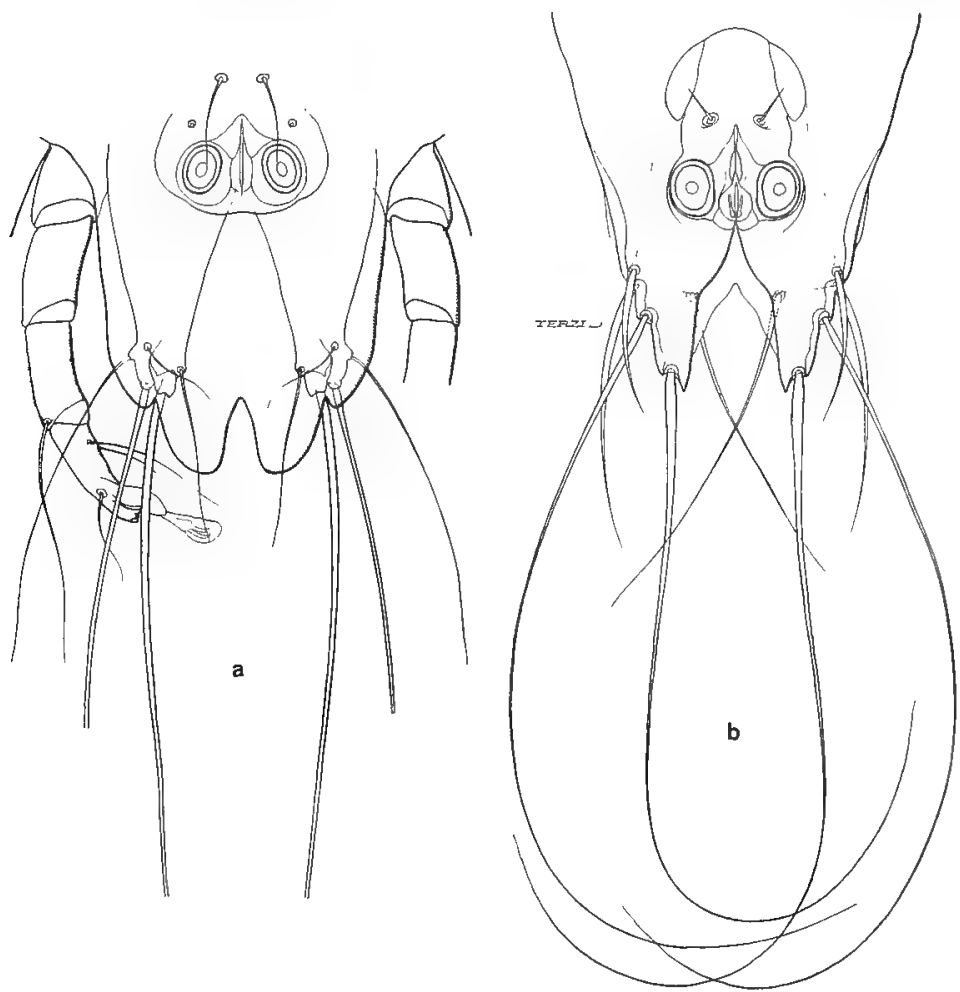

FIG. 22 .

(a) Posterior end of body of male of Megninia velata (p. 64).

(b) Posterior end of body of male of Megninia cubitalis, var. ginglymura (p. 64), from English turkey. (Original.)

and corners such as the base of the ears, inner surface of the limbs, belly, base of tail, etc., otherwise the disease is apt to reappear. Sulphurated oil is very useful as a remedy. It should be applied to every part of the body, not merely to the areas in which the mange is visible. A fresh application of the acaricidal mixture should be made every four days until the cure is effected. Spraying with lime 
and sulphur is recommended as a preventive and for affected horses by the Ministry of Agriculture and Fisheries (see Leaflet No. 274). Noël Pillers gives several formulæ for dressings, one of them being

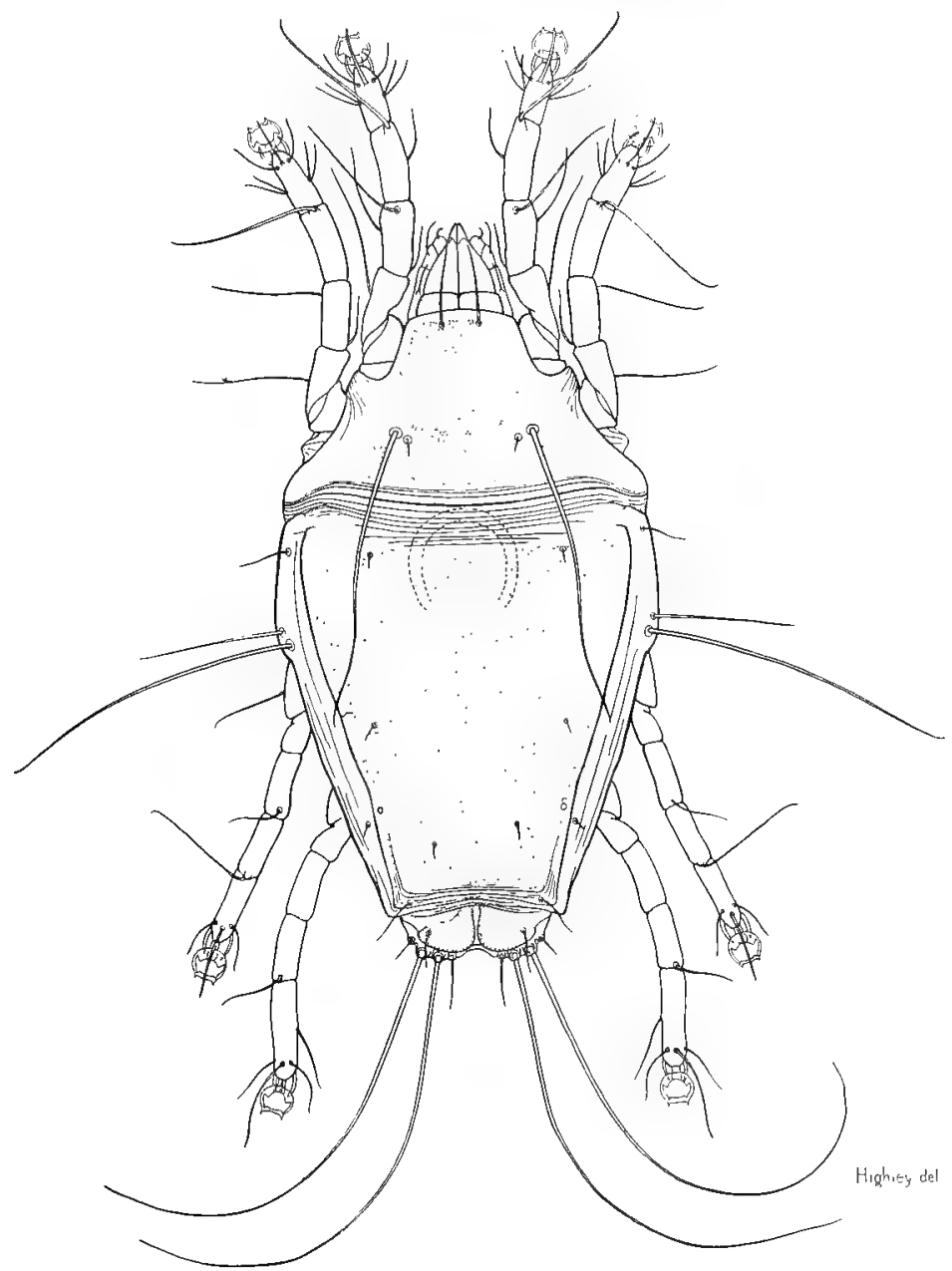

Fig. 23.

Pterolichus obtusus (p. 64), a feather mite from domestic fowl. Female from above, $\times 160$.

as follows :-Strong calcium polysulphide solution one part $=8 \mathrm{oz}$., water two parts $=16$ oz., horse fat two parts $=16 \mathrm{oz}$., total two pints. He says that the strong solution of calcium polysulphide may 
be prepared in small quantities by mixing $2 \frac{1}{4} \mathrm{lb}$. of sulphur with $1 \mathrm{lb}$. of good quicklime in a bucket, making into a paste, and boiling

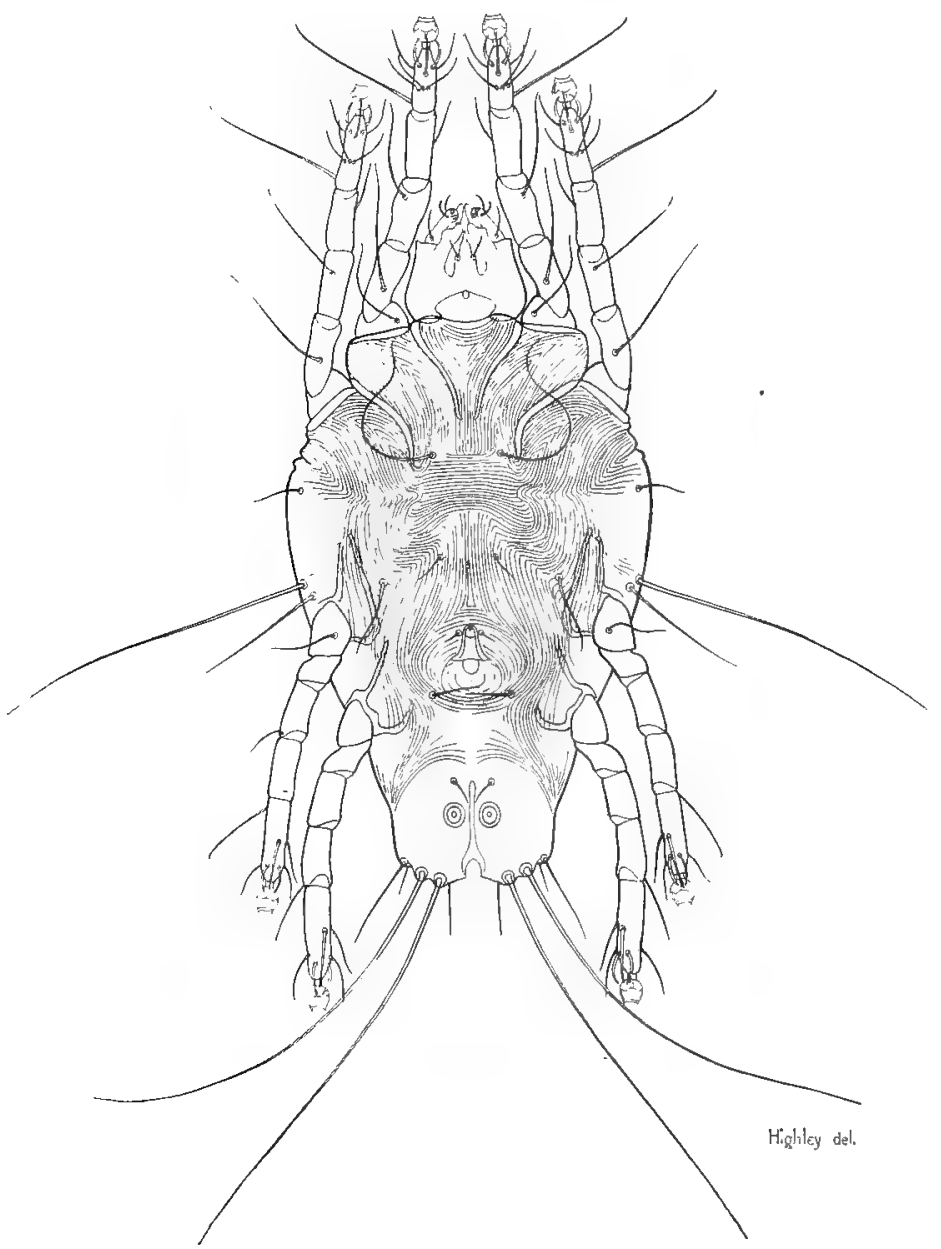

FIG. 24.

Pterolichus obtusus (p. 64), a feather mite from domestic fowl. Male from below.

in two gallons of water until a dark red-brown solution is formed. Boiling will take about three hours; the whole must be kept rell stirred during the process and made up to two gallons at the end. 
About two pints of this oily mixture will be sufficient to dress an ordinary case.

In war time dipping in specially constructed tanks is used against sarcoptic mange in horses, and is said to be much the best method of combating the complaint. Descazeaux gives a plan of a piscina or tank for bathing horses in Rec. Méd. Vét. D'Alfort, xciv., no. 12, June 30th, 1918, p. 273.

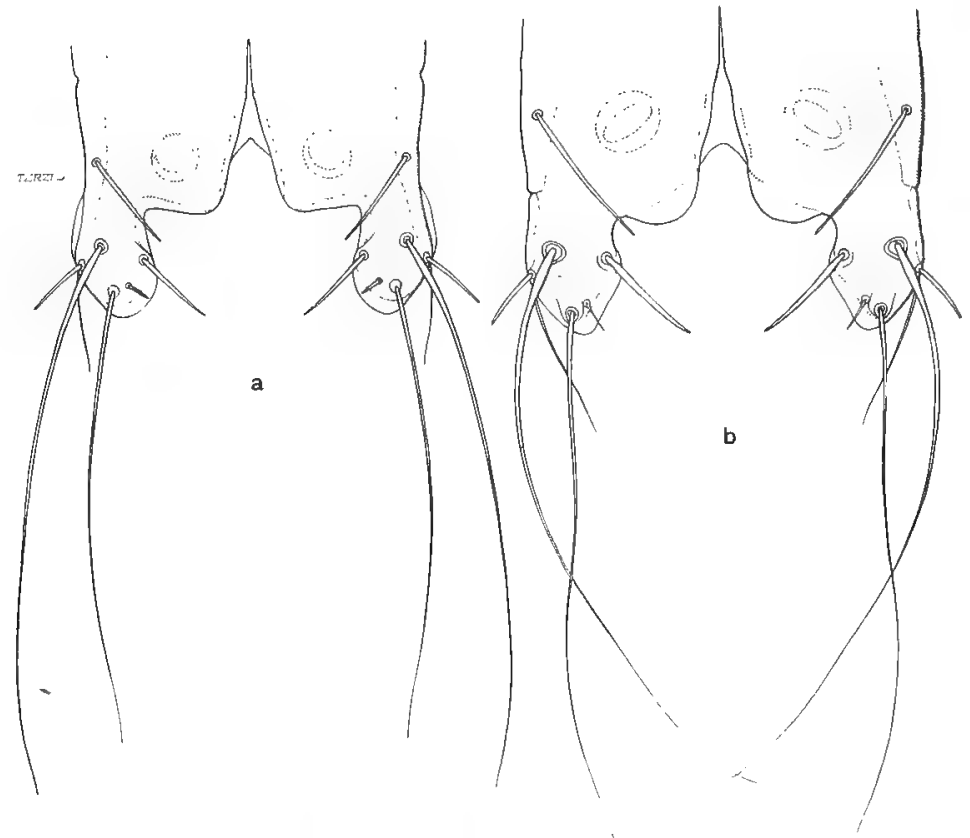

FIG. 25.

(a) Posterior abdominal lobes of male of Pterolichus bicaudatus (p. 64), a feather mite from ostrich. (b) Posterior abdominal lobes of Pterolichus sculpturatus (p. 64), from ostrich. (Original.)

Sarcoptic mange of the horse is transnissible to man.

Psoroptic mange in the horse chiefly affects the regions of the body situated near the long hair, such as the neck, withers, rump, base of tail, etc., but in advanced cases other parts of the body may be invaded. There is an accumulation of thick humid crusts under which the mites live and nultiply.

According to Railliet and Henry (Bull. Soc. Cent. Méd. Vet. Ixxiii., 1920, p. 41) the Psoroptes found in the ears of horses, mules and asses is distinct from that occurring on the body of these hosts. 
They consider the Psoroptes living in the ear to be a new species which they describe under the name $P$. hippotis. Only two of the longer hairs on the posterior abdominal lobes of the male of $P$. hippotis have their bases contiguous, whereas in $P$. communis, var. equi, three of these hairs originate quite close together, the bases of all three being contiguous and on the same level. It seems possible to the author that $P$. hippotis may prove to be identical with $P$. communis, var. cuniculi, or $P$. c., var. ovis, both of which have the hairs on the posterior abdominal lobes of the male disposed in a similar way (see text-fig. 3, b and c). Professor A. Henry states that

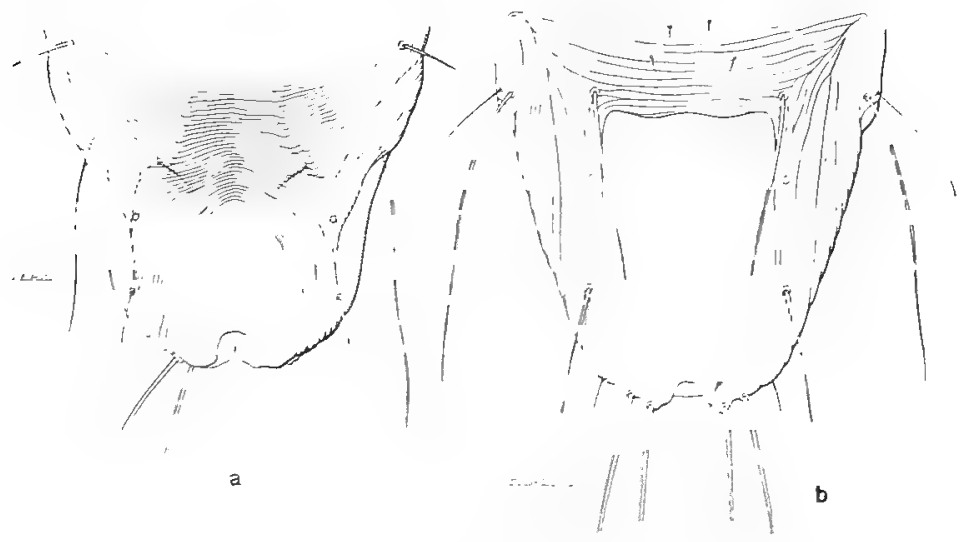

FIG. 26.

(a) Posterior end of nymph of Pterolichus bicaudatu.s (p. 64), from above, showing shape of dorsal shield. (b) Posterior end of nymph of Pterolichus sculpturatus (p. 64). (Original).

otocariasis due to Psrroptes is very common in the horse, sometimes heing present in 70 per cent. of the horses examined in France.

At the beginning of the great war all but a verr small percentage of the cases of mange were due to Psoroptes, but this complaint became quite rare later, and sarcoptic mange became prevalent.

Infection is spread through contact between diseased animals and also through contaminated harness, grooming implements, rugs, stable utensils, litter, etc. Anything that has come in contact with an animal suffering from mange may remain infectious for screral werkis; hence the need for cleanliness and disinfection with ersyl or cihrer suitable preparation.

liall sirterplir and psoroptic mange should be notified to an

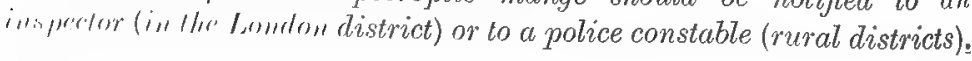


Chorioptic or symbiotic mange is usually confined to the lower part of the limbs and root of the tail. Sometimes this complaint causes horses to stamp when in the stable or to knock their fect together, and in doing this the coronets of the feet may be damaged.

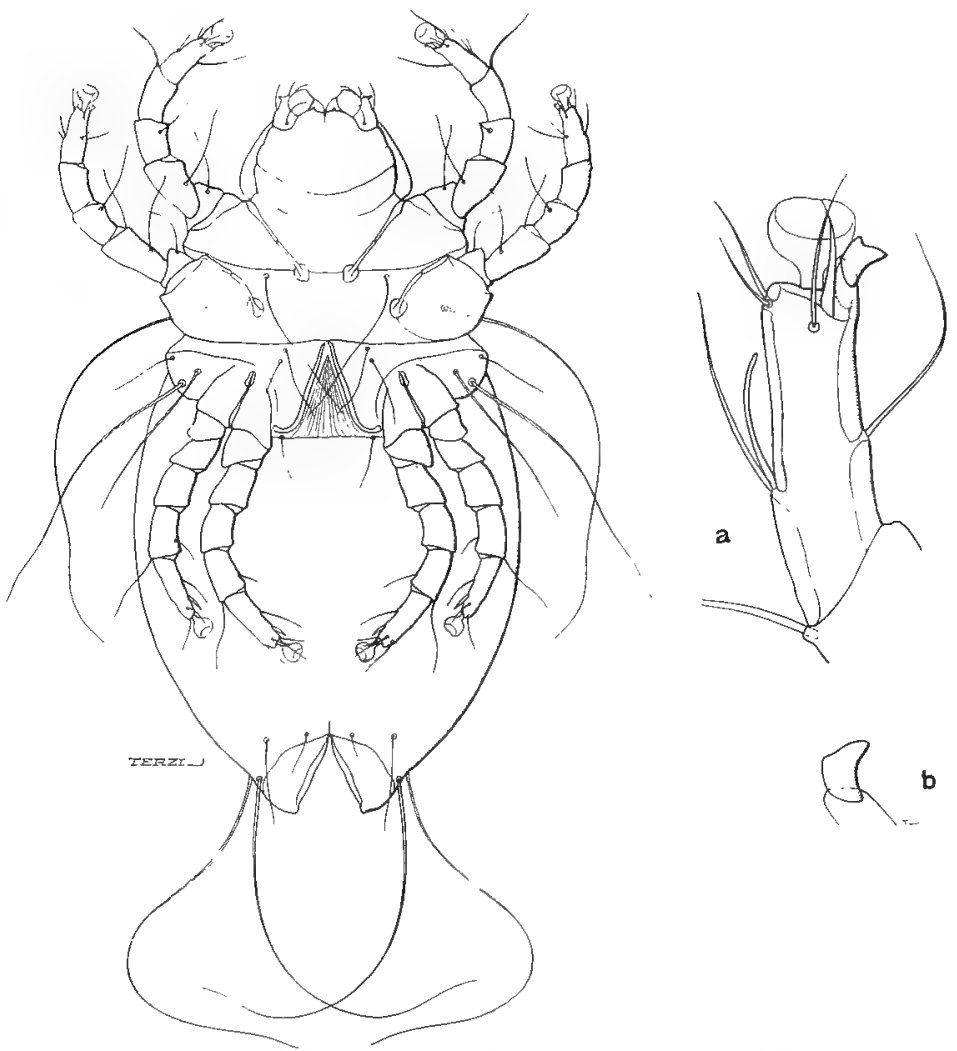

FrG. 27.

Pterolichus sp., from interior of quills of feathers of North American fowl, female from below, $\times 104$. (a) Tarsus of second leg of same greatly enlarged. (b) Denticle on first: tarsus very greatly enlarged. (Original.)

Leaflet No. 274, issued by the Ministry of Agriculture and Fisheries, should be consulted by those interested in parasitic mange in horses, asses, and mules. Remedies, symptoms, ${ }_{2}^{F}$ etc., will be found. in this leaflet. 
Besides the three kinds of mange described above, pruritus and other trouble nay be caused by Demodex (see page 80 ).

Genus Notoedrus, Railliet, 1893.

Very similar to Sarcoptes, but with the anus well on the dorsal

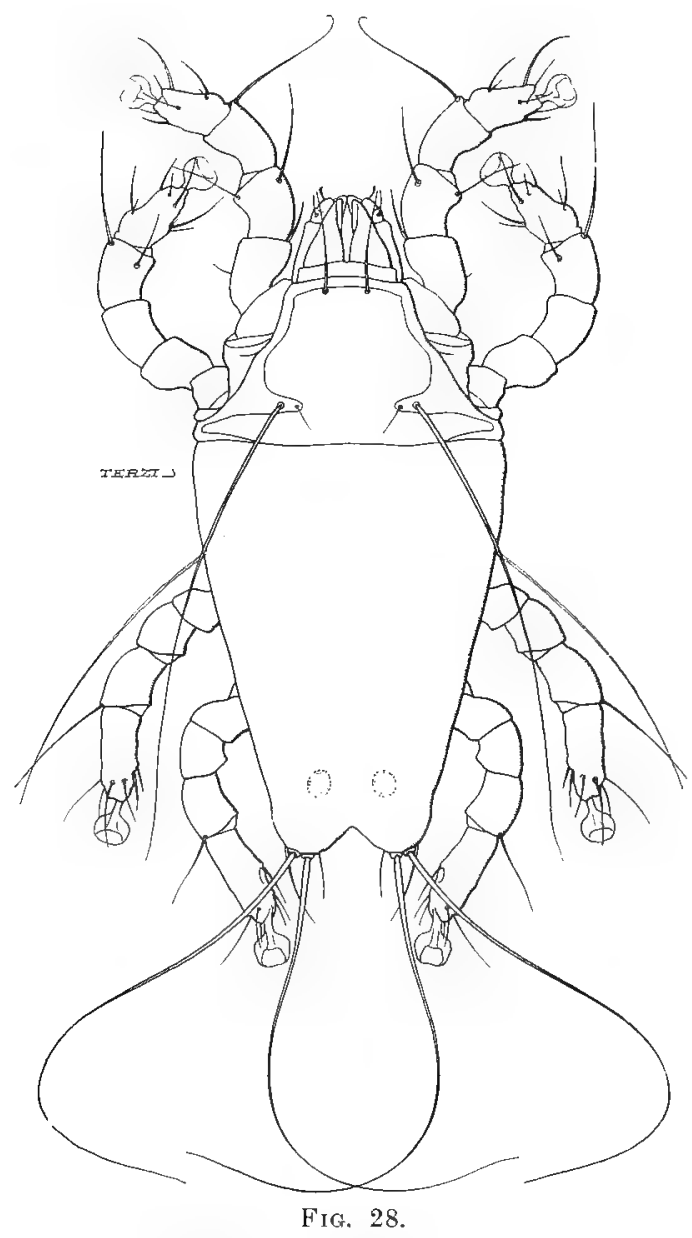

Pterolichus sp., from interior of quills of feathers of North American fowl. Male from above, $\times 216$. (Original.)

surface. This genus is not very distinct from Sarcoptes, and should perhaps be considered only a sub-genus. 
Notoedrus cati, Hering, 1838.

(Figs. 10, 11.)

There are a number of scales grouped together in the middle of the dorsal surface in this species, but they are not nearly so well developed as in the species of Sarcoptes, only the posterior'edge being somewhat salient.

Mange in Cats.-Mange in cats generally starts on the neck,

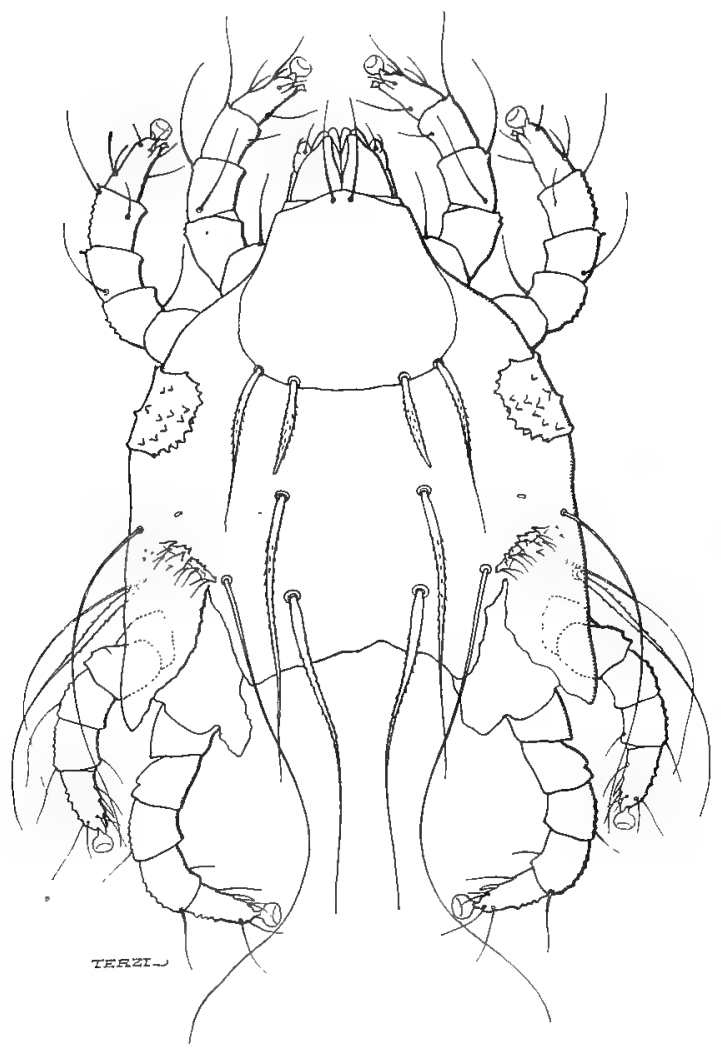

Fig. 29.

Pterolichus sp., from interior of quills of feathers of North American fowl. Cast skin of nymph, $\times 160$. (Original.)

afterwards appearing on the ears, forehead, and round the eyes; finally nearly all the head is affected. Greyish crusts are present, and in advanced cases the skin becomes hard, thickened, and creased, almost like leather in appearance. In cats mange is usually 
restricted to the head and neck, rarely extending to the body and limbs.

Craig has reported three cases in which this parasite of the cat was found in dogs suffering from mange. One of these animals was known to have associated with a cat affected with notoedric mange.

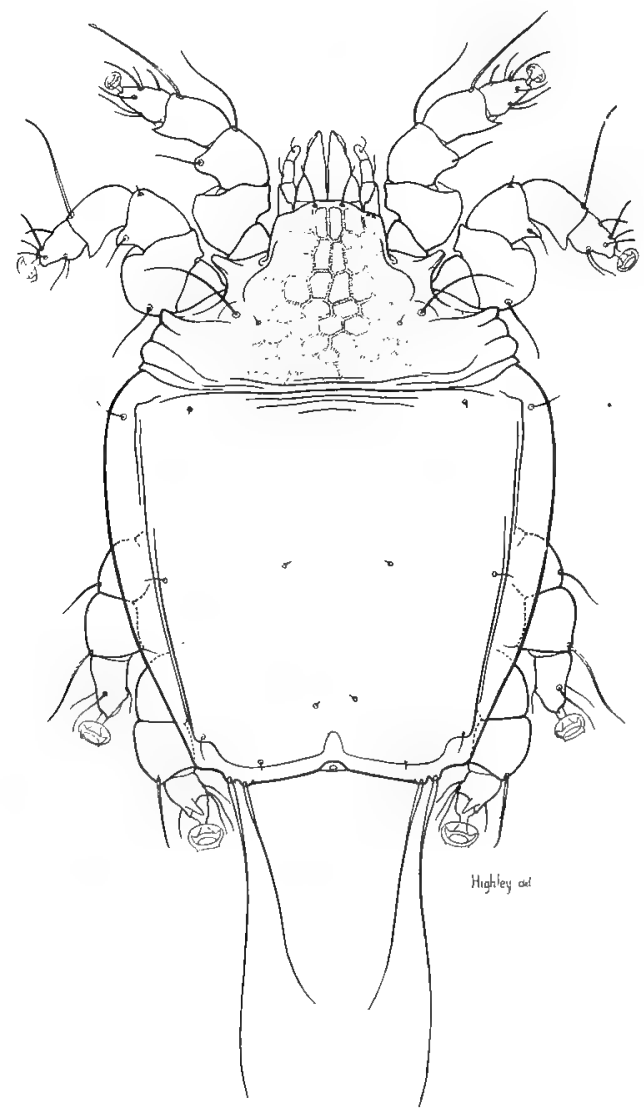

FrG. 30 .

Freyana chanayi (p. 64). Feather mite from domestic turkey, North America. Dorsal view of male, $\times 183$. (Original.)

The following case of mange in a dog caused by Notoedrus cati was observed by the author in July, 1917. The disease occurred in a puppy aged about three months, and there was no history, the animal being a stray one found in the streets of London. The 
symptoms were as follows:-The upper part of the face was badly affected, being greyish in colour and scabby, especially the forehead and round and between the eyes. A large part of the body was very seriously affected, the sides and belly being leathery and almost

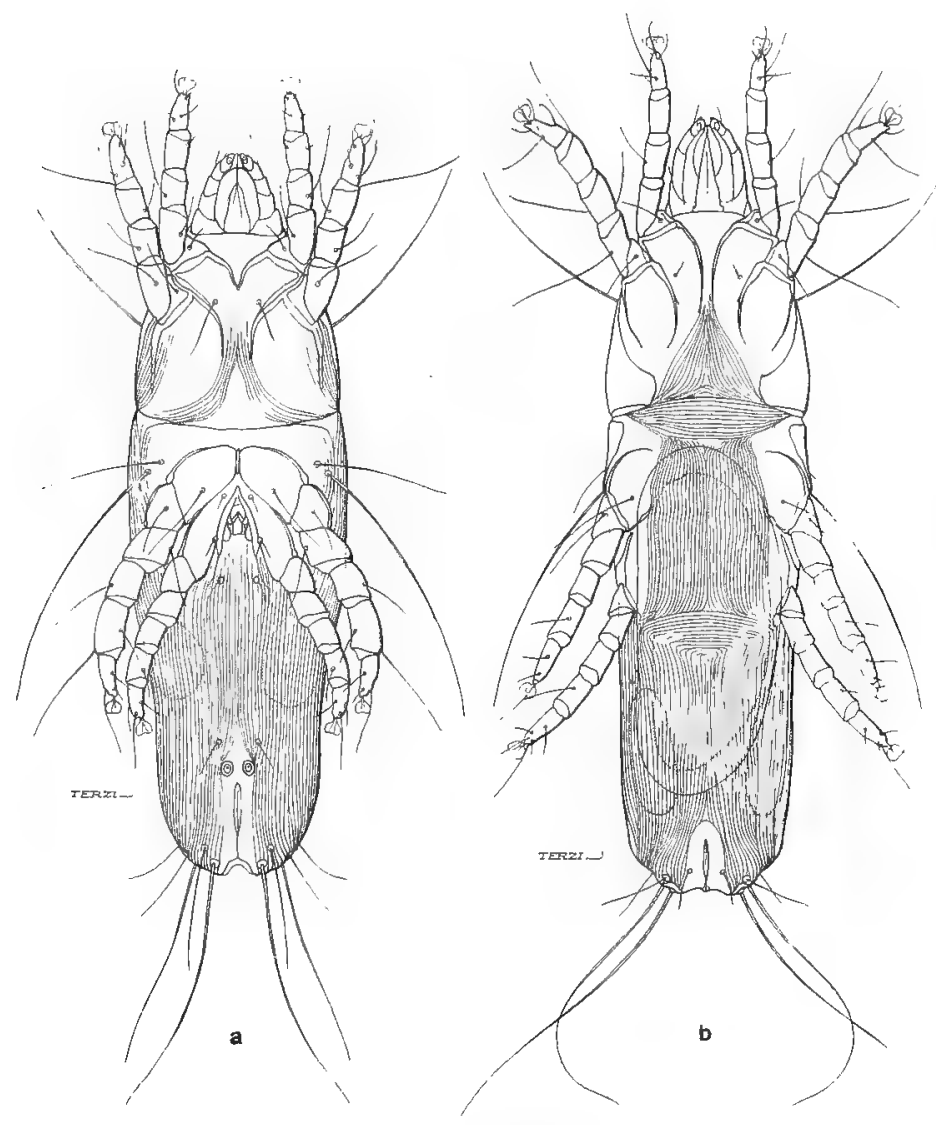

FiG. 31.

Dermoglyphus elongatus (p. 64).--(a) Hale, $\times 112$. (b) Female, $\times 120$. Ventral views. (Original.)

hairless. Elbows of front legs leathery and with the hair worn off, the upper part of the hind legs was also much affected. Irritation was evidently intense. Specimens of Notoedrus were easily obtained from all the diseased parts, and could be readily picked out of the flanks. No sperimens of Sarcoptes were to be met with in this 
case. It will be seen from the above that natural infection with Notoedrus is sometimes found in the dog, and may be intense and general in character instead of being confined to the head.

Notoedric Mange of Rabbits.-In the case of rabbits, Notoedrus usually attacks the face, especially round the eyes,

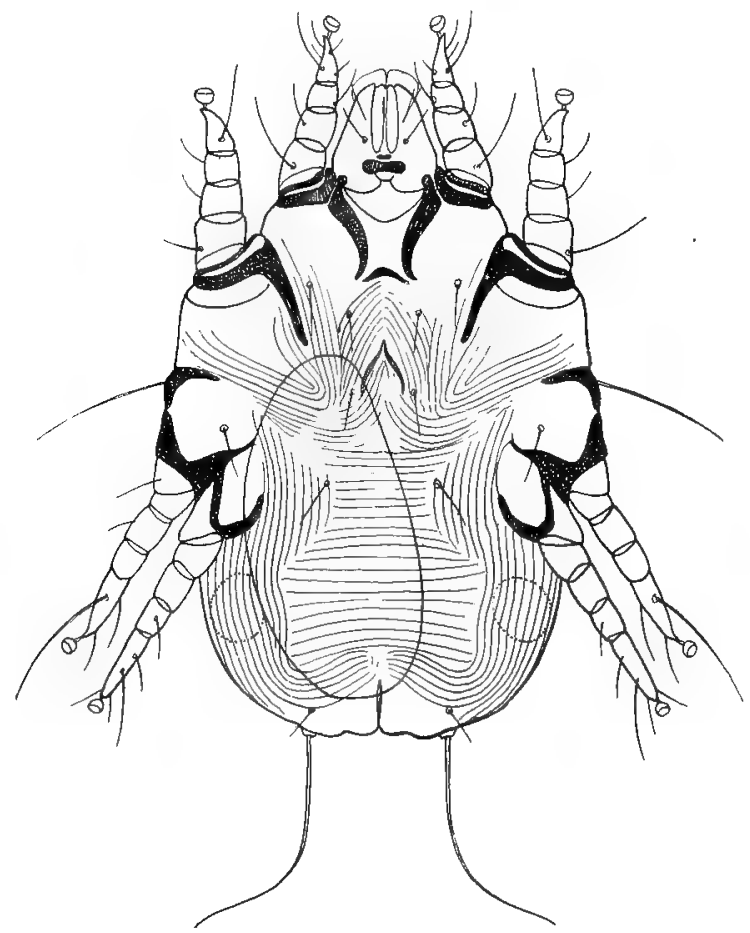

FIG. 32.

Epidermoptes bilobatus (p. 65), 9 , from below, $\times 268$. (After Neumann.)

more rarely attacking the ears. In advanced cases the legs and genital regions bccome affected. Scales and crusts are formed on the diseased parts of the animal.

It is probable that the Notoedrus of the rabbit $(N$. cati, var. cuniculi, Gerlach, 1857, figs. 10 and 11) is identical with that of the cat, or is at most merely a variety of the same species, but it is difficult to transmit the mite from the cat to this host. 
Notoedrus muris, Mégnin, 1880.

(Fig. 12.)

This mite especially affects the ears of its host, the common brown rat, giving rise to characteristic crusts and warty excrescences. Later the face, feet, tail, and genital region may become infected. When neglected, the disease sometimes terminates fatally. Both tame and wild rats suffer from this disease.

Genus Cnemidocoptes, Fürstenberg, 1870.

Without any distinct spines or scales on the dorsal surface,

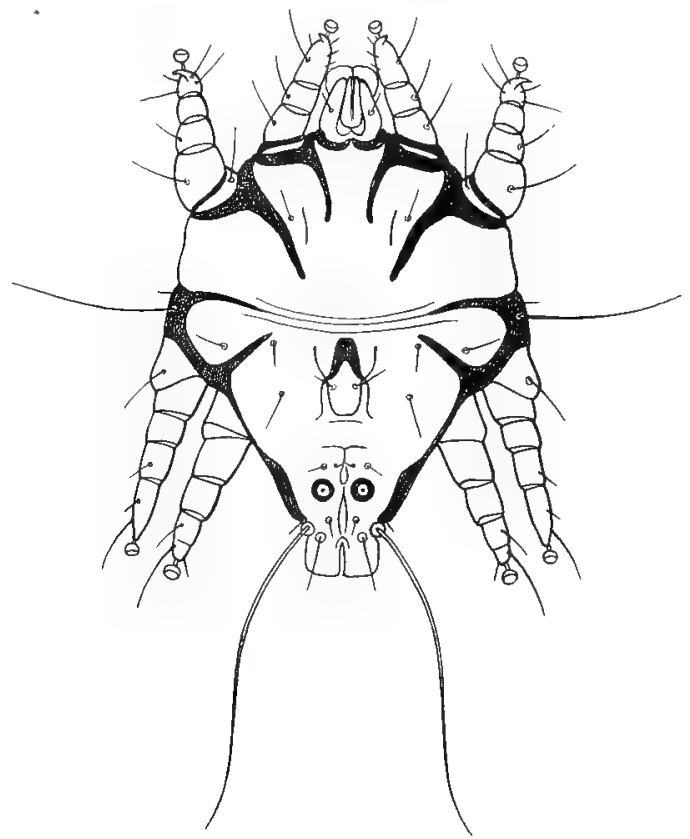

Frg. 33 .

Epidermoptes bilobatus (p. 65), ऊ, from below, $\times 300$. (After Neumann.)

only a few hairs being present. Both the third and fourth legs of the male end in a sucker, borne on an unsegmented peduncle (whereas only the fourth leg has a sucker in Sarcoptes and Notoedrus).

Cnemidocoptes mutans, Robin and Lanquetin, 1859.

(Figs. 13 and 14.)

This mite differs from the allied species, C. gallinae, by the arrangement of the linear markings on the dorsal surface, which 
are interrupted in the middle area so as to form raised almost scale-like sculpturings. A single pair of long hairs is present at the posterior end of the body.

Scaly-Leg in Fowls. - Scaly-leg in the domestic fowl is

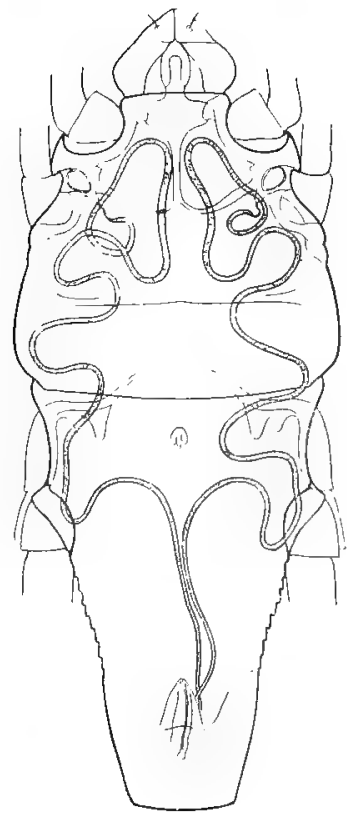

FIG. 34 .

Listrophorid mite (undescribed genus occurring on ('ricetomys gambianus), showing distribution of tracheal tubes (p. 69). (After Hirst, Journ. Quekott Microscopical Club, Nov. 1921.)

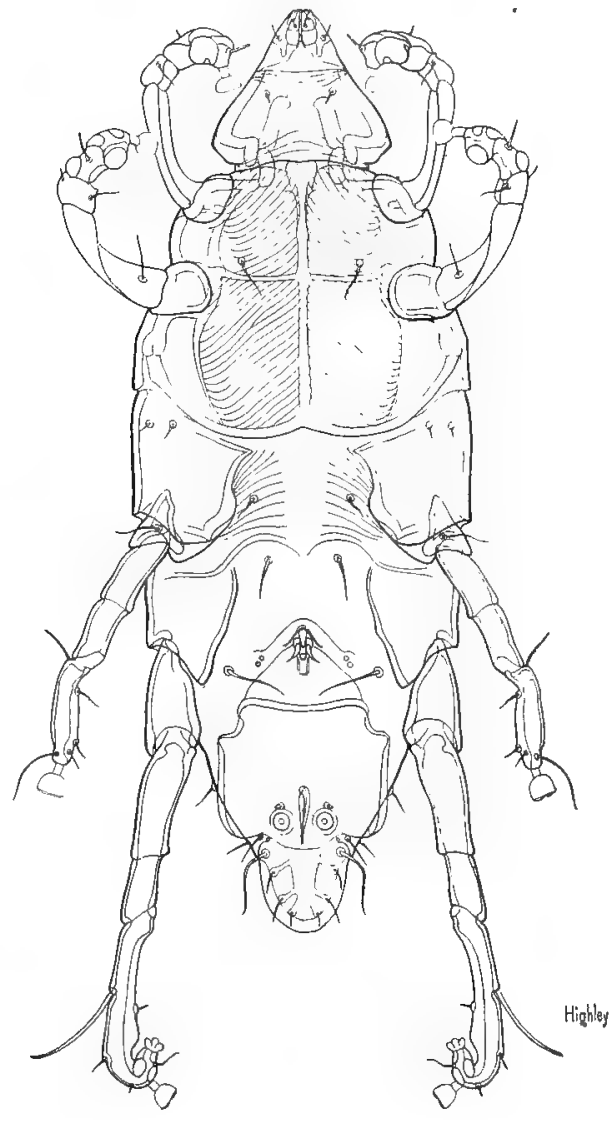

FIG. 35 .

Chirodiscoides caviae (p. 69), Listrophorid mite, parasitic on guinea-pig. Ventral viow of male, $\times 268$. (Original.)

caused by Cnemidocoptes mutans. The large scales of the tarsus of the feet are first affected, becoming raised at the edges by whitish floury powder, which is sometimes mixed with exuded serum. In advanced cases the disease assumes a characteristic form, the feet 
Mites Injurious to Domestic Animals.
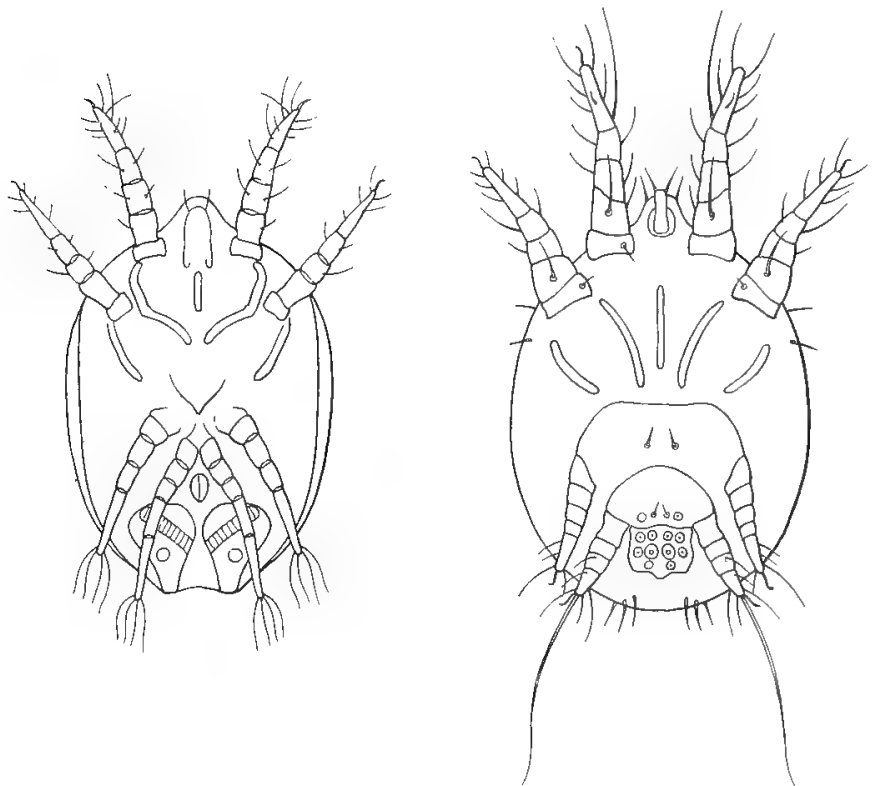

FIG. 36.

Hypopial or travelling nymphs of Tyroglyphidae (p. 70), ×c. 150. (After Michael.)
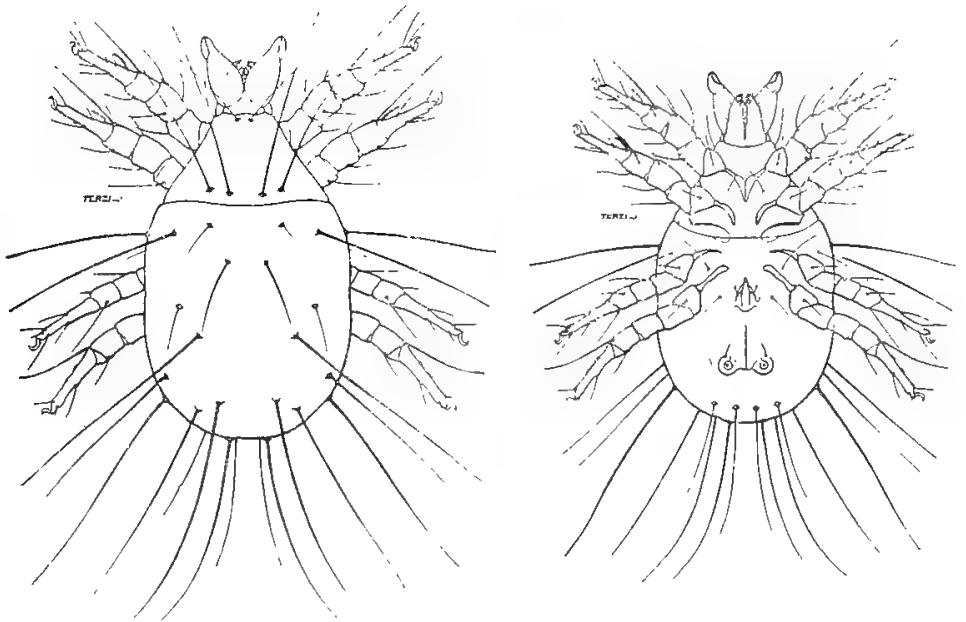

FIG. 37.

Tyroglyphus longior, var. castellanii (p. 71), dorsal and ventral aspects of male, $\times$ 97. (After Castellani and Hirst, Journ. Trop. Med. and Hyg.) 
becoming greatly distorted and covered with thick nodular spongy crusts. The comb and neck may also be attacked.

Crude petroleum should be applied to the feet, or they can be dipped into the oil. Another method is to soak the feet of the fowl in hot soapsuds, removing as much as possible of the infected scales, etc., and then rub them with ointment containing sulphur or 6 per cent. carbolic. Scaly-leg is highly contagious, and the fowls suffering from it should be isolated and their perches and runs disinfected.

Depluming Itch of Poultry.-Cnemidocoptes laevis, var. gallinae (fig. 15), is the mite present in depluming itch, a complaint chiefly characterised by the falling out of the feathers over more or

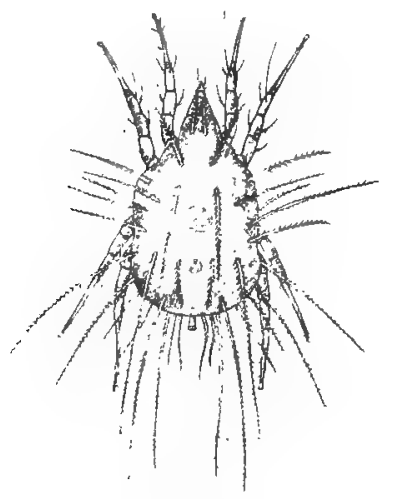

FIG. 38.

Glycyphagus domesticus (p. 71), × 50. (After Michael.)

less extended areas of the body. If a few feathers are plucked from. the back, top of wing, near the vent, breast, or thighs, the mite will be found embedded in the tissue or scales at the base of the quill. According to H. P. Wood, of the U.S. Bureau of Entomology :"The damage to the plumage is very evident. Infested fowls have a ragged appearance, with a good many broken feathers or perhaps bare spots. This appearance is more evident in the summer and fall than it is soon after moulting. It is quite evident that any damage done to plumage would be detrimental to show birds. We believe also that more injury is done to poultry generally by this mite than is commonly supposed. There seems to be some itching, which may result in feather pulling, causing some hens to become quite 
bare...." Depluming itch occurs both in North America and Europe. Neumann says it is especially prevalent in the spring and during summer, disappearing more or less completely in autumn, and usually making its reappearance in March or April. The typical form of this species (Cnemidocoptes laevis) was described by Railliet in 1885 from specimens found on a carrier pigeon. Mégnin observed

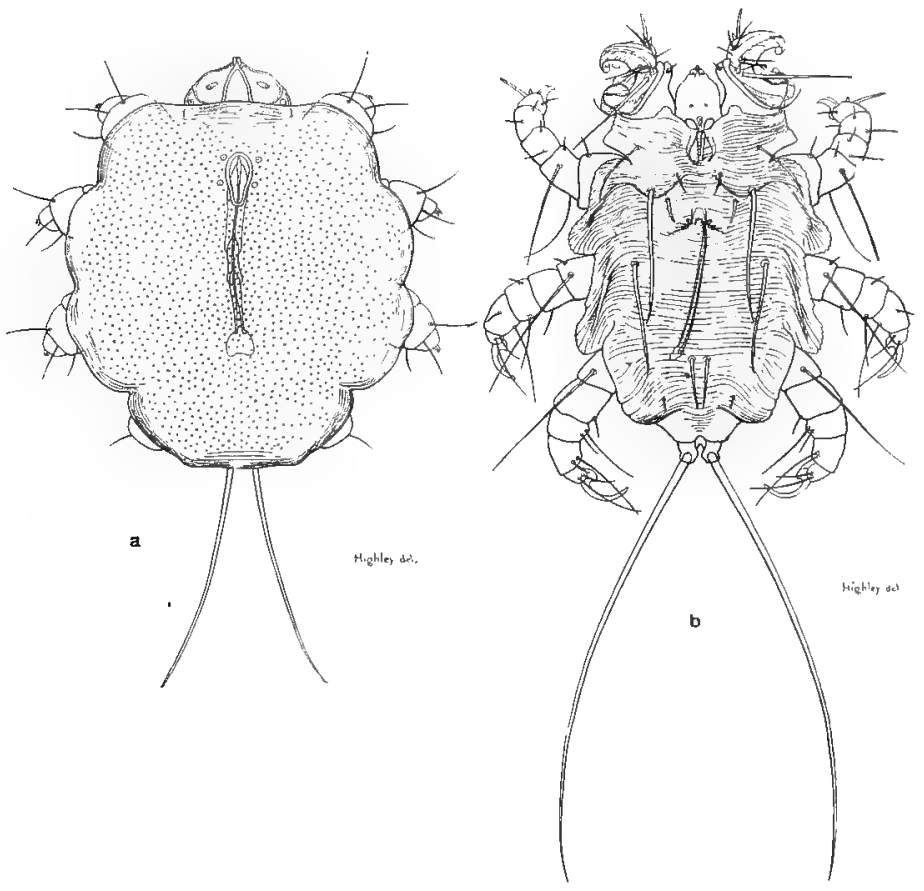

FIG. 39.

Cheyletid Mites. (a) Psorergates musculi (p. 73), parasitic in skin of house mouse, dorsal view of male, $\times 315$. (b) Myobia sp. (p. 73), a pilicolous mite, dorsal view of male, $\times 105$; (After Hirst, Studies on Acari, no. 1.)

a mite causing similar trouble in pheasants, which is, perhaps, a variety (var. phasiani). Another species (C. prolificus, Railliet and Henry) occurs on geese in France.

Bishopp and Wood recommend dipping in the following solution as a cure for depluming itch, for it kills any lice that may be present on the bird in addition to the mites:- Sodium fluoride (chemically pure) $\frac{3}{4}$ oz.; flowers of sulphur, 2oz.; laundry soap 
about $\frac{1}{2} \mathrm{oz}$.; water, 1 gallon.* Dipping of poultry is best done during the summer months, on a warm summer day, so that the fowls will dry quickly. Windy weather should be avoided. The operation should be completed a considerable time before sundown, so as to enable the fowls to become thoroughly dry before going to roost. The dipping should be done in a large tub filled to within six or eight inches of the top. In dipping the fowls it is best to hold the

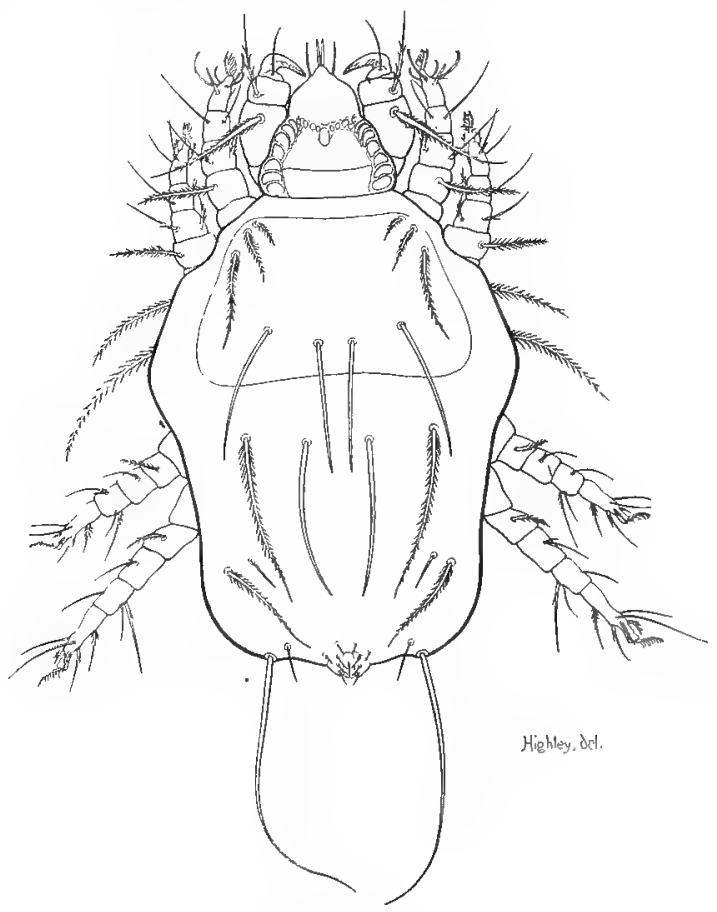

FIG. 40.

Cheyletiella parasitivorax (p. 73).-A pseudoparasite of rabbit and domestic cat, $x$ 153. (After Hirst, Ann. Mag. Nat. Hist. xx. 1917.)

wings over the back with the left hand and quickly submerge the bird in the solution, leaving the head out, while the feathers are thoroughly ruffled with the other hand so as to allow the solution to penetrate to the skin on the different parts of the body. The head is ducked once or twice and the bird is allowed to drain and is then released. It is not necessary to keep the fowl under the

* See "Mites and Lice on Poultry," by F. C. Bishopp and H. P. Wood, Farmers' Bulletiu no. 801, revised edition, 1919, U.S. Dept. of Agriculture. 


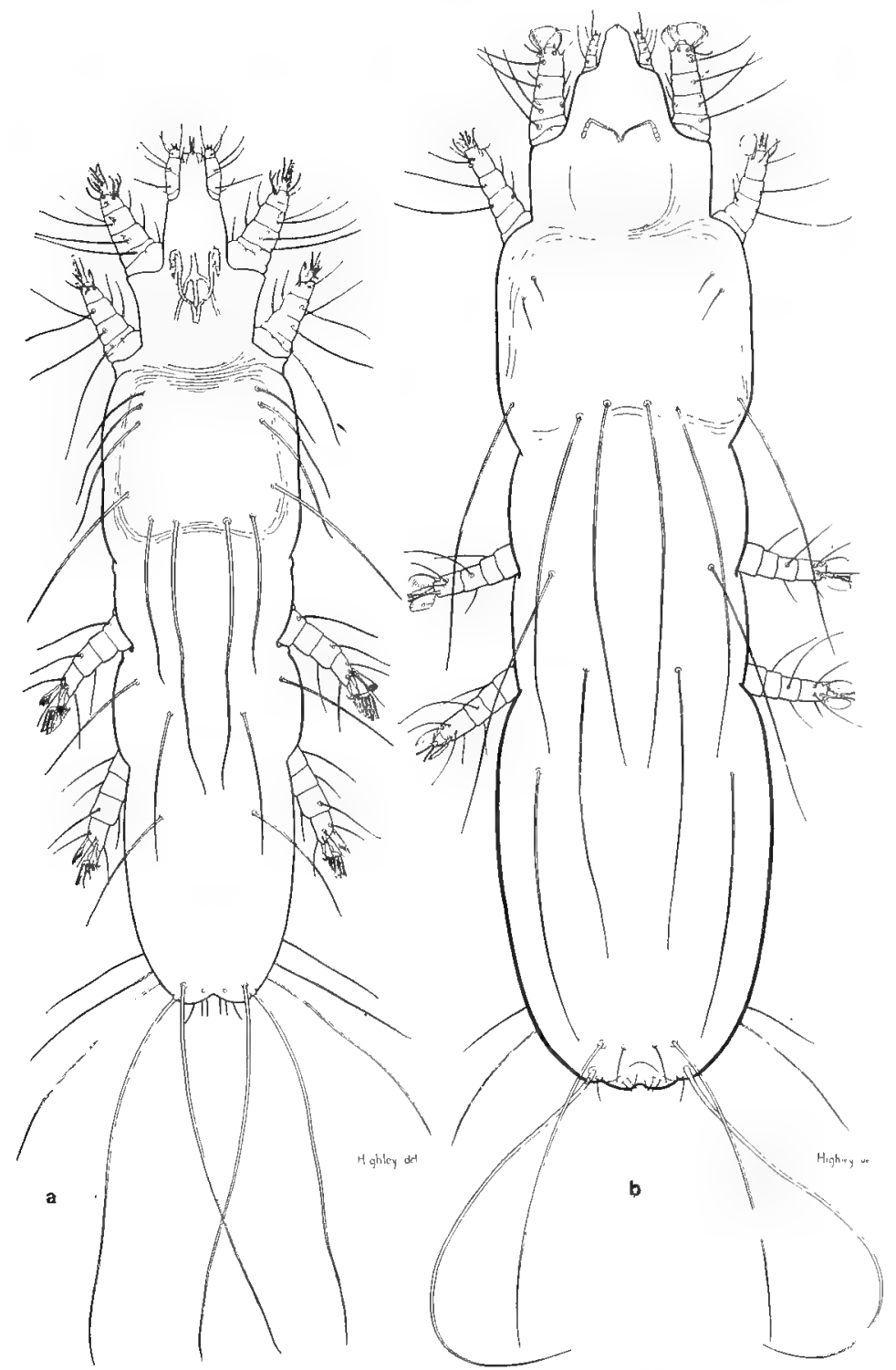

FIG. 41.

(a) Syringophitus bipectinatus (p. 74).-A Cheyletid mite living in the quills of the feathers of the domestic fowl, $\times 97$. columbae (p. 75), | from quill of domestic pigeon. Dorsal aspect of females. (Original.) 

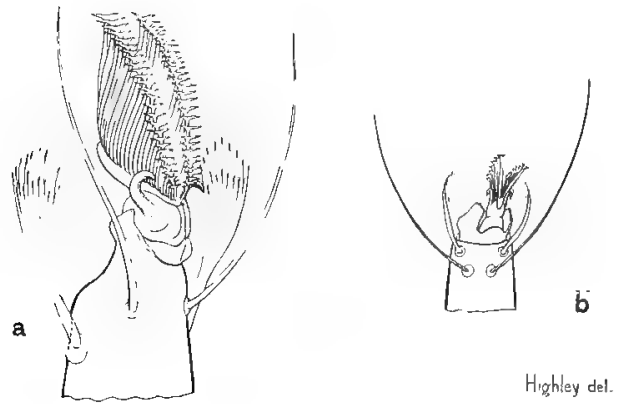

Fig. 42.

(a) Tarsus of leg of Syringophilus bipectinatus (p. 74). (b) Tarsus of Syringophilus columbae (p. 75). (Original.)

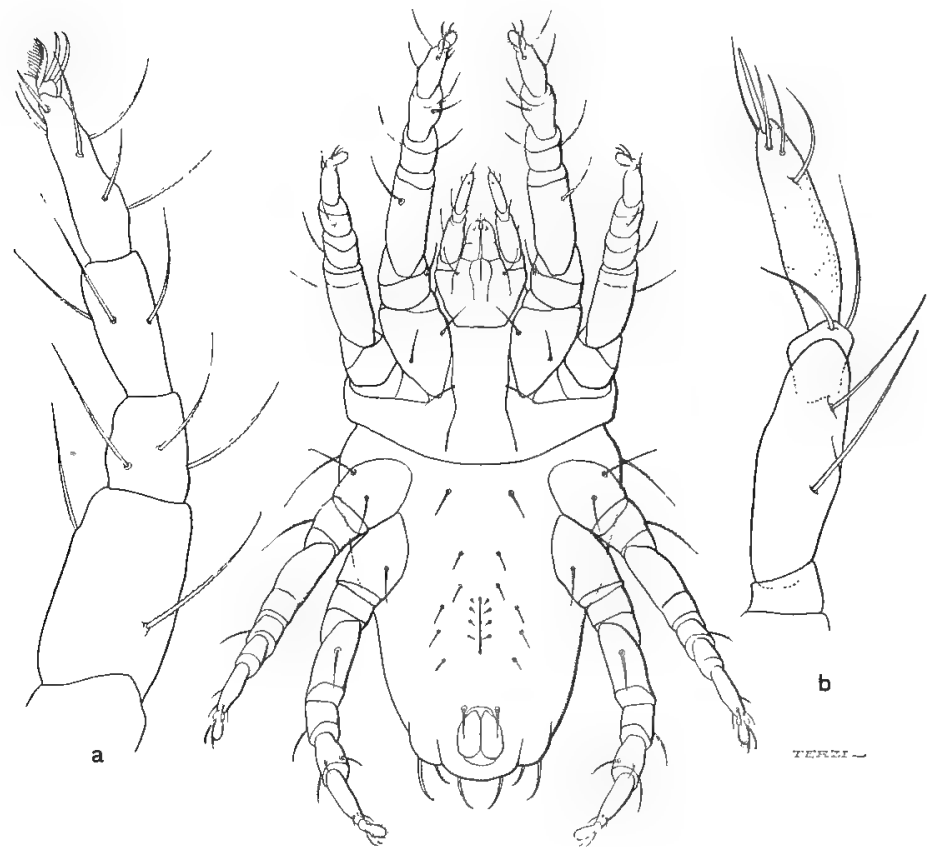

FIG. 43.

Tydeus molestus (p. 76), o, from below, $\times 250$. (a) Leg. (b) Palp, much enlarged. (Original.)

fluid for more than thirty seconds and the head only an instant. Care should be taken to keep the dip well stirred so as to keep the 
sulphur in suspension. Sodium fluoride solution should not be allowed to remain in galvanized vessels or tubs for any length of time or it will damage them.

Two species of Sarcoptid mites (Cytoleichus (=Cytodites) nudus, Vizioli, and Laminosioptes cysticola, Vizioli) are internal parasites of the fowl, and both are frequently found in this country. Cytoleichus nudus (fig. 16) is a minute soft-skinned, smooth, oval mite, the hairs on its body being few in number and very short.

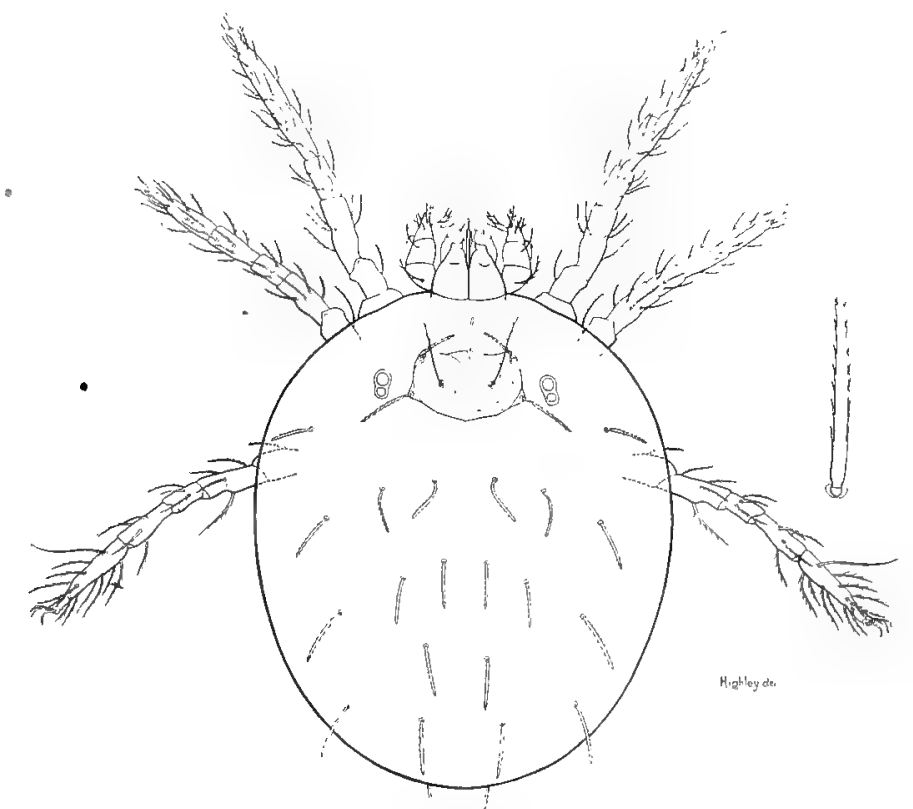

FIG. 44.

Leptus (Trombicula?) similis, Hirst (p. 78).-A larval Trombidid mite occurring on the domestic fowl in North America, $\times 130$. (Original.)

Numbers of this mite often occur in the air sacs and respiratory tract of the fowl, pheasant, etc. It is possible that when present in very large numbers they may affect the health of their host.

Another species of Cytoleichus (C. banksi) is a parasite of squirrels in California, whilst two specimens of a species of this genus were found by Castellani embedded in the fat of the omentum of a dead negro in Uganda.

Laminosioptes cysticola (fig. 17) is a much more elongated species. Its presence may be detected by the occurrence of calcareous 
nodules or cysts of varying size in the subcutaneous tissues. The living mites can be found in the tissues and not in the cysts, which apparently are formed round dead specimens.

Mercier and Lebailly discovered numerous specimens of these

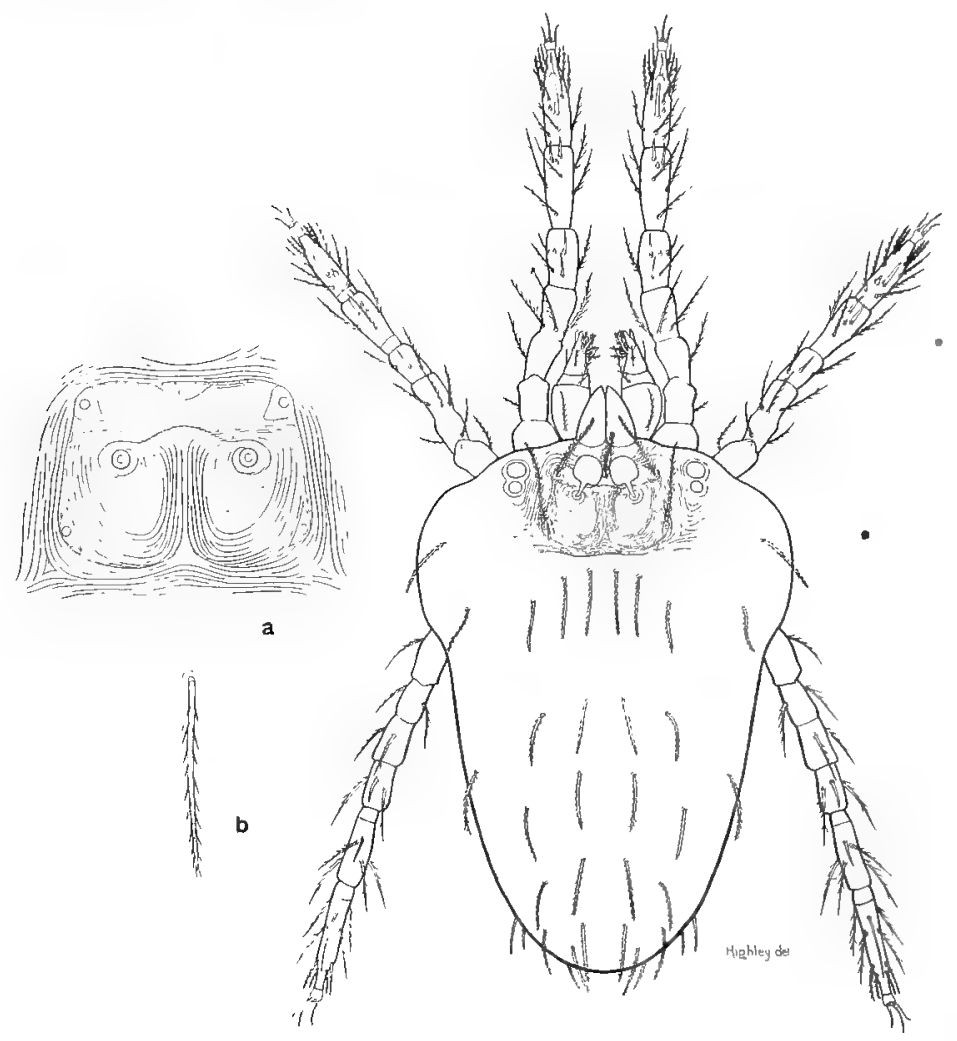

Fis. 4.5 .

Schünastia americane, Hirst (p. 78).--A larval Trombidiid mite" occurring on the domestic fowl in North America, $\times 236$. (a) Scutum of same greatly enlarged. (b) 1 hair greatly enlarged.

(Original, )

two species of mites in a hen which had a cancerous tumour (myxosarcoma) adhering to the wall of the air-sac near the kidney, and suggest that Cytoleichus nudus may, perhaps, inoculate the virus of the disease in much the same way as has already been done experimentally by means of the needle of a hypodermic syringe. 


\section{Family A NALGESIDAF، (Fintler, d/ites).}

The mites of this family are closely allied both to the Sarcoptidae and Tyroglyphidae, being somewhat intermediate between these
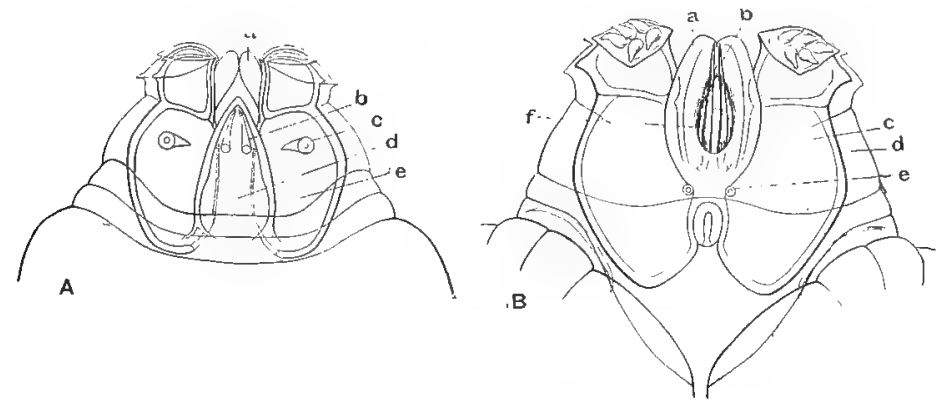

FIG. 46. (See pp. 79-86.)

A. Capitulum of Demodex folliculorum, from above. (a) Labial sheath of chelicera. (b) Chelicera (upper finger). (c) Spinule on palp. (d) Epistome. (e) Palp. B. Capitulum of Demodex folliculorum, from below. (a) Labial sheath of chelicera. (b) Chelicera (lower finger). (c) Palp. (d) Membranous capitulum. (e) Supposed opening of respiratory system. (f) Mouth. (After Hirst, Studies on Acari, no. 1.)

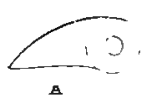

A
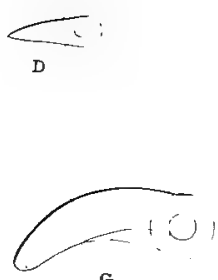

G

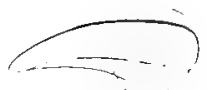

B
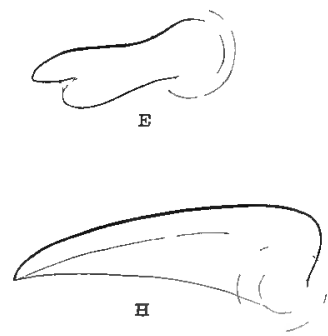

FIG. 47. (See pp. 79-86.)
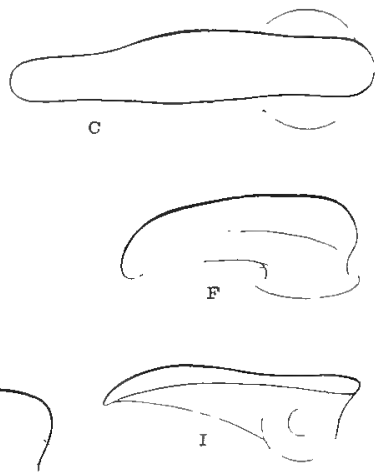
Dorsal spinule on capitulum (palp) of Demodex spp. A. of
$D$. folliculorum B. of $D$. canis. C. of $D$. equi. D. of $D$. cati. E. and F. Spinule of $D$. bovis, showing variation in form. G. of D. muscardini. H. of $D$. ratti. I. of D. arvicolae, var. musculi. (After Hirst, Studies on Acari, no. 1.)

two groups. In some forms there is a lateral vesicle on each side of the abdomen, as in the Tyroglyphidae. They are found chiefly 

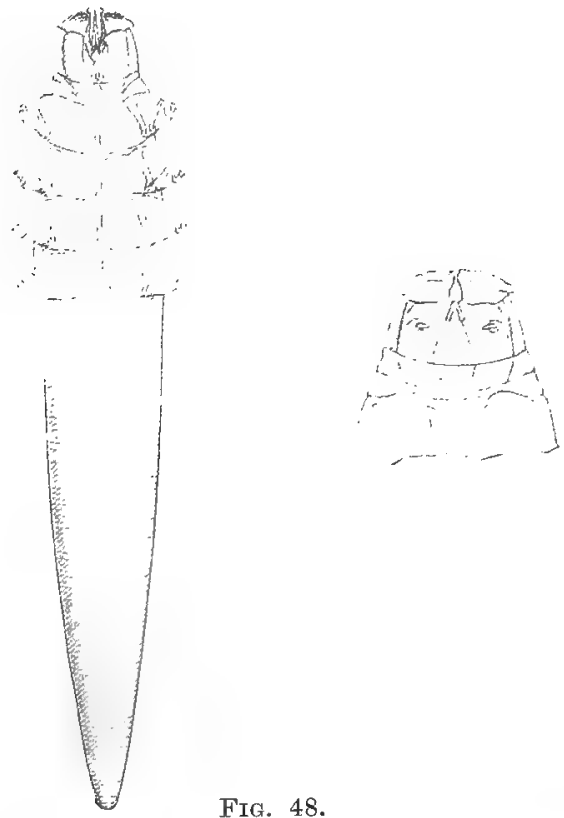

FIG. 48.

Demodex canis (p. 79). - Ventral view of female, $\times 328$, and capitulum from above. (After Hirst, Studies on Acari, no. 1.)
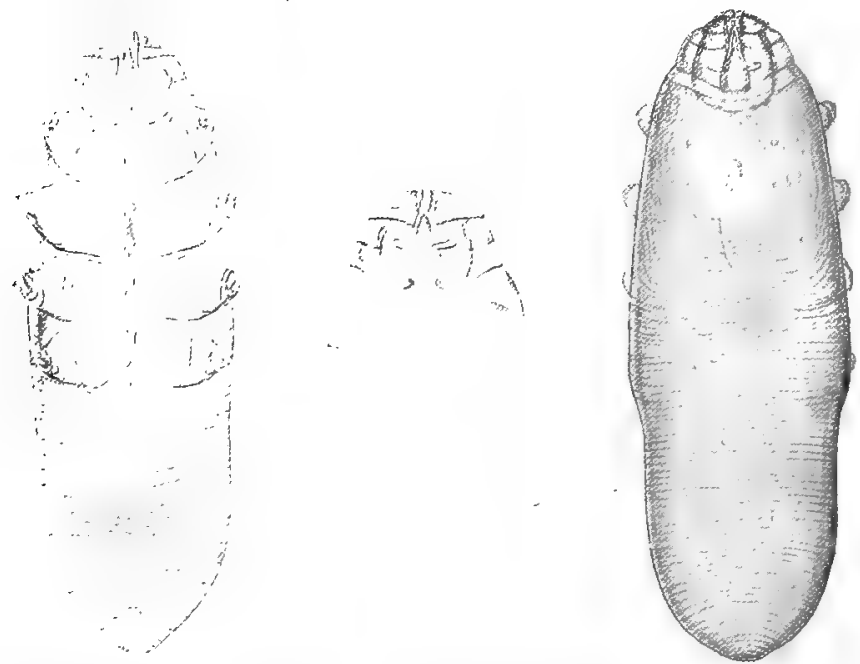

FIG. 49.

Demodex equi (p. 80). - Female from below, $\times 297$, and male from above, $\times 330$. Also dorsal view of capitulum. (After Hirst, Studies on Acari, no. 1.) 
between the barbules of the feathers of birds or more rarely make their way into the interior of the quills. The special nymph (Hypodectes, fig. 18) of certain forms (genus Falculifer) penetrates into the subcutaneous tissue of the pigeon, flamingo, and other birds. These

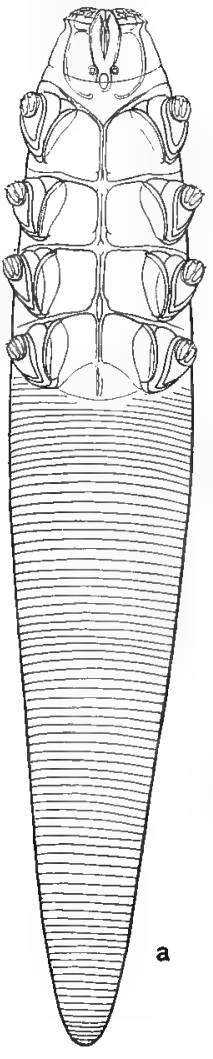

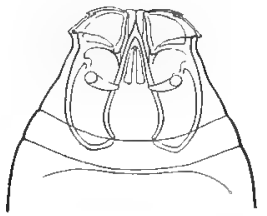

b

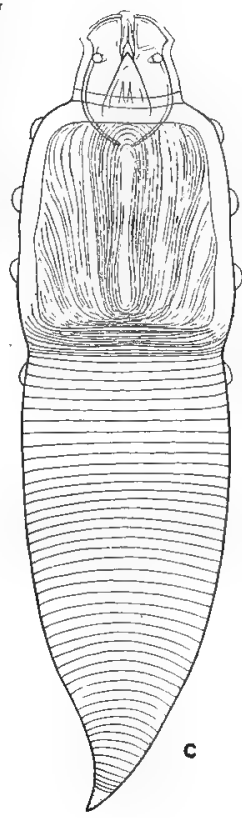

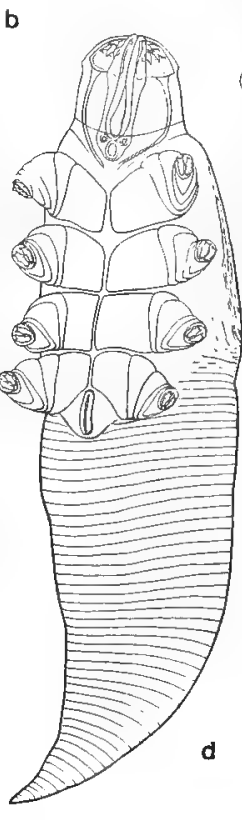

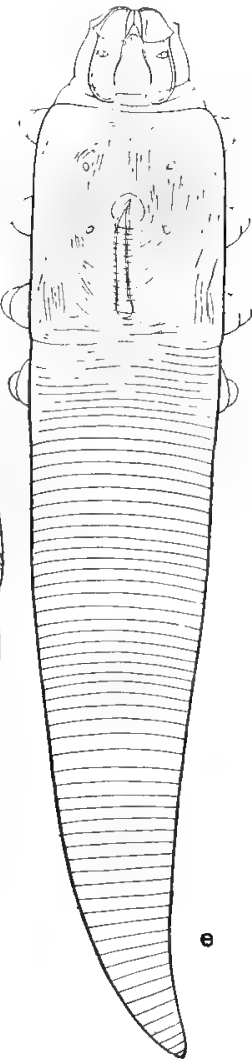

FIG. 50.

(a) Demodex canis. var. ovis (p. 84), $q$, from below, $\times 456$. (b) Capitulum of same, from above. (c) and (d) Demodex phylloides (p.82), of (from pig), dorsal and ventral aspects, $\times 378$. (e) Demodex cati (p. 86), of, from above, $\times 566$ (After Hirst, Studies on

Acari, no. 1.)

nymphs have also been found in large numbers in the thymus of pigeons both in Europe and North America.

The anterior legs in the genus Megninia are characteristic, being armed with large spines (see fig. 19). One of the species of this genus ( $M$. cubitalis, Mégnin), which has the posterior lobes of the 
male divided into two segments by a transverse line (see fig. 22 b) is found on the feathers of the turkey, peacock (var. ginglymura), and fowl, whilst another (M. columbae, Buchholz, figs. 20 and 21) occurs on the domestic pigeon, fowl, canary, and certain other birds; a third ( $M$. velata, Mégnin, fig. 22 a) is found on ducks.

Pterolichus obtusus, Robin (figs. 23 and 24) is a feather mite occurring on several kinds of birds, especially on the red-legged or French partridge (Perdrix rubra), and is sometimes found on fowls.
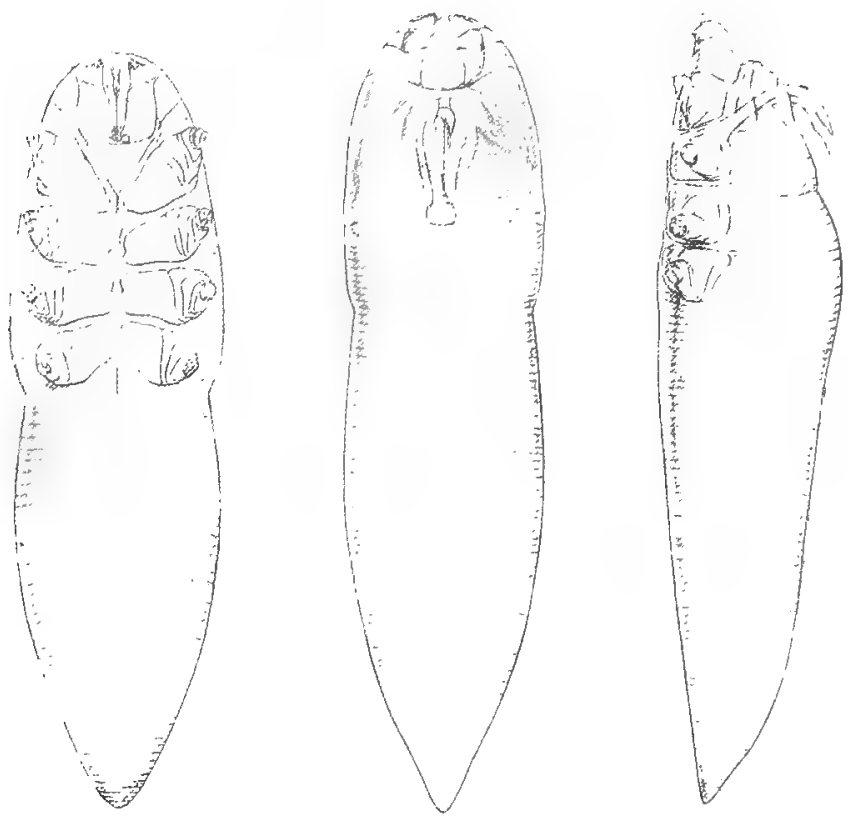

FIG. 51 .

Demodex bovis (p. 83).-Ventral view of female, $\times 335$, and dorsal and lateral views of male, $\times 324$.

The specimens of this mite figured in this pamphlet were taken on chickens in the United States. Another member of the genus (Pterolichus bicaudatus, Gervais, figs. 25 a and 26 a) occurs on ostriches in South Africa and also in California, whilst an allied species ( $P$. sculpturatus, Hirst, figs. $25 \mathrm{~b}$ and $26 \mathrm{~b}$ ) lives on and inside the feathers of the South African ostrich in the Transvaal. Another feather mite (Freyana chanayi, Trouessart) is met with on turkeys (fig. 30). Two species of Dermoglyphus (D. minor, Nörner, and D. elongatus, Mégnin) live inside the quills of the feathers of fowls, the latter 
species (fig. 31) is elongated in form like the species of Syringophilus, which also live inside the quills of various birds (see p. 74, fig. 41).

Several species of feather mites are found on pigeons, viz, Megninia columbae, Buchholz, mentioned above, Falculifer rostratus,

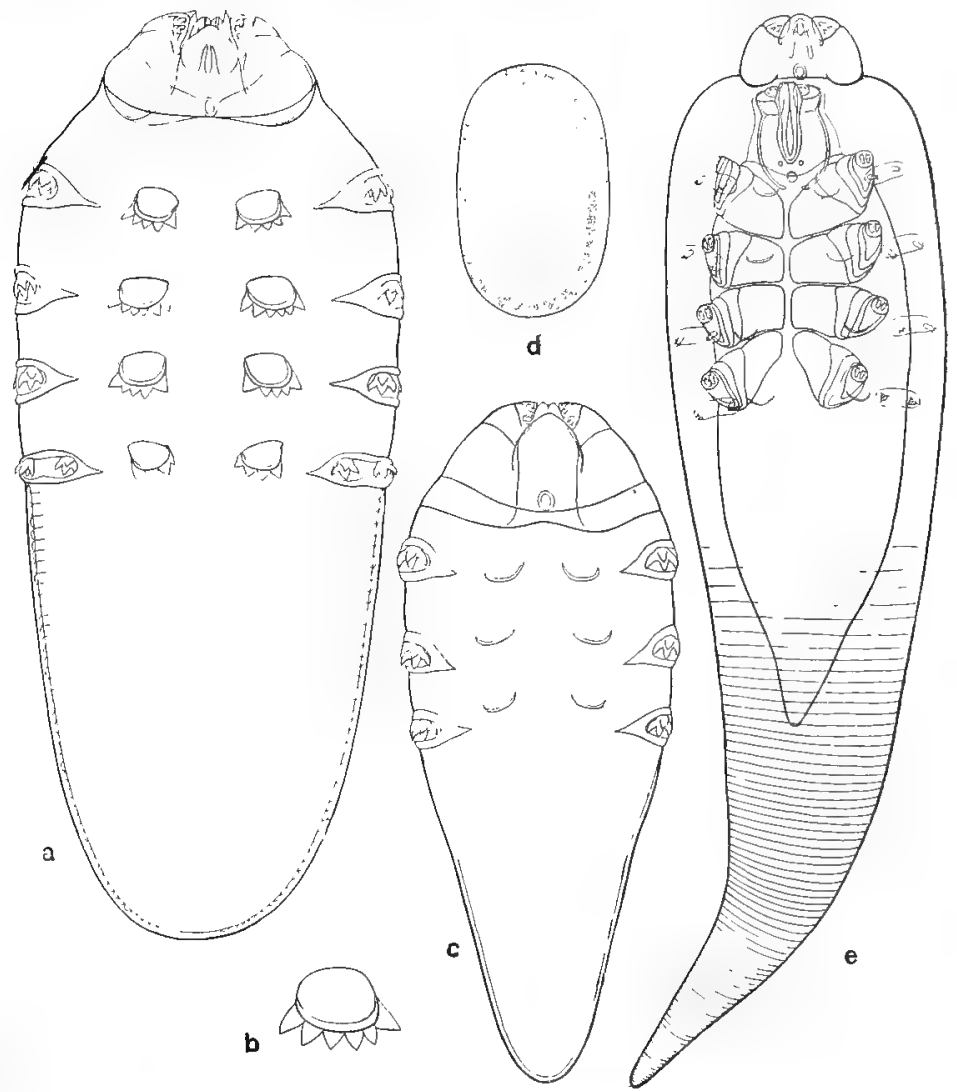

Fig. 52.

Stages in life cycle of Demodex. (a) Young nymph of Demodex muscardinus. (b) One of the epidermal scales of this nymph very greatly enlarged. (c) Larva of D. muscardinus. (d) Egg of $\bar{D}$. muscardinus. (e) Large nymphal stage of $D$. bovis, showing completely formed adult inside, $\times 328$.

Buchholz, Falculifer cornutus, Trouessart (in America), Analyes bifidus, Nitzsch, and Pterophagus strictus, Mégnin.

Two very minute mites allied to the feather mites (Epidermoptes bilobatus, Rivolta (figs. 32 and 33), and Rivoltasia bifurcata, 

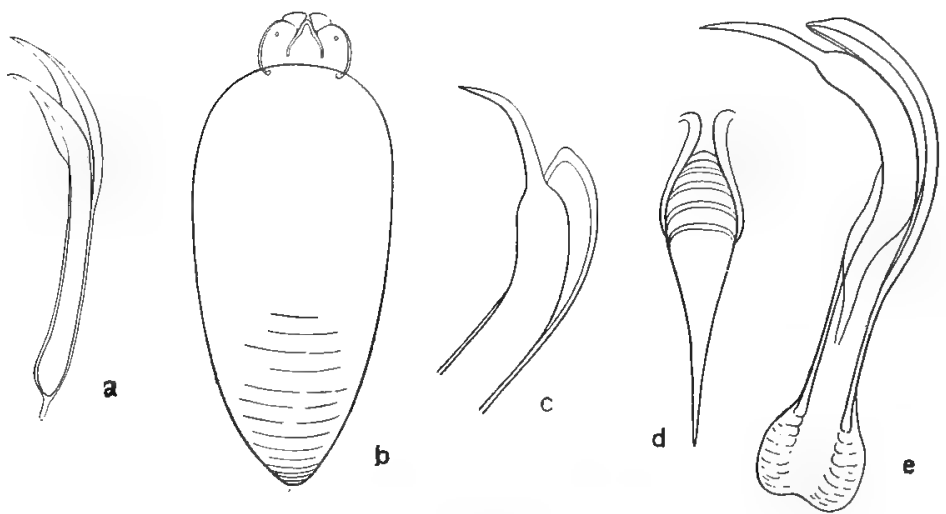

FIG. 53.

(a) Penis of Demodex cati. (b) Early larva of D. bovis. (c) Tip of penis of $D$. bovis, very greatly enlarged. (d) End of same as it appears when protruding from sexual orifice. (e) Penis of $D$. bovis, showing its entire length. (After Hirst, Studies on Acari, no. I.)

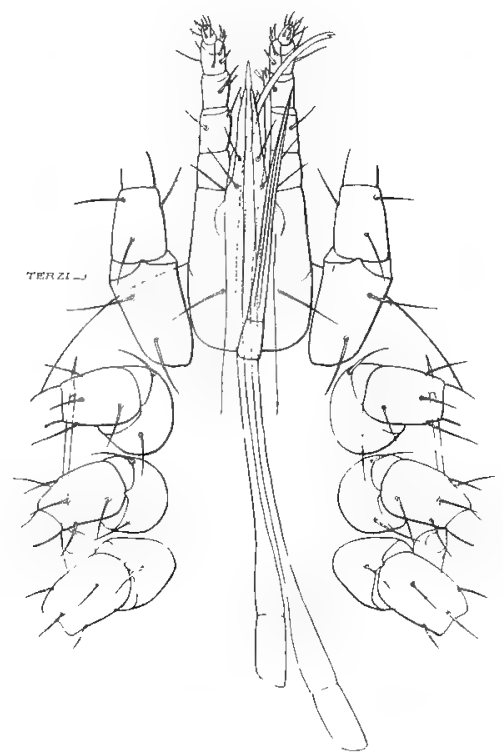

FIG. 54.

Anterior end of Imrmimyssus (p. 87), showing cheliceraje in situ. (After Hirst, Journ. Zool. Res., 1916.) 
Rivolta), which have the skin only weakly chitinized, live on the surface of the skin of the domestic fowl. In some cases of squamous

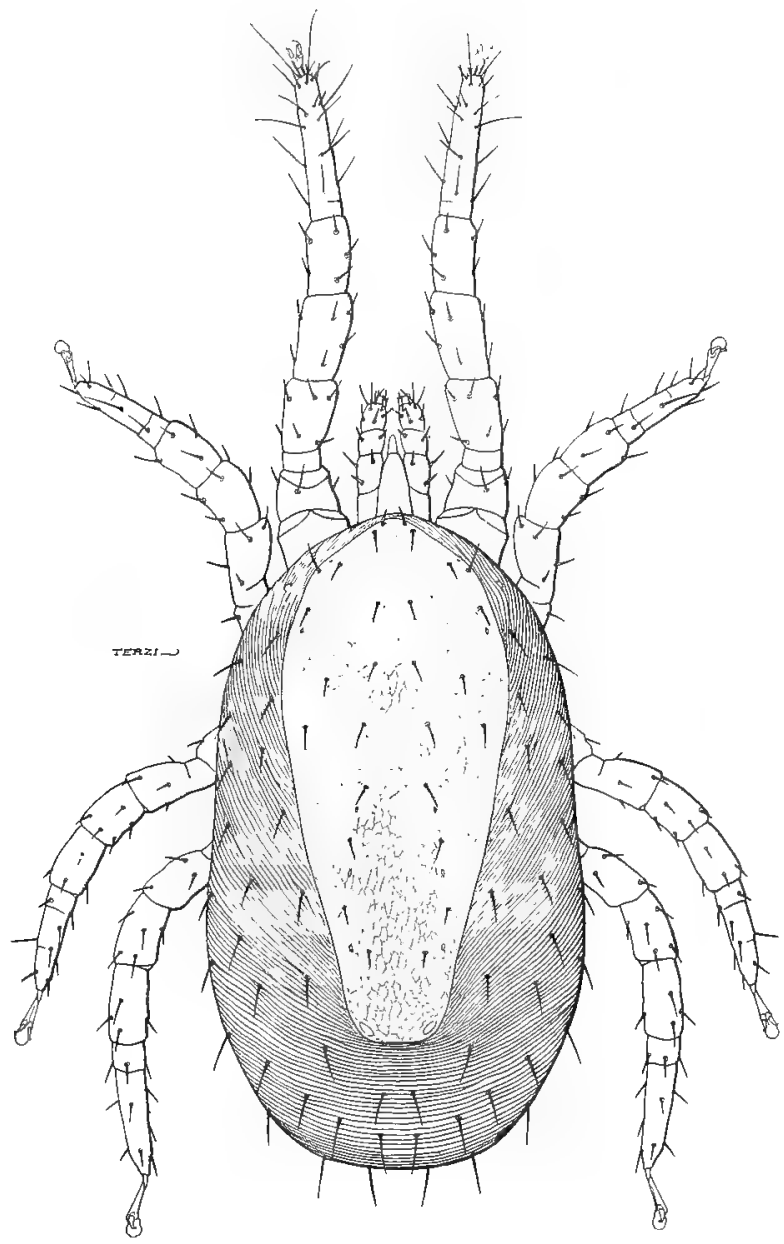

FIG. 55. Dermanyssus gallinae (p. 87).-Dorsal view of female, $\times 104$.

skin diseases (Pityriasis) they have been found in great numbers and have been accused of causing the trouble. 


\section{FAMII Y IISTIROPHORIDAE.}

The mites of the family Listrophoridae live in the fur of various mammals (bats, shrew mice, weasels, rodents, etc.). The

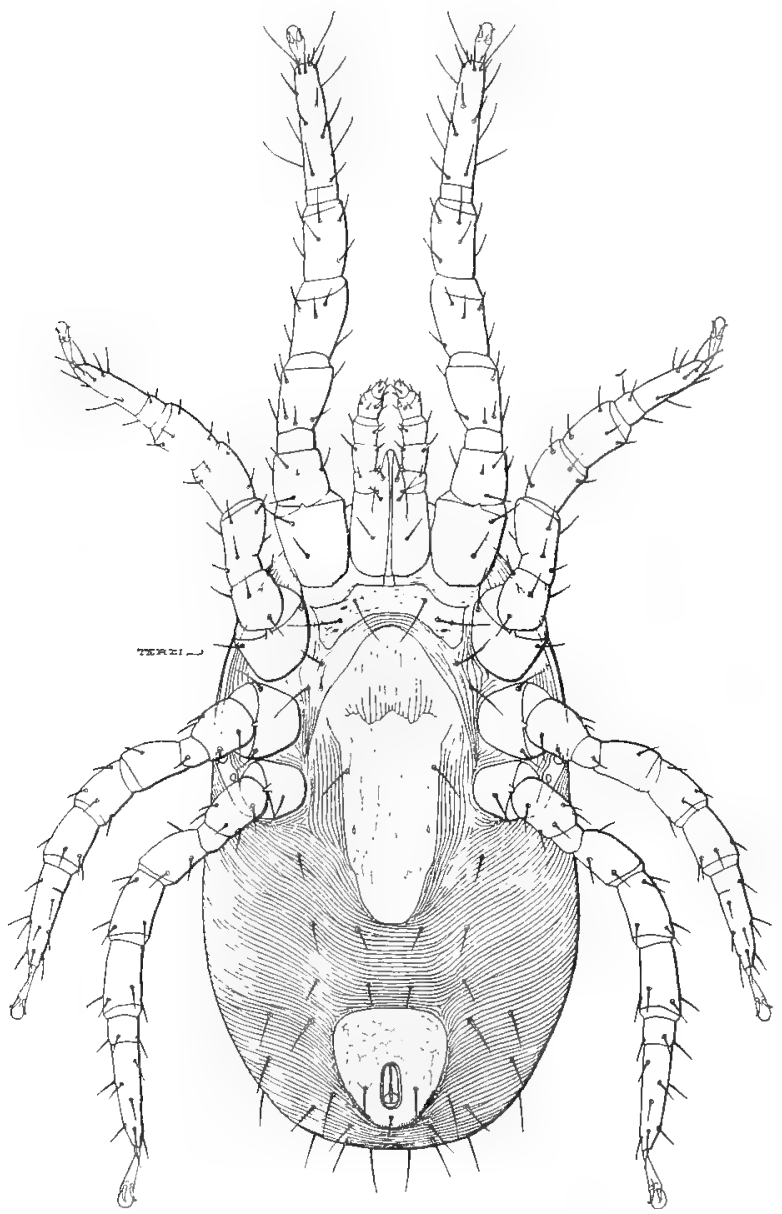

Fic. 56.

Drrmanyssus gallinae (p. 87).--Tentral view of female, $\times 104$.

(Original.)

lips or some of the legs are modified so as to form organs for clasping the hairs of the host. Many species are compressed 
laterally like the insects of the family Pulicidae (fleas), in order to enable them to progress rapidly through the fur of the host. Distinct tracheal tubes are present in some Listrophorid mites (fig. 34). (See Hirst, Journ. Quekett Club, November, 1921.)

Listrophorus gibbus, Pag., is often very abundant in the fur of

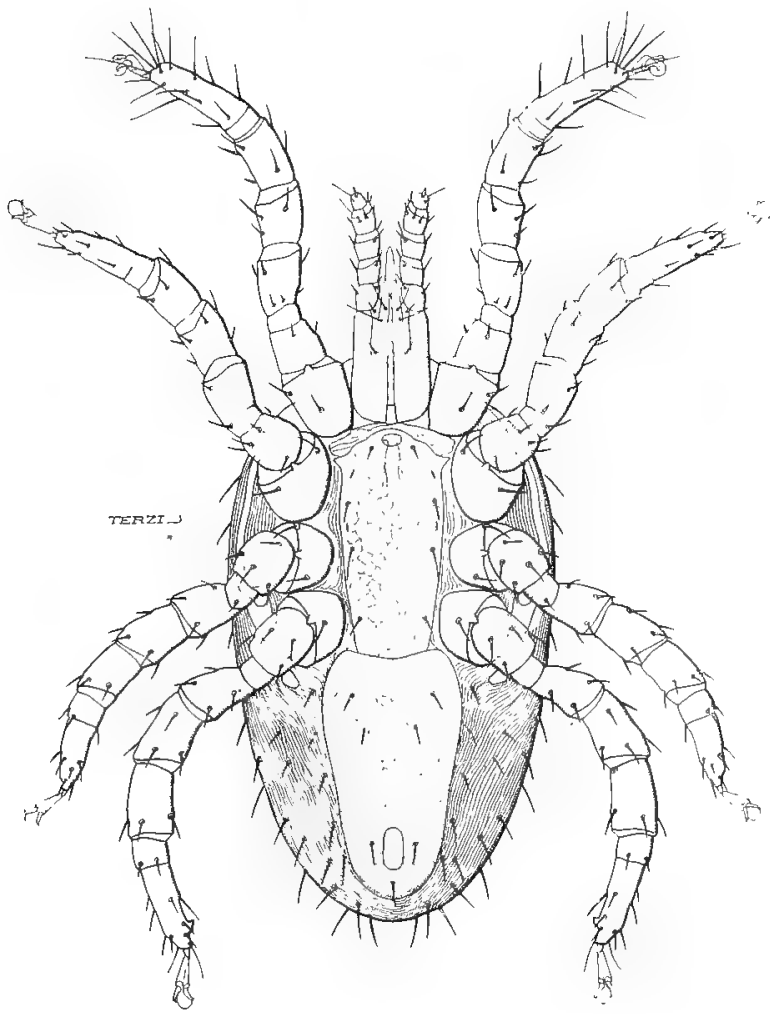

FIG. 57.

Dermanyssus gallinae (p. 87).- Ventral view of male, $\times 123$.

(Original.)

rabbits. Another species (L. mustelae) is found on ferrets. A minute Listrophorid mite (Chirodiscoides caviae, Hirst, fig. 35) attaches itself to the hairs on the back of guinea-pigs.

It is said that some of the species of Listrophorus are preyed upon byispecies of Cheyletinae, which use the rabbit's fur as a hunting forest. 


\section{FAMIIY TYROGISPHIDAE.}

Minute, pale-coloured mites, without any definite respiratory system, their body is usually rather soft, being weakly chitinized. They are mostly free-living, feeding on animal or vegetable matter, especially if in a state of decay. A few species are associated with mammals, living in their nests, and the travelling nymphs or hypopi

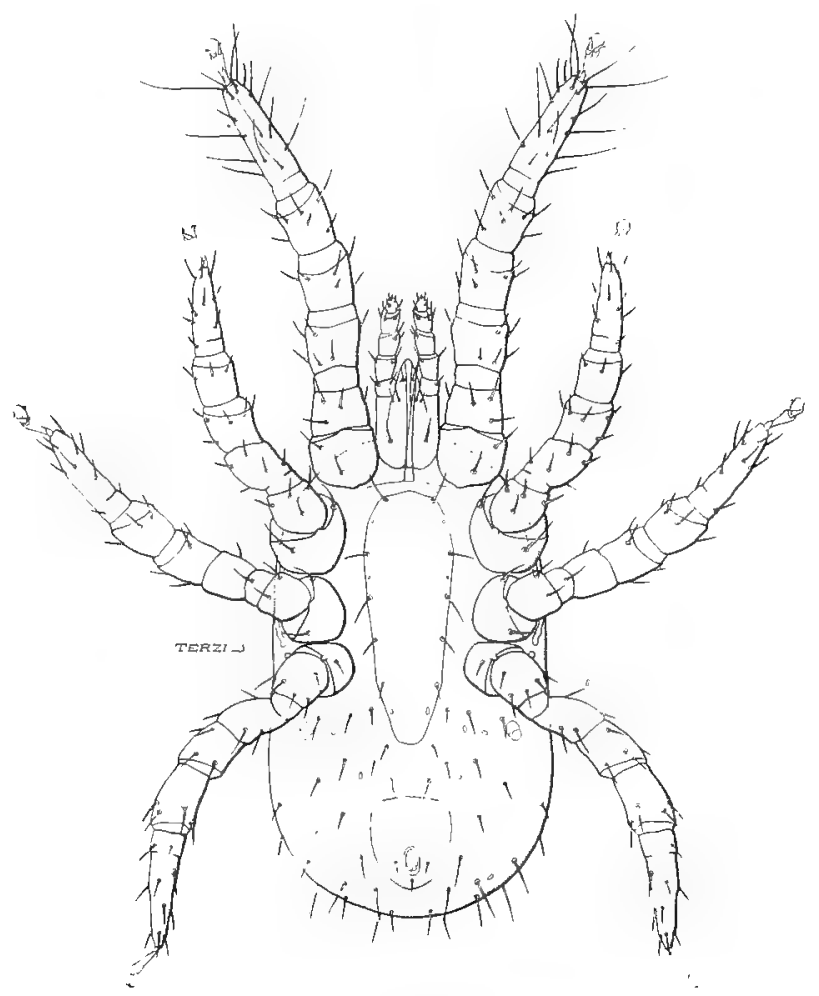

Fig. 58.

Second nymphal stage (deutonymph) of Drrmanyssus gallinae (p 87), from below. (Original.)

of these forms usually have a special apparatus on the ventral surface of the body for grasping the hairs of the host (fig. 36). The travelling nymphs of other species bear discs provided with suckers in the same position, enabling them to attach themselves to insects (fig. 36).

Several species of Tyroglyphids occur accidentally on the skin of 


\section{Mites Injurious to Domestic Animals.}

horses - for instance, Aleurobius farinae, Tyroglyphus longioi (fig. 37),

Glycyphagus domesticus, G. cadaverum, and G. ornatus. Hypopial nymphs of several tyroglyphid mites have also been found on horses.

Aleurobius farinae, De Geer, 1778.

This species is a well-known pest of grain and is sometimes also

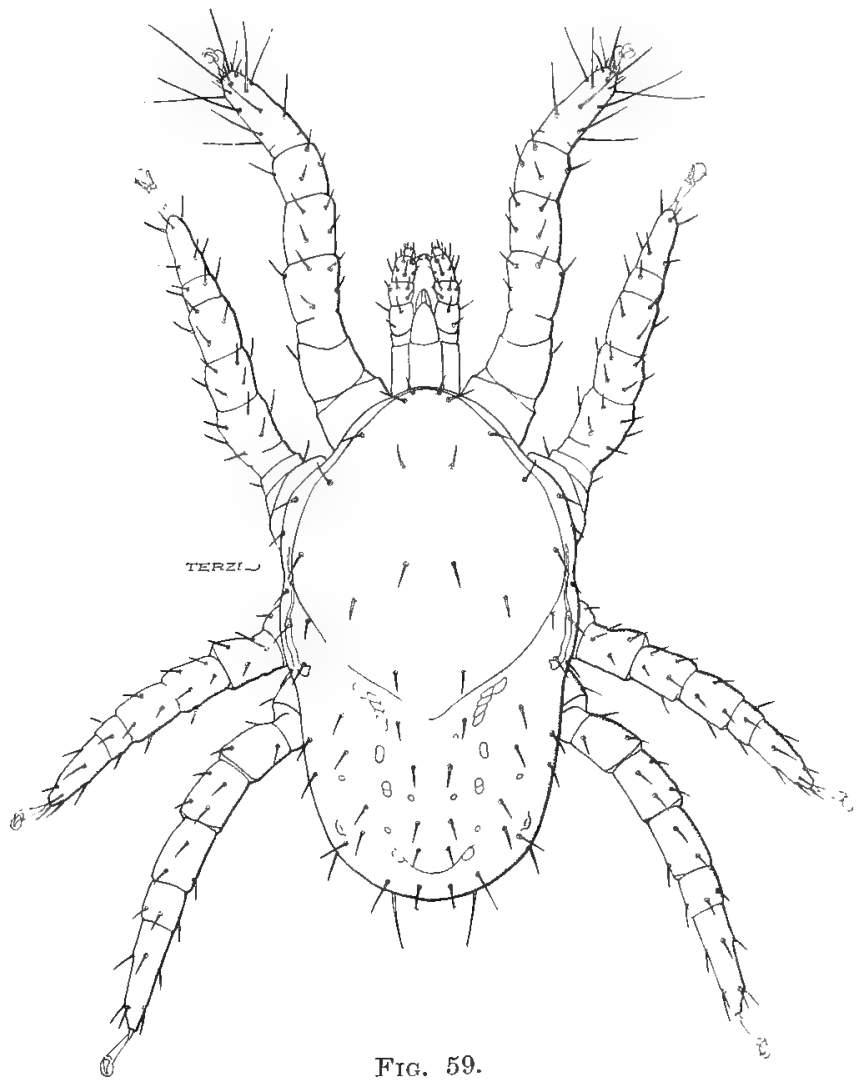

Dorsal view of first nymph (protonymph) of Dermanyssus gallinae (p. 87), $\times 146$. (Original.)

found in cheese and other substances. It is said by Shipley to occur frequently on the red grouse (Lagopus scoticus).

Glycyphagus domesticus, De Geer, 1778.

C. J. Davies records the presence of a Tyroglyphid mite in the ear of tame rabbits. The mite has been determined by A. W. N. Pillers as Glycyphagus domesticus, De Geer (fig. 38). 
Sub-order PROSTIGMATA.

\section{Fainiy TROMBIDIIDAE.}

Sub-Family C'Heyletinae.

Many of the mites in this family have the palpi greatly enlarged. The male sexual orifice is often situated dorsally.

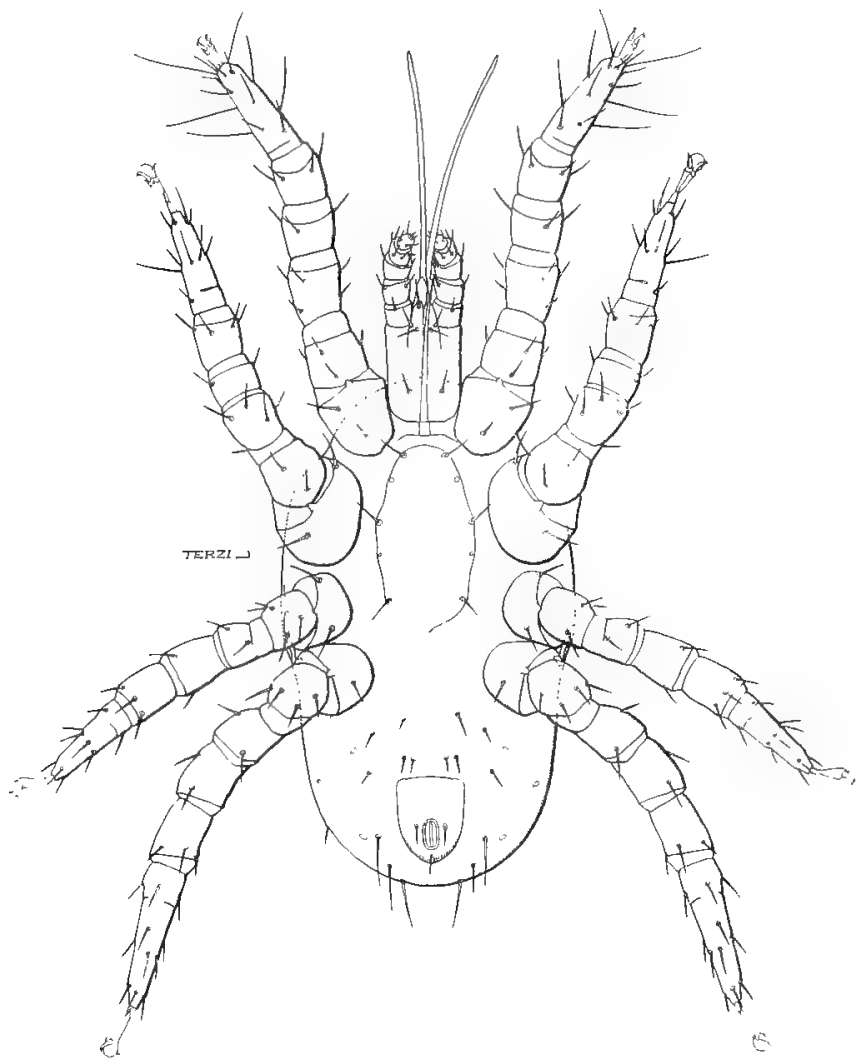

FIG. 60 .

Protonymph of Dermanyssus gallinae (p. 87), from below, $\times 146$.

(Original.)

Some of the Cheyletinae (Cheyletus, etc.) are free-living, predatory forms, being found amongst detritus and elsewhere preying on Tyroglyphid mites or other small arthropods, or they may occur on birds or mammals, either preying on the Analgesid or Listrophorid 
mites of those animals, or being sometimes themselves parasitic or pilicolous (Psorergates fig. 39 a, Myobia fig. 39 b, etc.).

Genus Cheyletiella, Canestrini, 1886.

In the genus Cheyletiella the palp is stout, ending in a prehensile claw, used to grasp the feathers or hairs of the host.

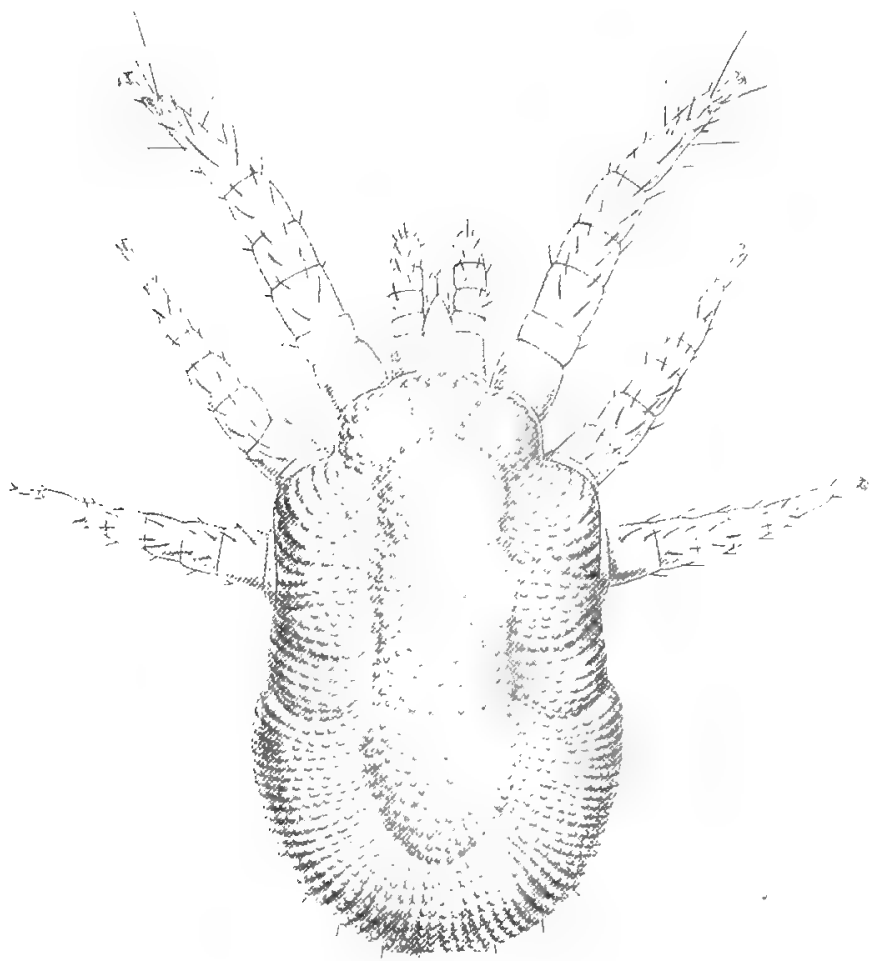

H., ring des

FIG. 61.

Larva of Dermanyssus gallinae (p.87), $\times 154$; drawn from living specimens. Note the minute conical tooth at posterior end of body used for piercing the egg-shell. (Original.)

Cheyletiella parasitivorax, Mégnin, 1878.

Apparently C. parasitivorax (fig. 40) is the only species that lives on mammals. It can readily be distinguished from the other members of the genus by the absence of claws, which have disappeared, for there are only combs at the end of the feet. 
The fur of the rabbit and hare is the normal habitat of this species. It is said to feed on the minute pilicolous Acari (Listrophorus, etc.) found on these rodents. In 1917 specimens of this mite were found by the author on a domestic cat in London. Cheyletiella parasitivorax has also been observed more recently on cats in Denmark by Lombolt and others.

Several other species of Cheyletiella are found upon birds.

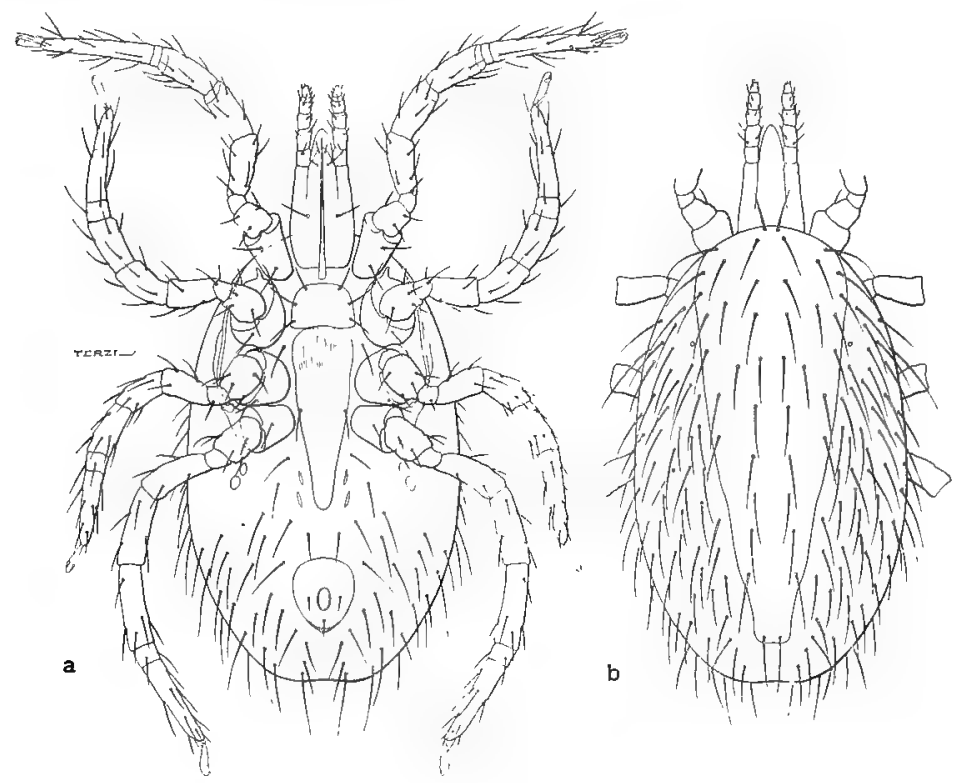

FIG. 62.

Dermanyssus muris (p. 87), $\times 40$,- A widely distributed parasite of rats. (a) Ventral aspect. (b) Dorsal aspect.

(After Hirst, Bull. Ent. Res. 1914.)

Genus Syringophilus, Heller, 1880.

Body very elongated and furnished with a number of long hairs. Chelicerae stiliform. Palpus and first leg normal, not being modified to form clasping organs. Feet with two claws and also with two combs, each composed of a series of setae.

Syringophilus bipectinatus, Heller, 1880.

(Figs. 41 a and 42 a.)

Body very elongated, the female being almost vermiform in shape, but the male somewhat shorter and stouter. 
This mite lives inside the quills of the feathers of the fowl, and is often present in great numbers. It is said to feed on the internal cones of the feathers. It occurs both in Europe and North America.

Syringophilus columbae, Hirst, 1920.

$$
\text { (Figs. } 41 \mathrm{~b} \text { and } 42 \mathrm{~b} \text {.) }
$$

Closely allied to the preceding, but there are only two quite short hairs on the front end of the anterior scutum, and the modified
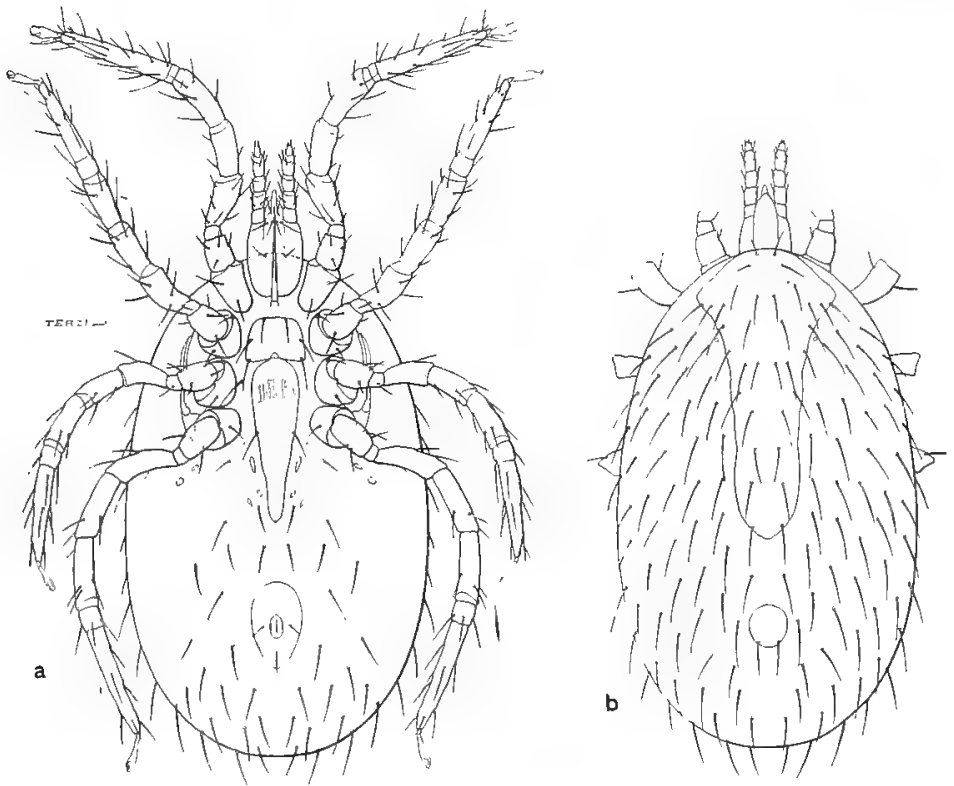

FIG. 63.

Dermanyssus sanguineus (p. 87), $\times$ 39. (a) Tentral aspect. (b) Dorsal aspect. (After Hirst, Bull. Ent. Res. 1914.)

hair on each side of the claws of the feet is nuch wider, being scalelike. A smaller species than $S$. bipectiuctur.

$S$. columbae lives inside the quills of the feathers of the domestic pigeon.

Genus Cheletoides, Oudemans, 1904.

Differing from Cheyletus in the absence of the comb from the chelicerae (mandibles). 
Cheletoides uncinata, Heller, 1880.

A much less elongated form than the two species of Syringophilus figured above. It lives in the quills of the feathers of the peacock (Pavo cristatus).

Sarcopterinus, Railliet, 1893.

Surcopterinus (= Harpirhynchus) nidulans, Nitzsch, 1818, lives in colonies in the follicles of the feathers, and gives rise to tumours

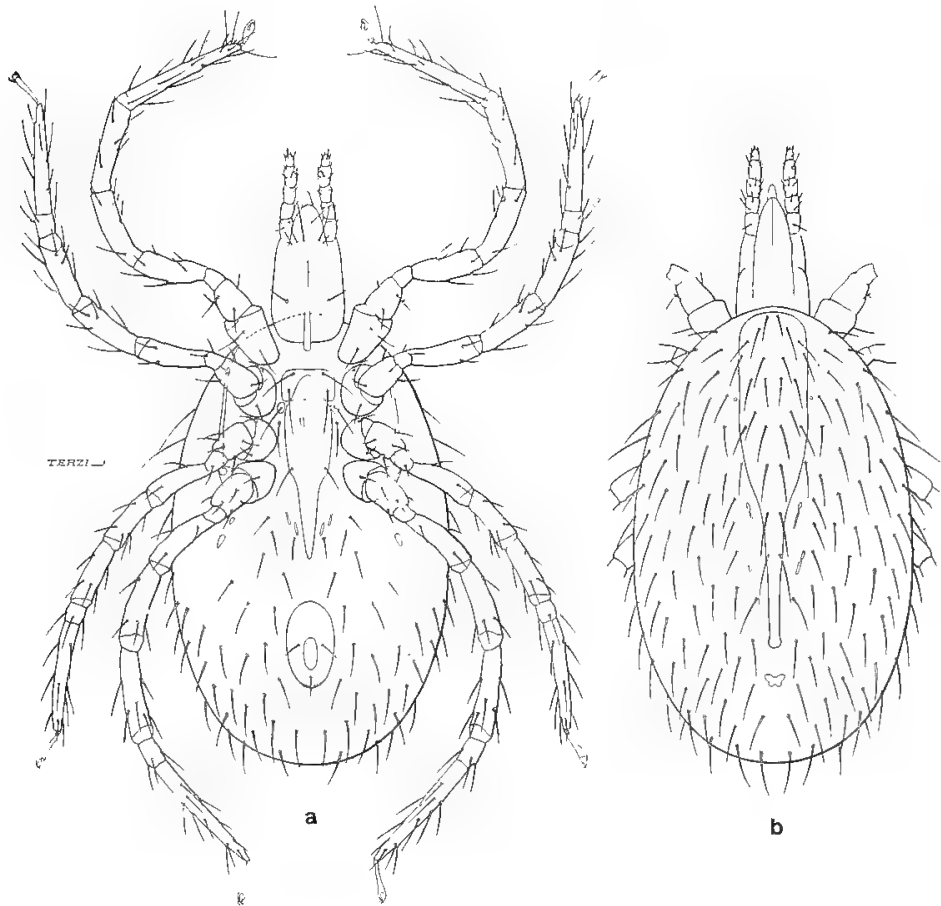

Fig. 64.

Dermanyssus aegyptius (p. 87), $\times 47$. (a) Ventral aspect. (b) Dorsal aspect. (After Hirst, Bull. Fnt. Res. 1914.)

or cysts in the skin. It occurs in a number of birds, including pigeons.

Sub-family Eupodinat.

Genus Tydeus, C. L. Koch, 1842.

Tydeus nolestus, Moniez, 1889.

This mite is described by Moniez as occurring in very large 
numbers for many years at an isolated farm in Belgium and causing great irritation by its bite to human beings and domestic animals (dogs, cats, fowls, guinea-fowl, and ducks). It is supposed to have been imported in guano from Peru. Fig. $4: 3$ of this mite is drawn from some of Moniez' original preparations now in the collection of the Faculty of Medicine of the Paris University.

Harvest Bugs (Leptus, etc.)

Harvest bugs are the larval forms of various Trombidid mites.
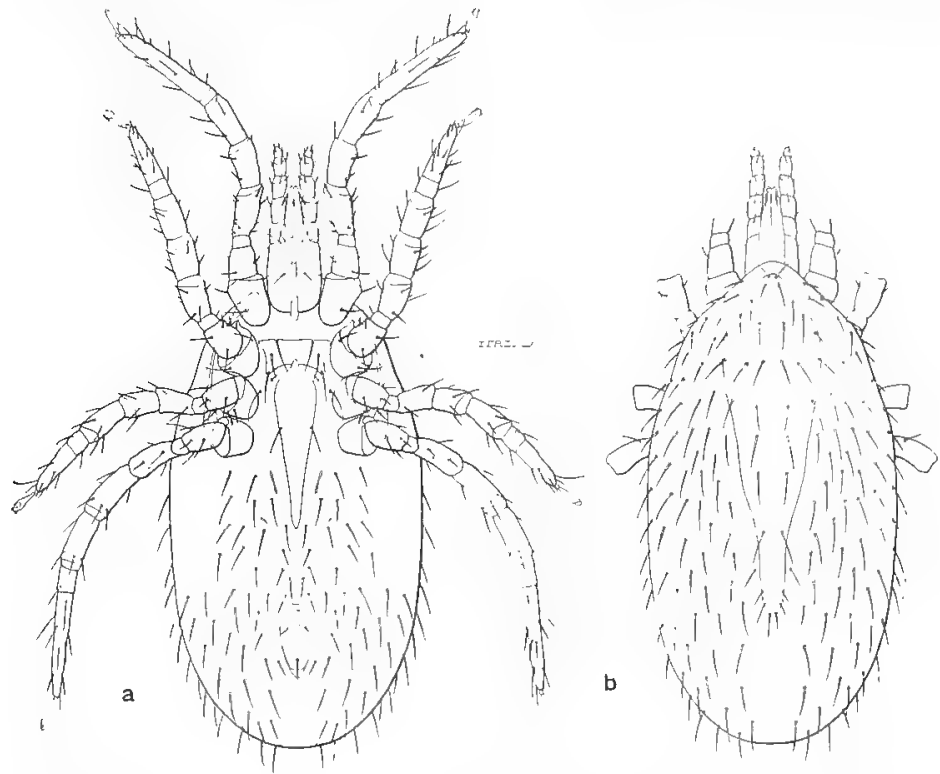

FIG. 65.

Liponyssus bacoti (p. 89), $\times$ (44. - A widely distributed parasite of the brown rat, sometimes attacking man. (a) Ventral aspect.

(b) Dorsal aspect. (After Hirst, Bull. Ent. Res. 1914.)

Owing to the fact that the adult stage is usually not known, it is necessary to allot provisional specific names to these larval mites.

Both wild and domestic animals are sometimes molested by harvest bugs. For instance, cats and dogs are often attacked during the warmer seasons of the year by our common Leptus (Trombicula?) autumualis, Shaw. According to Oudemans, Metathrombidium poriceps, Oudemans, also attacks dogs. Harrest bugs also molest man, horses, cattle, sheep, and goats. Similar mites have also been found on domestic poultry both in England and on the 
Continent; they are said to be very injurious to young chickens in the United States, sometimes causing death when present in large numbers. Two of the forms occurring on Ameriean poultry are figured in this pamphlet (figs. 44 and 45).

Another larval Trombidiid mite (Leptus (Microtrombidium?) guineense, Bruyant and Joyeux, 1913) occurs on poultry and monkeys at Kouroussa on the Niger in Upper French Guinea.

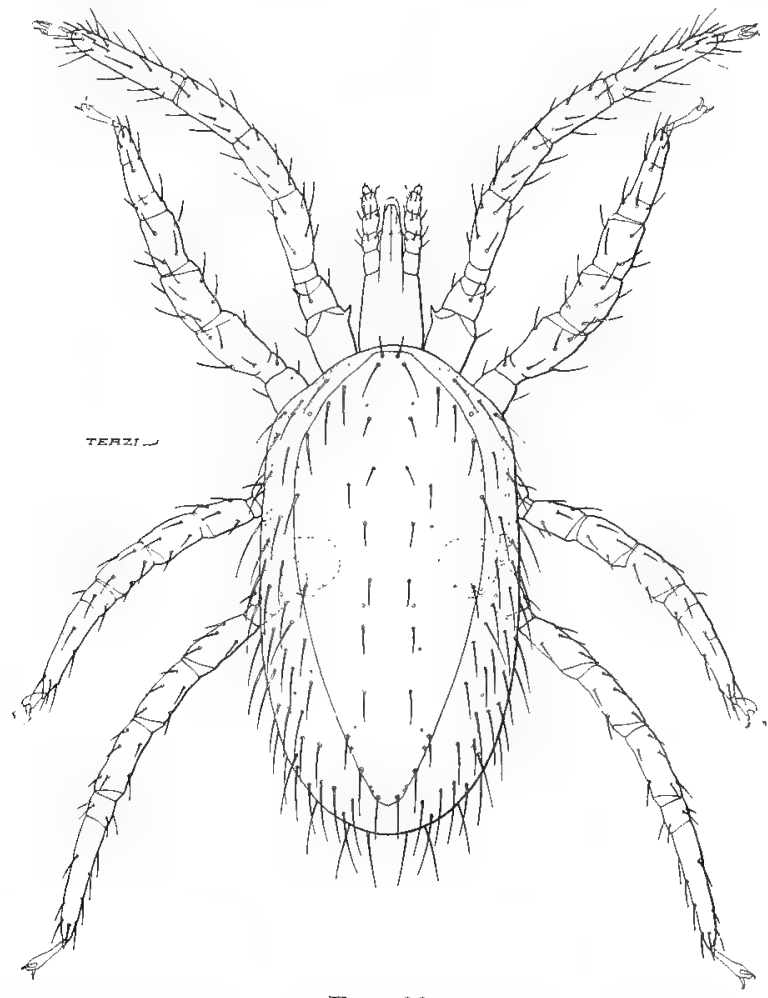

FIG. 66.

Liponyssus bursa (p. 89).-A fowl mite with a wide distribution in the warmer regions of the world. Dorsal view of female, $\times 100$. (After Hirst, Bull. Ent. Res. 1915.)

SUB-ORdER VERMIFORMIA.

\section{FaMily DEMODICIDAE.}

These mites are allied to the Cheyletinae (Prostigmata), especially to the genus Psorergates, Tyrrell, the species of which, like 
Demodex, are internal parasites, but are very different in shape, being almost circular in outline. Demodex agrees with $P$ sorergates and certain other Trombidiid mites (Myobia, etc.) in having the sexual aperture of the male on the dorsal surface, and also in the structure of the appendages of the larvae and nymphs which are quite rudimentary, merely consisting of an epimeron supporting a circular disc crowned with minute denticles (fig. 52). It is probable, therefore, that the Demodicidae are descended from pilicolous mites like Myobia, living at the base of the hairs of the host, and have subsequently become internal parasites, the very small size and elongation of the body being special adaptations to this mode of life. Besides the forms of Demodex mentioned below as causing skin trouble in domestic animals, Demodex occurs in man, bats, hedgehogs, moles, badgers, foxes, deer, rabbits, field mice, rats, house mice, etc.
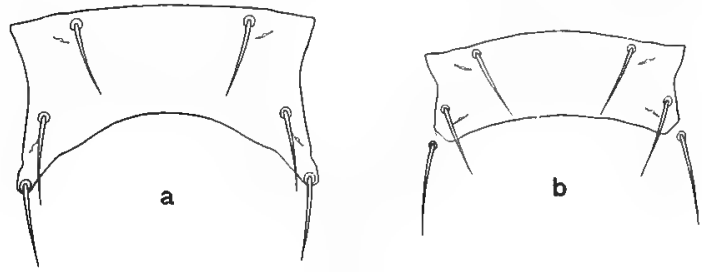

FIG. 67.

(a) Sternal plate of Liponyssus bursa, i (p. 89). (b) Sternal plate of L. sylviarum, \&. (Original.)

Genus Demodex, Owen, 1843.

Demodex canis, Leydig, 1859.

(Fig. 48.)

An elongated species, usually more than six times as long as wide. Spinule on capitulum very short and pointed.

$D$. canis is present in the skin disease called demodectic or follicular mange, a very serious complaint which is most difficult to cure. In typical cases the mites are found in enormous numbers, and are associated with a bacterium (Staphylococcus pyogenes albus or some allied form). The mite plays an important part in the disease by preparing the ground for the invasion of the bacterium by dilating the follicles and sweat glands, and possibly also carries and introduces the germ. The clinical symptoms of follicular mange vary very greatly; sometimes it assumes a pustular form characterised by numerous pustules accompanied by various crusts, etc.; in other cases it is a squamous affection with numerous epidermal pellicles, and sometimes the irritation is not very great 
in this variety. There is also a form of the disease with circular patches accompanied by large pustules. In a typical case there are small hairless patches, together with reddish pimples and pustules, skin hot and thickened in the affected places, etc. Dogs suffering from follicular mange have a characteristic odour which is very fonl and disgusting. The complaint can easily be confused with sarcoptic mange and also with certain fungoid affections, but the presence of the mites in large numbers is a distinguishing feature. (For a more detailed account of the structure of the mite and of the symptoms see Hirst, Studies on Acari No. 1. The genus Demodex, Owen, 1919, 44 pp., 13 pls., and 4 text-figs.).

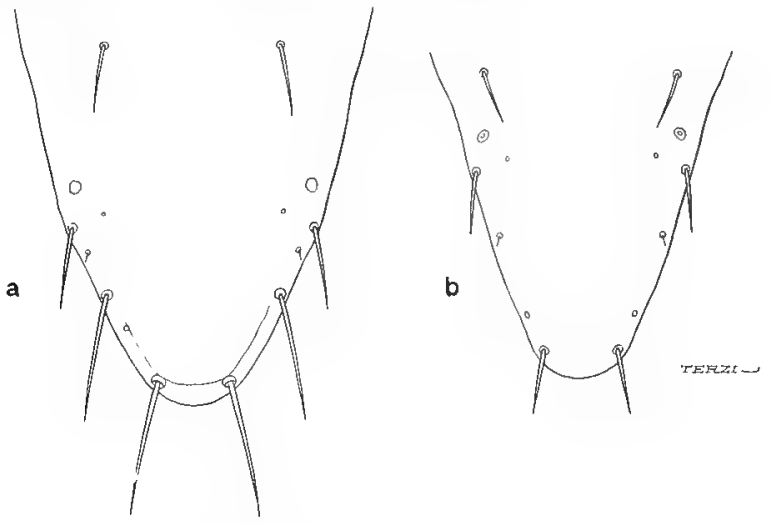

FIG. 68 .

(a) Posterior ent of clorsal shield of Liponyssus bursa, $\$$ (p. 89).

(b) Posterior end of clorsal shield of L. sylviarum, i. (Original.)

Demodex equi, Railliet, 1895.

(Fig. 49.)

The Demodex found on the horse is a rather wide species, the width being about a third of the total length. Spines on capitulum slender, rod-like, and blunt at the end.

Demodex equi is often present in horses which are apparently free from disease. It seems clear, however, that this species cancause a distinct pathogenic condition of the skin, characterised either by pruritus, varying greatly in intensity, or by definite lesions; these symptoms may occur together or separately. The clinical effects are as follows:- The coat is poor, with the hair very sparse in places, and there are peculiar bare-looking spots (rather like the marks made by the bites of horse-lice) occurring chiefly where the hair is 


\section{Mites Injurious to Domestic Animals.}

short; the hair on the spots is very thin, but not entirely absent. This disease usually commences on the saddle or neck of the animal. It does not appear to be at all infectious. The disease may also occur in a pustular form. The Demodex of the horse is often found in skin complaints due to other causes, especially in sarcoptic mange.

Williamson and Oxspring (Vet. Journ., lxxvi, p. 376, 1920)

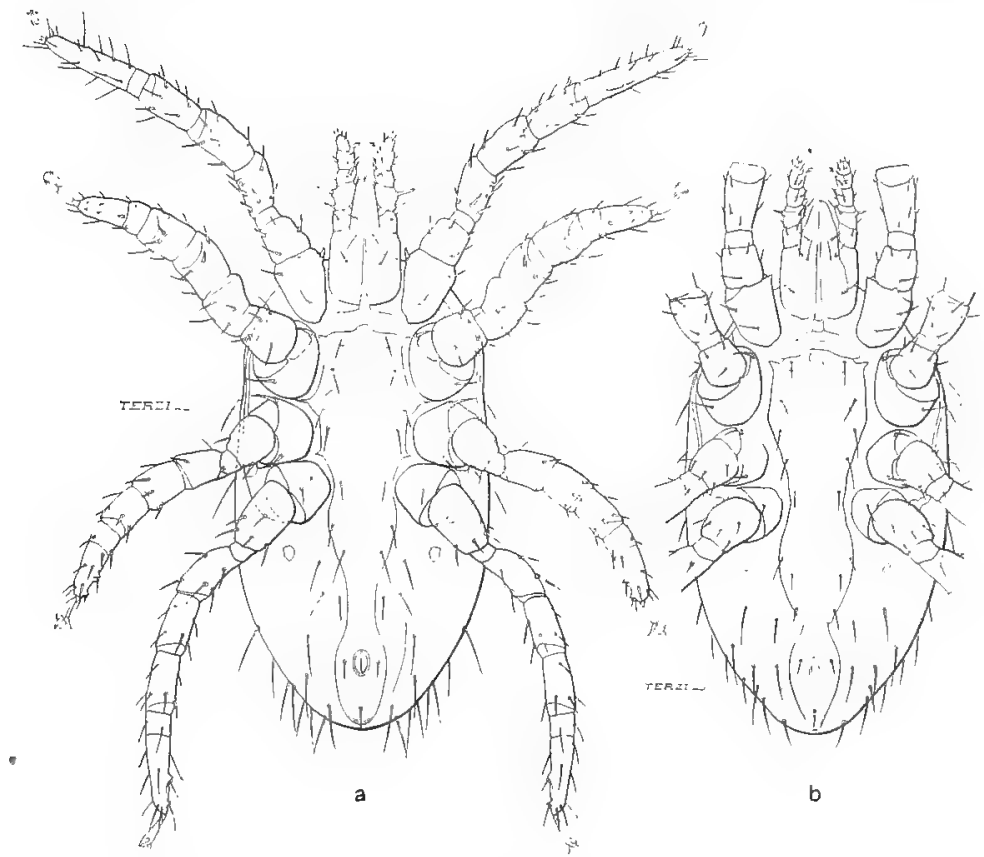

FrG. 69.

(a) Liponyssus bursa (p. 89), z, from below, $\times 92$.

(After Hirst, Buil. Ent. Res. 1915.)

(b) L. sylviarum (p. 90), o, from below, $\times 110$. (Original.)

state that in no case does demodectic mange of the horse show such marked symptoms as are commonly met with in the dog, but the majority of cases show obvious lesions which one would be far from justified in neglecting. There seem to be two stages in the disease. In the first stage, which includes the most benign and usually the more recently infected cases, there is no pustular formation, but there is always very strong pruritus. Certain areas of the skin are more irritable than others; these are generally on the neck, 
withers and croup the lower parts of the belly being rarely affected at this stage. The lower third of the neck is the usual site of origin. Little can be seen, but epidermal scales will be noticed to be more numerous than is usual on a well-groomed horse.

In the second or more advanced stage the presence of pustules is the most striking symptom. Cutaneous irritation is very much less marked, but a certain thickening of the skin will always be noticed.

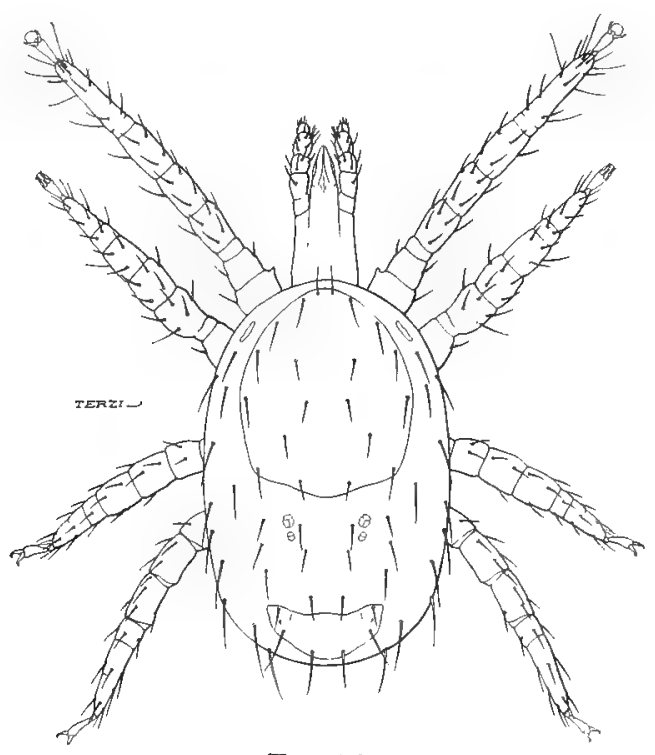

FrG. 70.

Protonymph of Liponyssus bursa (p. 89), dorsal aspect, $\times 101$.

Demodex phylloides, Csokor, 1879.

(Fig. 50, c and d.)

The Demodex of the pig is rather wide, the female being only about three and a half times as long as the width of the cephalothorax; the posterior end of the body is abruptly narrowed so as to form a short tail. Tubercle on capitulum very short and inconspicuous

D. phylloides causes a pustular skin disease in pigs, the pustules varying from a grain of sand to a walnut in size. They are often very numerous, and may be situated close together; sometimes they become confluent, and may rupture and cause sores and ulcers on the skin. Large numbers of the parasites are present in these 
pustules. The parasites are only found in places where the skin is fine in texture. The disease usually spreads from the snout, over the neck, the under part of the chest and abdomen, and over the flanks and inner parts of the legs. Some of the pustules are embedded deeply in the skin. In the pig, demodectic mange spreads very slowly, and only a few animalsi $n$ the herd are infected. Usually the general health of the animals is not affected.

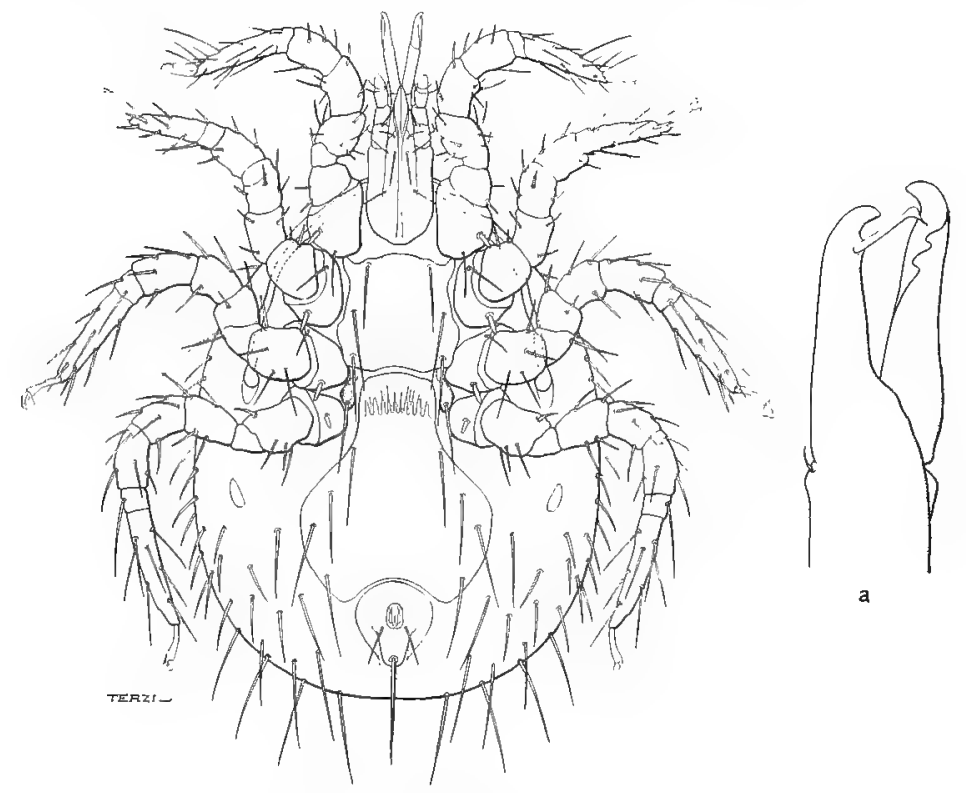

FIG. 71 .

Laelaps echidninus (p. 91).-A widely distributed parasite of the brown rat. Female, from below, $x 66$. (a) Chelicera. (After Hirst, Bull. Ent. Res. 1913.)

\section{Demodex bovis, Stiles, 1892.}

\section{(Fig. 51.)}

A fairly wide species, the female being usually from three to three and a half times as long as wide. Abdomen distinctly pointed at the end, especially in the male.

The demodectic mange of cattle has been reported from Nyasaland and the Belgian. Congo. Nodules or pustules varying in size from the head of a pin to that of a fowl's egg are present on the skin, occurring principally round the ears, on the sides, shoulders, 
intercrural space, ete. Numerous specimens of Demorlex in various stages of development are to be found in the cheesy or fluid contents of the nodules. The pustules or nodules may be situated in the thickness of the skin instead of on the surface. A large number of animals in a herd are sometimes found to be suffering from demodectic mange; hence it would seem to be infectious. According to Van Saceghem, the general health does not usually secm to be much affected. It is probable that the more serious cases of disease in cattle attributed to Demodex by Geoffroy and one or two other

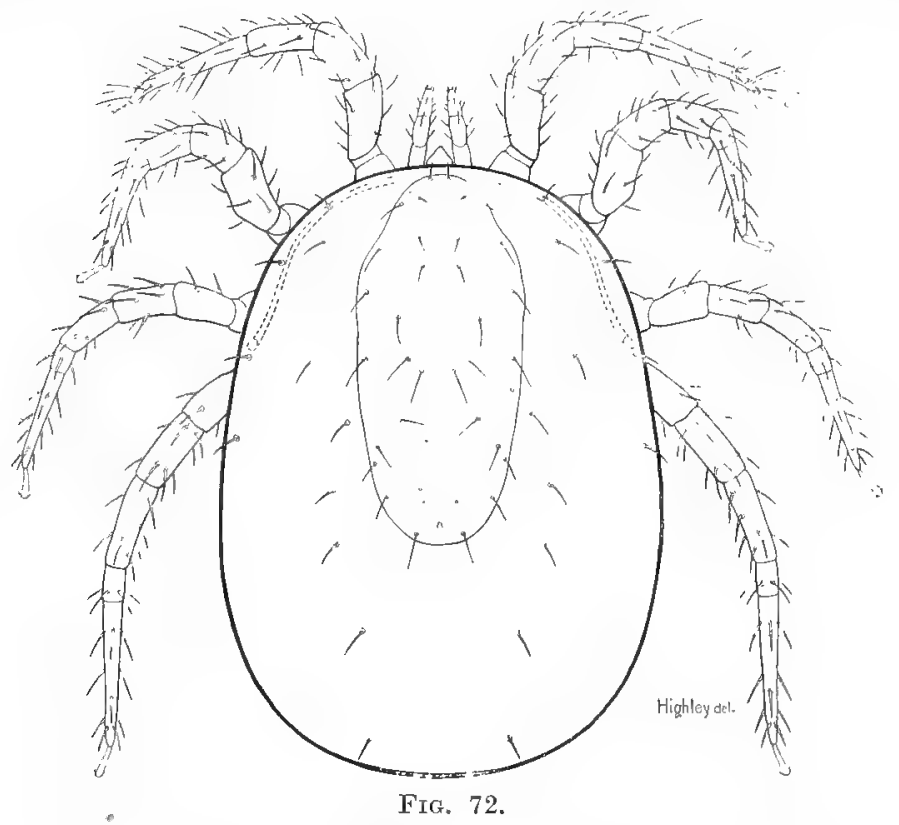

Raillietica auris (p. 91).-A Gamasid mite living in the eas of cattle. Dorsal view of female, $x 47$. (Original.)

observers, are really due to infection with some bacterium. Stiles states that the damage to the hides due to the enlarged holes caused by Demodex bovis lessens their value very considerably. The disease scems fairly common in the United States.

Demodex canis, var. ovis, Railliet, 1895.

$$
\text { (Fig. } 50 \text { a.) }
$$

The Demodex of the sheep is a slender, elongated form very similar to $D$. canis (and perhaps, indeed, the same species), but 
slightly shorter and with the capitulum rather wider. Spinule on capitulum as in $D$. canis.

Probably this form is a common parasite of sheep, but apparently it does not usually give rise to disease.

Dr. W. Klein has described, however, a serious form of demodectic mange occurring in sheep in Germany. Two large flocks were affected, nearly every sheep in one flock of six hundred seemed to be suffering from the complaint, the fleece being torn and missing

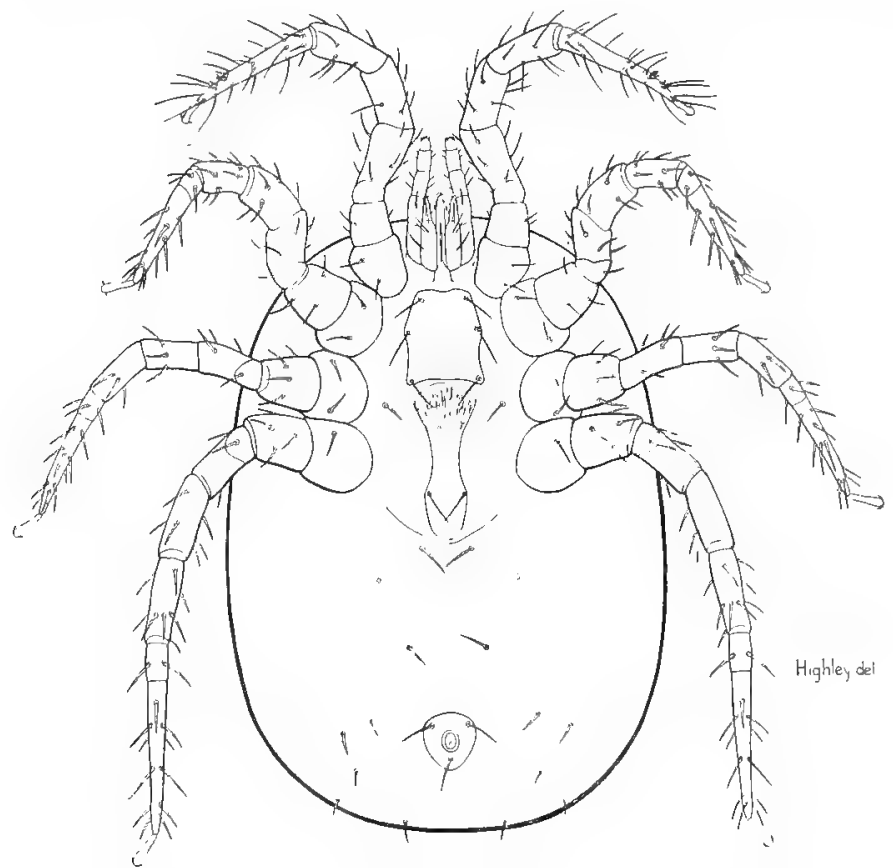

Fir. 73.

Raillietia auris (p. 91). - Ventral view of female, $\times 47$. (Original.)

or hanging loose in places. In advanced cases the animals were in moderate condition as regards nourishment, the wool had disappeared from the flanks, back, neck, and sides of the body, and the skin became hard as a board, thickened, and strongly wrinkled in the region of the neck. In the badly affected cases pruritus was intense. A slender form of Demodex, very similar to that of the dog, was present in numbers in these sheep.

Judging by the symptoms given by Klein one would imagine 
that Demodex was in this case associated with a skin complaint due to some other mite such as Sarcoptes or Psoroptes.

\section{Demodex cati, Mégnin, 1880.}

(Fig. 50 e.)

Body elongated, the abdomen of the male pointed at the end.

Demodex cati occasionally causes a skin disease very like that of the follicular mange of the dog. It may also be present in notoedric mange or in cases of parasitic otitis due to the mite called Otodectes. Specimens have been found in the skin of cats which were apparently quite healthy and showed no sign of any skin complaint.

\section{Demodex caprae, Railliet, 1895.}

The demodectic mange of the goat is characterised by little pustules varying from the size of a pea to that of a walnut. Sometimes they are placed on the surface of the skin, but in other cases they are situated deeply and are not visible on the surface. These pustules contain a greyish matter with numerous specimens of Demodex in all stages of development. The more deeply situated nodules are only visible when the skin is taken off (for they are situated on the inner surface); when the skin is being tanned holes appear at the places where the nodules occur and greatly lessen its value. In certain parts of Germany, according to Rissling, the goats of the race of Saanen are especially affected with this complaint; in many villages the majority of the goats have contracted it, whilst in other localities it is unknown.

\section{SUb-Order MESOSTIGMATA.}

\section{Fainly GaMasidat (Parasititae).}

These mites usually have rather strongly chitinized plates on the body. There is a well-defined linear peritreme running down each side of the body, the stigmal opening being placed close to the basal joint of the last pair of legs. Many of the mites of this family are free-living, often predatory forms; others attach themselves to beetles and other insects for transport; others are parasitic on small mammals, often living in the débris of the sleeping place or nest of the host, others are found on birds or reptiles.

The species of Halarachne live in the bronchial passages of seals, whilst those of the genus Pnezmonyssus inhabit little cysts or tubercles in the lungs of old-world monkeys. 
Genus Dermanyssus, Dugs, 1834.

This genus is chiefly characterised by the thin stylets (chelicerae) which are of considerable length in the female sex, being well adapted for piercing the skin of the hast (fig. 54). Only five species are known, two of them being found on birds and three on rats. One of the species found on birds (D. gallinae, figs. 55-61) is the common red mite of poultry and cage birds; the other $(D$. passerinus $)$ is a parasite of the common sparrow and apparently restricted to that host.

One of the species of Dermanyssus parasitic on rats (D. muris, Hirst, fig. 62), chiefly found on the black rat, is widely distributed, having been recorded from Egypt, Arabia, India, Ceylon, and

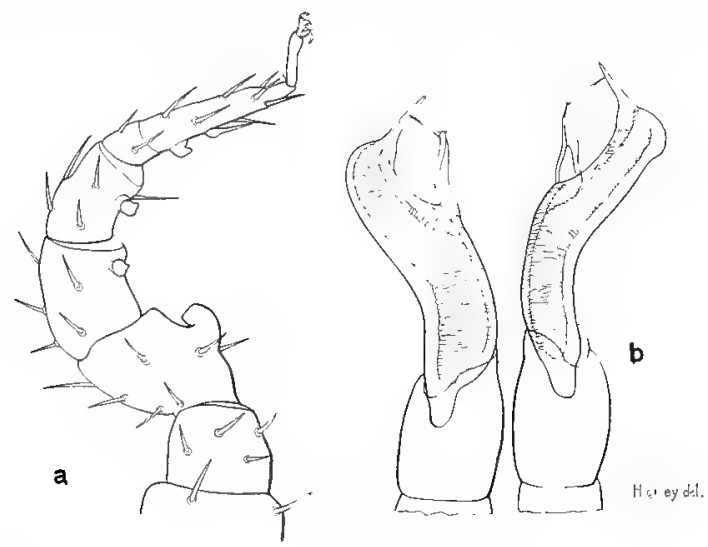

Frg. 74 .

Raillietia auris (p. 9I). (a) Second leg of male. (b) Chelicerae. of male. (Original.)

Formosa. The other two (D. sanguineus, Hirst, fig. 63, and $D$. aegyptius, Hirst, fig. 64) have so far been found only in Egypt.

Dermanyssus gallinae, Redi, 1674.

(Fig. 55-61.)

The colour of this well-known pest of poultry varies from whitish to dark red, according to the amount of ingested blood. The larva can transform itself into the next stage (first nymph) without taking any nourishment. The complete life cycle from egg to adult is said to take about seven days.

Dermanyssus gallinae is of considerable economic importance, being very abundant in many fowl-houses in Europe and North 
America. Both poultry and cage birds are greatly weakened by loss of blood due to its attacks. It is nocturnal in habits, coming out at night to suck the blood of the birds. During the day time the mites conceal themselves in crevices, under boards, and in similar obscure places. Sometimes they live in the hollow perchingbars of cages or in the ornamental tops of metal cages. They are capable of living many days without feeding. Red mites (presumably $D$. gallinae) have been proved by Mayer to transmit spirochactosis (Spirochaeta gallinarum) in canaries, but it is not certain whether infection is due to the bites of the Acari or to their being swallowed by the bird.

Bishopp and Wood point out that the mites can continue to infest the poultry houses long after the fowls have been removed. $D$. gallinae is able to live for a long time without sucking blood. In some test experiments made by the authors mentioned above some of the mites were still alive after being separated from the host for 113 days or more. Their tests showed that when the mites were supplied with a certain amount of moisture they lived longer than when kept under very dry conditions. The author has kept specimens of $D$. gallince in tubes and cardboard boxes without food, but with a little moisture supplied occasionally, and one or two mites were still living after eighty-two days.

Fowl houses infested with $D$. gallinae should be sprayed with crude petroleum either employed alone or diluted with kerosene at the rate of one part of kerosene to three parts of petroleum. Commercial carbolineum (a high grade anthracene oil) has been used as a spray with still better results in the United States. It is advisable to repeat the spraying after a month's interval. Creosote has also been successfully used against this fowl mite.

Solutions of commercial disinfectants made up to double the usual strength recommended for domestic use can be applied by means of a watering-can with a fine rose to the interior of the fowlhouse, the soil of the runs, dust bath, etc. If this be done weekly the parasites become reduced in number and gradually disappear.

D. gallinae is also found in the nests of sparrows, pigeons, swallows, wrens, and of a few other species of birds. Horses and other manimals are sometimes molested by this mite.

\section{Genus Liponyssus, Kolenati, 1859.}

The genus Liponyssus is characterised by the rather short mandibles (chelicerae), the fingers of which are separate and smooth or with obsolete teetl. The body is often bilobed posteriorly. 
There are a number of species of Liponyssus, most of them being parasitic on bats and rodents, a few on reptiles and on birds. T'wo species ( $L$. bursa and $L$. sylviarum) are parasitic on the domestic hen. Another species (L. bacoti, Hirst, fig. 65), is parasitic on rats, and is widely distributed in the warmer parts of the world, sometimes attacking man.

\section{Liponyssus bursa, Berlese, 1888.}

(Figs. 66, 67 a, 68 a, 69 a and 70 .)

The tropical fowl mite apparently replaces Dermanyssus yallinae in the warmer regions of the world. It is very widely distributed

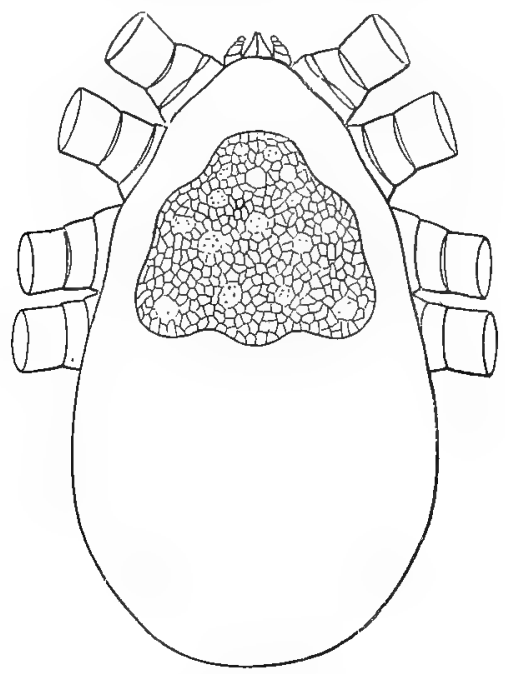

FIG. 75 .

Sternostomum rhynolethrum (p. 92).-A mite living in the nasal cavities of geese. Female from above. (After Berlese.)

in Africa, also occurring in Mauritius, the Comoro Islands, China, India, Texas, the Bahamas, Colombia, Buenos Aires, and in Australia. Sometimes it occurs in very large numbers on nesting hens. Several cases of this fowl mite attacking man have been recorded. L. bursa has been found on the common sparrow, and, like L. sylviarum, possibly it is conveyed from one locality to another by this host. When the name Dermanyssus gallinae is met with in reports by entomologists dealing with the parasites of the domestic fowl in tropical countries, it is probable that $L$. bursa 
is really the species concerned. Numerous batches of Gamasid fowl mites from tropical regions have been forwarded to the British Museum (Natural History), but, with the exception of a few examples from Palestine and from the Kenya Colony, and an example found on Gecinus vaillantii at Tangiers, there have not been any specimens of $D$. gallince amongst them. It would appear, therefore, that the European red mite of poultry does not thrive in tropical and sub-tropical countries.

$L$. bursa is closely allied to L. sylviarum, of which perhaps it is a variety.

Liponyssus sylviamm, Canestrini and Fanzago, 1877.

(Figs. 67 b, 68 b, and 69 b.)

Liponyssus sylviam is very closely allied to $L$. bursa, but has only a single pair of long hairs at the posterior end of the dorsal scutum instead of two pairs as in that species. There are only two pairs of hairs on the sternal plate instead of three. Ventral plate of male with a transverse line posteriorly in front of the anal plate, this line being absent in L. bursa. (Text fig. 69.)

This Gamasid mite oceurs on several kinds of birds in Europe, including sparrows and pigeons, but it is not a very common species in England. In the United States it has recently been found on sparrows and in their nests, and also attacking poultry in several localities. It sometimes spends its entire life cycle on the fowl, all stages being found amongst the feathers. Egg production is much reduced in birds infested by it. Fortunately, this parasite seems to have been introduced into only a few localities in the United States, and, owing to the prompt and energetic measures taken against it, has probably been stamped out.

Owing to the fact that this mite can live and breed on the fowl, it is necessary to apply some substance which will kill the mites without injuring the host. Fumigation by nitro-benzol has been successfully employed for this purpose at the Purdue University Agricultural Station, Lafayette, Indiana. This method should not be used in the case of laying hens, as the fumes affect the unlaid eggs to such an extent that they cannot be used for domestic purposes. Dusting with flowers of sulphur is also said to be a useful remedy.

The mite described by Mégnin in 1891, under the name Lophoptes patarims as causing a special acariasis in Paduan fowls, is possibly L. syleiarum.

Another species of Liponyssus (L. suffuscus, Railliet) is said to 
have been found on rabbits, but little is known akout the structure or habits of this mite.

Some of the mites of the genus Laelaps, C. L. Koch, are parasitic on rodents, moles, and other small mammals. One species (L. echidninus, Berlese, fig. 71) is parasitic on the brown rat and, like its host, is probably cosmopolitan; another species ( $L$. muttrlli, Hirst) is common both on the black rat and brown rat in tropical regions. The species of Hurmogrmmasts, Berlese, suck the

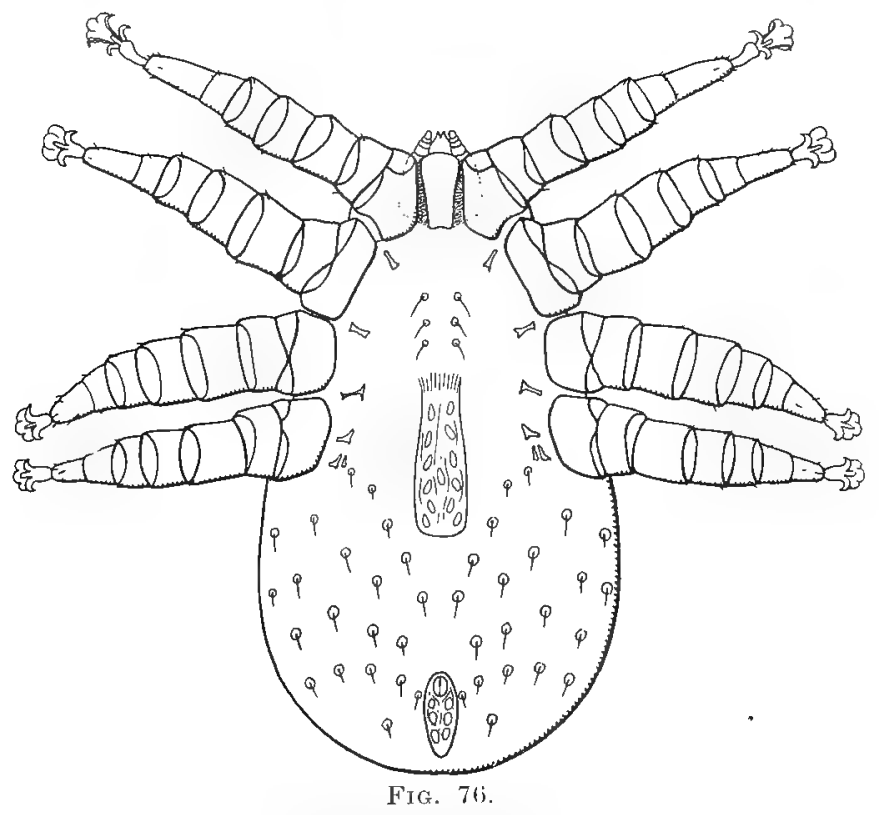

Sternostomum rhynolethrum (p. 92).- Female from below. (After Berlese.)

blood of various small mammals such as moles, field mice, etc.; and one species (H.oudemansi, Hirst) is found on the brown rat in this country.

Genus Rrillietiu, Trouessart, 1902.

Raillietia auris, Leidy, 1872.

(Figs 72-74.)

In general appearance this mite resembles a Dermanyssus or Liponyssus. Second leg of male very characteristic, being armed 
with knob-like protuberances, like those present in certain nonparasitic Gamasid mites (Gutuctsus, etc.). It measures slightly over a millimetre in length.

This interesting mite lives in the external ear of cattle, apparently feeding on the waxy secretions. It is found both in North America and Europe (France, Austria, etc.). In some localities it seems to be fairly common.

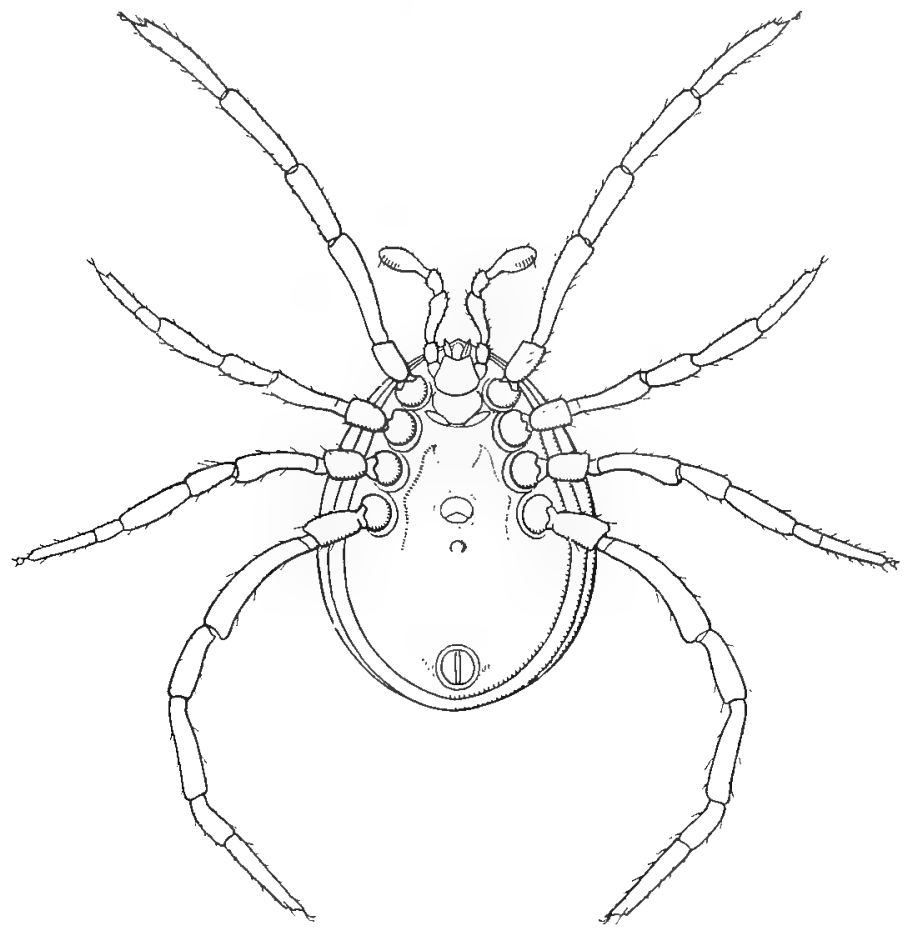

FIG 77.

Holothyrus sp. (p 93)., from below $\times 13$. (After Thorell.)

Gelnus S'teinostomum, Trouessart, 1895.

Sternostomum rhynolethrum, Trouessart, 1895.

(Figs. 75 and 76.)

This mite has been found living in the nasal cavities of geese in France. It feeds on the blood of the host and may set up severe inflammation of the nasal passages. Another species (Sternostomum 
cryptorhynchum, Berlese and Trouessart) is parasitic on the common sparrow. An allied mite (Ptilonyssus nudns, Berlese and Trouessart) occurs in the nasal cavities of the common sparrow, whilst others (Rhinonyssus, etc.) are parasitic in various birds both in Europe and elsewhere.

\section{FAMILY HOI,OTHYRIDAE.}

The Holothyridae are rather large reddish mites with the upper surface of the body convex and shining, the integument being hard.

According to some recent authors these mites should be regarded as forming a distinct family, but in general appearance, position of the stigmata, etc., they are very like Gamasid mites, and are regarded by some authors as being closely allied to that family.

Genus Holothyms, Gervais, 1842.

(Fig. 77.)

Holothyrus coccinella, Gervais, 1842.

This species lives in the Island of Mauritius. It secretes an irritant poison, and is sometimes swallowed by ducks and geese, causing their death ; for this reason it is called "touille canard" by the inhabitants. Children have suffered ill effects through putting the mite in their mouths, or from meddling with it and afterwards touching the mouth with the fingers. 


\title{
A P P E N D I X . \\ ON THE ACARINE DISEASE OF HIVE BEES.
}

\author{
SUB-ORDER HETEROSTIGMATA. \\ FAMIIY TARSONEMIDAE.
}

Genus Acarapis, Hirst, 1921.

The genus Acarapis is closely allied to Tarsonemus, from which it differs as follows:-Second and third legs of larval stage very short (almost rudimentary) and without either iclaws or sucker (figs. 82 and $83 \mathrm{c}$ ), whereas, in the larva of Tarsonemus, these legs are about as long as the first and are provided with paired claws and a sucker (fig. 84).

The female of Acarapis lacks the club-shaped pseudostigmata present between the first two pairs of legs in that sex in Tarsonemus, and the fourth leg is shorter and wider, being provided with more numerous hairs (in this last respect somewhat resembling the fourth leg of Scutacarus).

Acarapis woodi, Rennie, 1921.

(Figs. 78-83.)

For a long time the "Isle of Wight Disease" of bees was thought to be due to a protozoon parasite (Nosema apis). But Rennie, White, and Miss Harvey (Trans. Roy. Soc. Edinburgh, LII., 1921, pp. 737-779) have found a Tarsonemid mite constantly present in the thoracic tracheal tubes of bees suffering from this disease. Loss of the power of flight is one of the chief distinguishing features of "Isle of Wight" Bee Disease, and another is the great mortality that occurs amongst infected bees. "Crawling" bees are usually present in numbers in diseased stocks. According to Rennie crawling appears to be intermittent. Apparently on very warm days an excessive amount of crawling may occur, ridding the hive of the bulk of the heavily infected individuals and lowering the proportion of sick bees in the hive. New bees are being produced in large numbers at certain times of the year, and even if some of them become 
infected early in their adult life, they may continue to fly and work for a long time. A false impression of recovery from the disease may thus be conveyed. The mite has been found in workers, drones, and queens, but the young stages of the bee do not seem to harbour it. It also occurs sometimes in apparently healthy bees, but in these the disorder usually makes its appearance at a later date. In some instances, however, the mite seems to be present without causing the disease, and heavily infested bees may be capable of flight. All stages of the life cycle of the parasite are found in the tracheal tubes of the thorax and sometimes of the

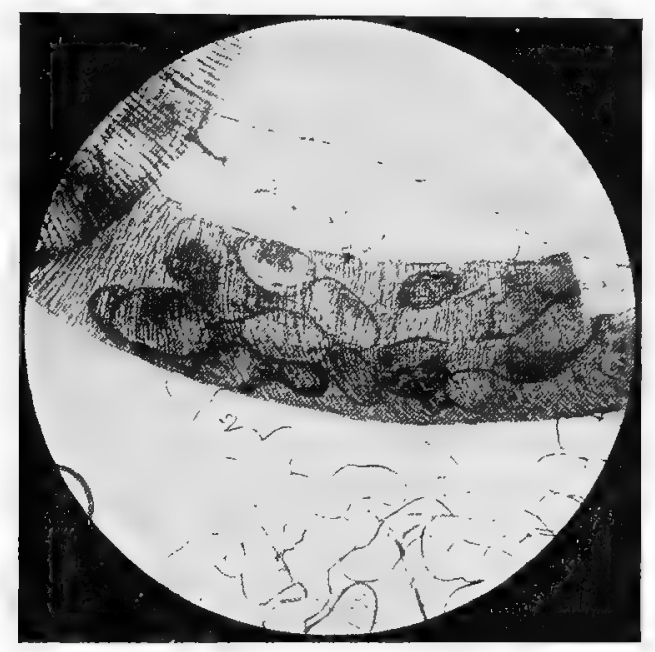

FIG. 78.

Tracheal tube of honey bee infested with Acarapis woodi.

(Photo by the Rev. G. H. Hewison.)

head, and apparently the mites are restricted to this part of the respiratory system. Acarapis woodi is oviparous, the eggs being of very large size, when compared with the mite itself, and beanor kidney-shaped. They are laid in the tracheal tubes of the host. The mite emerges from the egg in the form of a six-legged larva (fig. 82), which subsequently develops into the adult. Adult mites of either sex are frequently to be met with fully-developed but still enclosed in the larval skin. Apparently infection takes place through the thoracic stigmatal openings. The mites, no doubt, set up ill effects through blocking the tracheal tubes, and probably also through sucking the blood of their host. It has been suggested 
that the metabolic products of the mite may perhaps cause toxaemia (see "Bee World," October, 1920-April, 1921, p. 59). White has pointed out that pathological changes take place in the tubes infested by them; whilst the muscles concerned with flight also show degenerative changes. The tracheal tubes of bees are normally pale,

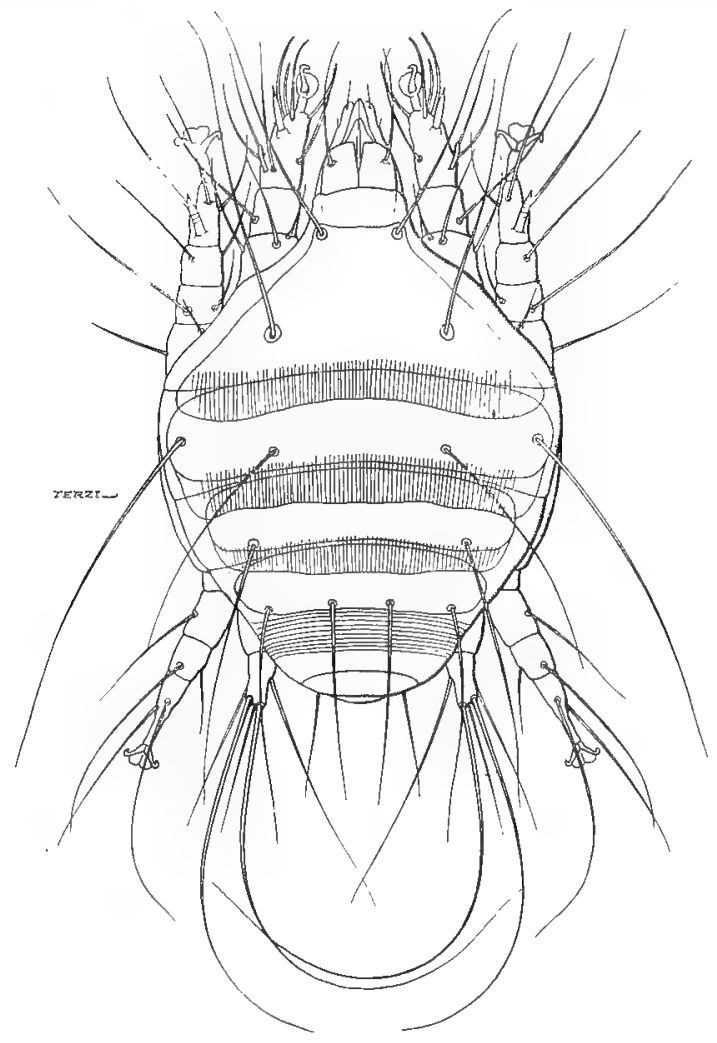

Fig. 79.

Acarris woodi.-Female from above, $\times 405$.

(After Hirst, Amn. Mag. Nat. Hist., June, 1921.)

but in advanced cases of the disease they become brownish or blackish, and this makes it easy to recognise the malady, for if the tracheae of a bee are discoloured the mite is invariably present. This change in the colour of the tracheal tubes is accompanied by hardness and brittleness of their walls. White has shown that if one of the thoracic stigmatal openings of a bee is closed with wax, the insect loses 
the power of flight and becomes a crawler. So far apparently Acarapis wood $i$ * has been found only in English bees. It is obvious that this mite has long been a specialised parasite of the honey bee or some allied insect, and it is very remarkable that its presence in the tracheal tubes has so long been overlooked by workers on the

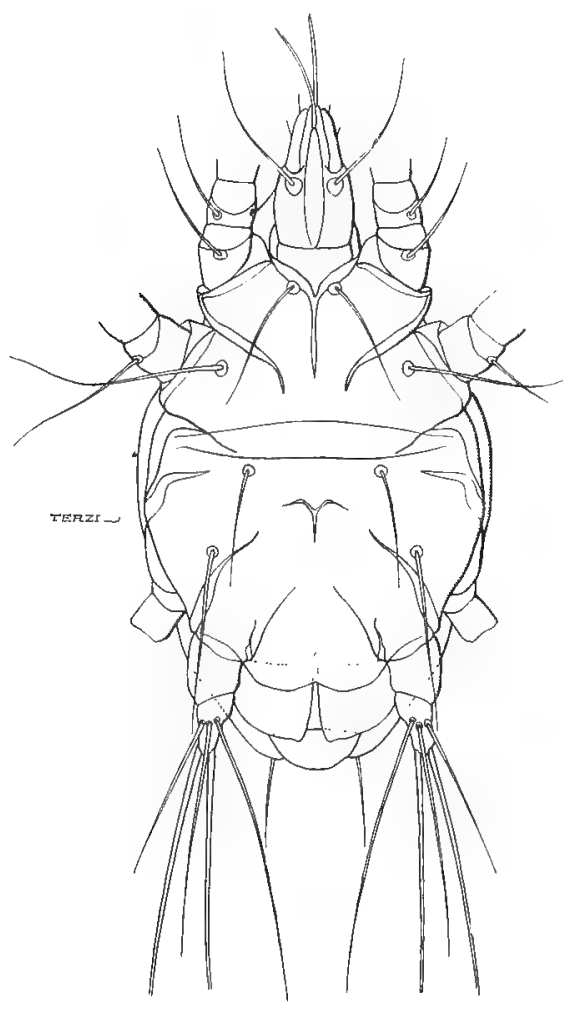

FIG. 80.

Acarapis woodi.-Ventral view of female, $\times 443$.

(After Hirst, Ann. Mag. Nat. Hist., June, 1921.)

diseases of bees. So far no one has succeeded in finding Acarapis as a parasite of any other insect, but the possibility that this is the case should be borne in mind. It is not known how infection

* According to Vitzthum, Dr. Ellinger of Weimar has reported that the disease has made its appearance in Germany also (Bayerische Bienenzeitung, April, 1921). 
takes place-possibly by bees visiting the same flower or drinkingplace, or perhaps the mite is introduced by strange bees or drones drifting into a hive, or is acquired by healthy bees whilst robbing an infected colony.

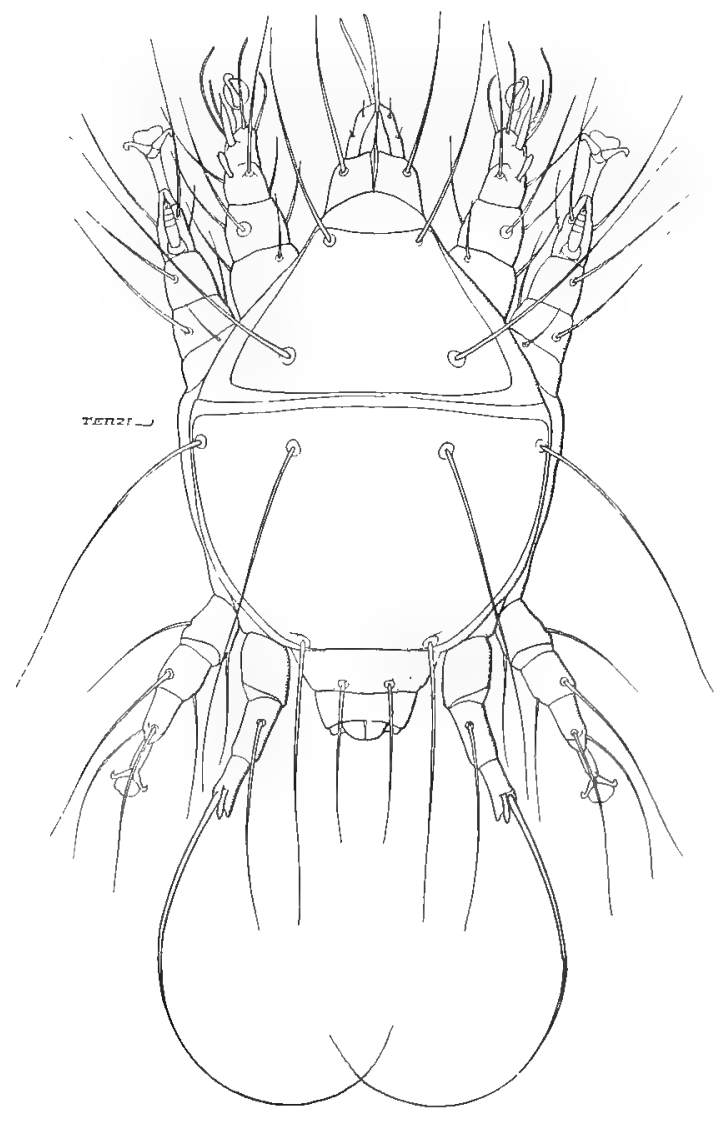

FIG. 81.

Acrerapis woodi.-Dorsal view of male, $\times 650$. (After Hirst, Ann. Mag. Nat. Hist., June, 1921.)

There is no nymphal stage either in Acarapis or in Tarsonemus, this stage being entirely suppressed. It is probable, therefore, that the disease spreads by transference of adult mites. After the death of the bee the mites continue to live for several days, and the great majority of them seem to die without leaving the body of 
the host. Occasionally a few adult female mites may be seen wandering about on the dead body of their host. Rennie states ("Bee World," May, 1921, p. 144) that adult females of the mite may be found creeping amongst or clinging to the hairy covering of infected bees, and that when bees carrying such mites move about in the cluster, the mites are transferred from bee to bee. Fertilisation had, no doubt, already taken place before the female mite left the inside of the tracheal tubes of its host. It is too early as yet to be able to estimate the exact degree of importance
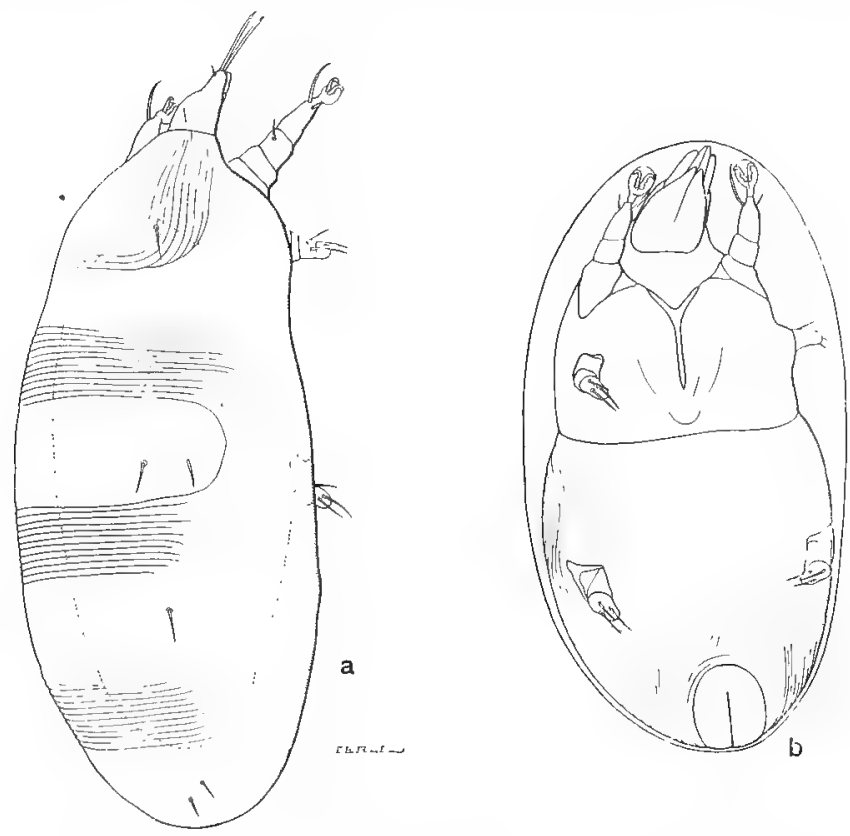

FIG. 82.

(a) Larva of Acarapis woodi. (b) The same in the egg-shell. (After Hirst, Ann. Mag. Nat. Hist., June, 1921.)

of the discovery of this Tarsonemid mite as an internal parasite of the honey bee. It is probable, however, that it is the causal agent of the deadly malady usually called "Isle of Wight Bee Disease." As mentioned above, the protozoon Nosema apis was once thought to be the cause of this disease, but apparently the disease set up by it is a distinct one. The possibility that other diseases with similar symptoms may occur should also be borne in mind, for bees are sometimes found crawling and dying in large 
100 Mites Injurious to Domestic Animals.

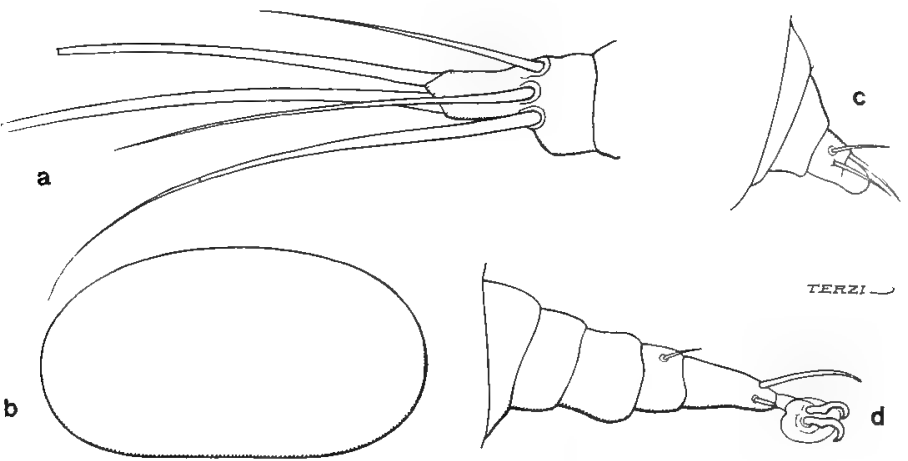

Fig. 83.

Acarapis woodi. (a) Fourth leg of female. (b) Egg. (c) Posterior leg of larva. (d) First leg of larva.

(After Hirst, Ann. Mag. Nat. Hist., June, 1921.)
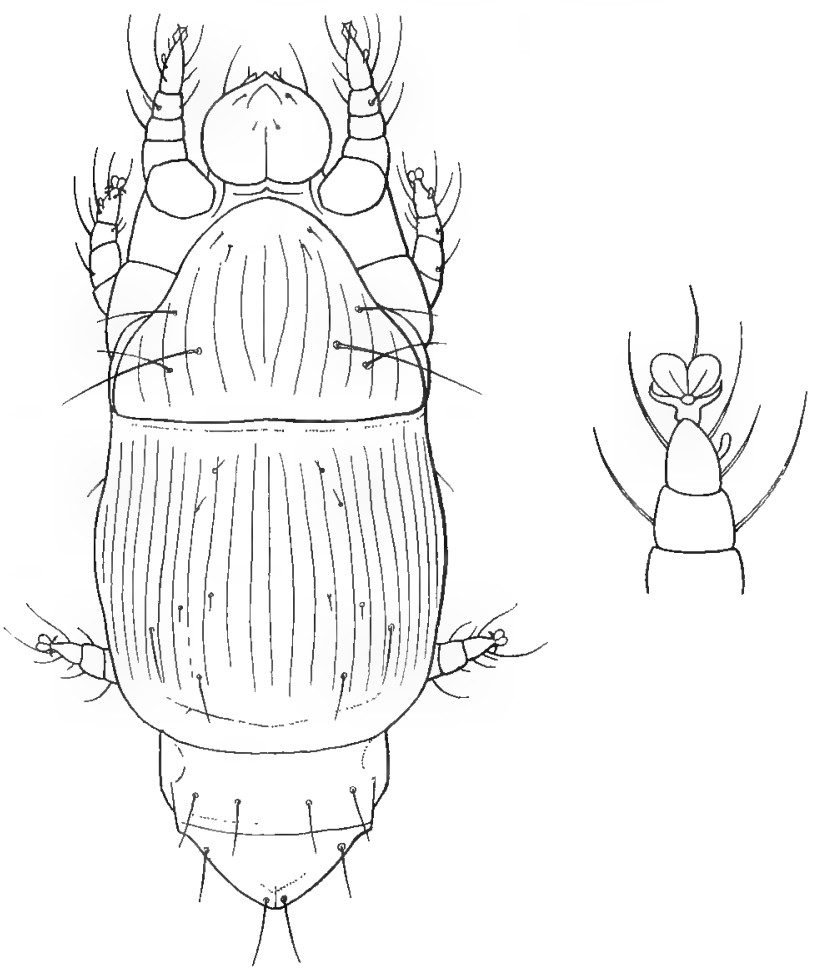

Fra. 8.4.

Larva of Tarsonemus, and end of second leg of same. (After Reuter.) 
numbers when neither Acarapis nor Nosema can be found in the stock.

Besides Acarapis woodi, which is an internal parasite, examples of Tarsonemus occasionally occur on bees. A species found on British hive bees has been described by Dr. Rennie under the name Tarsonemus apis (fig. 85). The author has found specimens of Tarsonemus on Apis dorsata and Apis florealis (both Indian
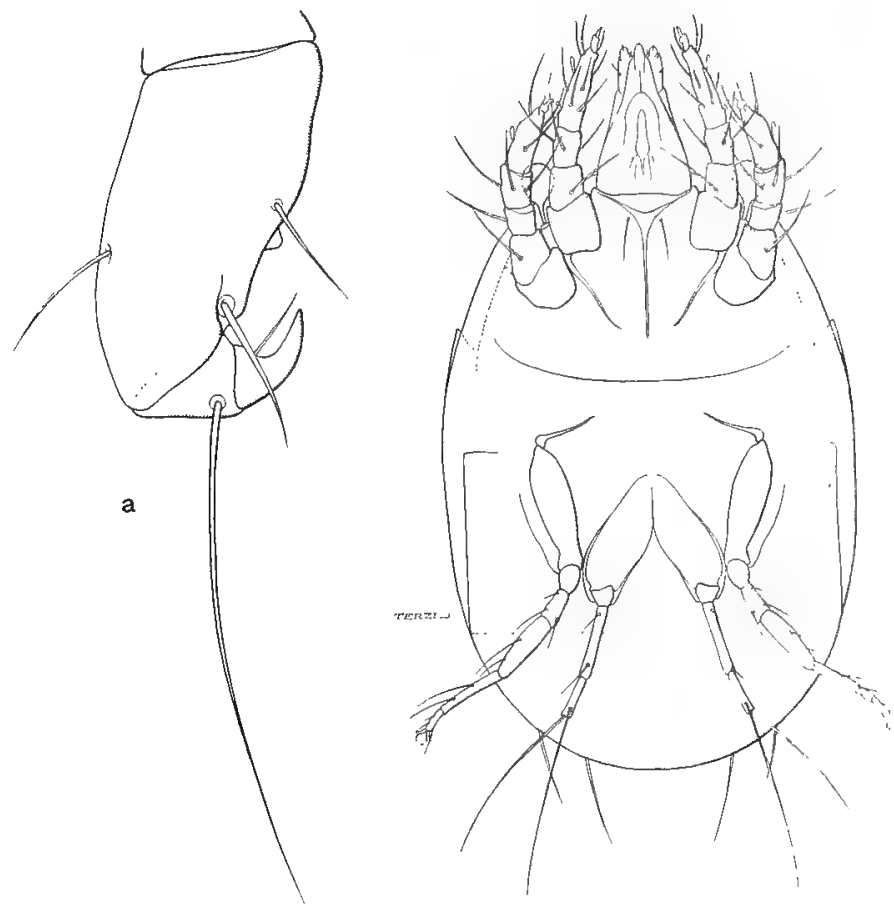

Fro. 85.

Tarsonemus apis.-Ventral view of female. (a) Last leg of male of same. (Original.)

species of bees) and on Apis mellifica, var. indica (from Singapore). It is probable that the presence of these mites of the genus Tarsonemus (sensu stricto) on bees is due to the migratory instinct, the bee being merely used for the purpose of transportation, thus increasing the area of distribution of the mite. It is improbable that pseudoparasites of this type are injurious to the health of the bee, whereas Acarapis is undoubtedly parasitic and very injurious to its host. Specimens of Tarsonemus (sensu stricto) 
apparently may sometimes, however, gain access to the respiratory system of the bee, for the author found a specimen of a male Tarsonemus in one of the thoracic tracheae of a healthy hive bee from Golders Green.

The Joint Committee on Research in Animal Nutrition of the University of Aberdeen and the North of Scotland College of Agriculture has issued a leaflet containing the following "Instructions for the Control of Acarine Disease" (see "Bee World," October, 1920-April, 1921, p. 108) :-

"1. Weak stocks which crawl in spring should be examined for Tarsonemus woodi. If found, the stock should be destroyed. This may be done by burning sulphur within the hive. Such procedure will, at the same time, disinfect the hive, frames and quilts.

2. Owners of stocks weak from any cause should adopt every possible means to prevent robbing.

3. For the present, it seems desirable to exercise the greatest caution in purchasing bees. These should be obtained only from apiaries with no recent history of disease. With regard to bees offered for sale from districts where the disease is prevalent, it should be borne in mind that Acarine disease may be present in a stock, while as yet collective crawling has not developed.

4. With a view to preventing, as far as possible, the mingling of bees of different stocks, avoid placing hives of similar appearance in rows. If this is done the hives should show some distinctive colouring.

5. General advice :-

(a) Do not attempt to winter stocks known to be diseased.

(b) If the disease show in summer before or during the honey flow-

(i) Do everything to stimulate breeding, requeen if thought desirable.

(ii) Use a crawler trap, empty it daily, burn the dead bees; never return crawlers to the hive.

(iii) If the stock become weak, prevent robbing and destroy as soon as foraging shows failing signs.

(iv) Control as far as possible the entrance of Drones to hives.

Note.-The only reliable test for the presence of Acarine disease is the finding of the infective organism. itself, within the bees. If reported present, the procedure to be adopted must be determined by the proportion of infected bees in the stock, the season of 
the year, the age and qualities of the queen, the district and amount of disease prevalent within it, the proximity of other stocks either in the same or other apiaries. The advice of experts should be taken in estimating the particular importance to be attached to these matters."

Investigations on the treatment and prevention of this disease are being carried on at the University of Aberdeen and elsewhere. The instructions given above are therefore necessarily of a preliminary nature. As our knowledge of the malady increases improved methods will be discovered.

Traps for crawlers, although no doubt very useful, only help in the elimination of very heavily infected bees. Many bees which have the mites in their tracheal tubes are still capable of flight.

During the height of the season, bees from neighbouring stocks when bringing in nectar sometimes attempt to enter the wrong hive, and, if laden, are usually admitted. It is difficult to imagine any way by which this intermingling could be entirely prevented. Drones also visit strange hives, and although they can be prevented from entering, the devices used for this purpose are not very practical, inasmuch as they interfere with the normal life of the bee community.

Mites are very resistant to chemical fumes, and it seems very unlikely that any method of fumigation can be discovered that will kill the mite without injuring the health of the bee. It seems probable that drastic methods, such as compulsory notification and destruction of all diseased stocks, will finally have to be adopted in dealing with this malignant disease of bees.

\section{ON MOUNTING MITES FOR EXAMINATION UNDER THE MICROSCOPE.}

For ordinary research purposes it is best to mount mites in glycerine jelly or in glycerine diluted with water. Owing to its higher refractive index, balsam is not a very suitable medium for mounting Acari, for it is difficult to see delicately chitinized plates, etc., when it is used. In order to study the external morphology of mites it is usually necessary to destroy as far as possible the muscles and other internal structures by soaking in 10 per cent. caustic potash solution. Spirit specimens of parasitic Gamasid mites often contain coagulated blood, which is very difficult to dissolve; they should be pricked with a very fine needle and well boiled in caustic potash, the blood when sufficiently softened being 
pressed out with the help of blunt needles. After treating with potash, neutralize with strong acetic acid (50 per cent.), then wash in water and pass into glycerine jelly. Glycerine jelly preparations should be ringed with gold size, twenty-four hours after mounting, and finally ringed again with some suitable cement. Soft bodied mites such as Tyroglyphidae are best examined in liquid media such as very weak glycerine, and. slides with a hollow cell should be used for this type of mount, for built-up cells are liable to leak. For permanent preparations, euparal is very suitable. Specimens should be passed through alcohols of increasing strength into absolute alcohol and then into euparal. Whilst in alcohol they can be stained with picric acid or Congo red, or other suitable chitin stains.

Farrant's medium is also very suitable for mounting mites, and so are the various combinations with gum Arabic as a base (see Lee's Microtomist's Vade-Mecum).

\section{LITERATURE.}

Owing to considerations of space only works of a comprehensive nature are given below:-

Banks, Nathan. The Acartina or Mites. A Review of the Group for the use of Economic Entomologists. Report No. 108. Office of the Secretary, U.S. Dept. Agric. 1915.

Berlese, Prof. A. Acari, Mrriopoda et Scorptones hujusque in Italia Reperta. 1882-1903.

Ii. Gli Insetti, loro Organizzazione, Sviluppo, Abitudini e Rapporti coll' uomo. Vol. ii, Fasc. 1-6, 1912-13.

Canestrini, G. Prospetto dell' Acarofauna Italiana. In 8 parts, 1885-1899.

Canestrini, G., and Kramer, P. Demodicidae und Sarcoptidae. "Das Tierreich," 7 Lieferung, 1899.

Hirst, Stanley. Studies on ACArI. No. 1. The Genus Demodex, Owen. 1919.

Mégnin, P. Les Parasites et Maladies Parasitaires. 1880. Neumann, Prof. L. G. Traité des Maladies Parasitaires nonMicrobiennes des Animaux Domestiques.

Id. Parasites et Maladies Parastatares des Oiseaux DomesTIQUES. Paris. 1909.

Id. Parasites et Maladies Parasitaires du Chien et du Chat. Paris, 1914.

Railliet, Prof. A. Trattí de Zoologte Mídrcale et Agricole. 2nd Edition. Paris, 1895. 


\section{N D E X.}

Acarapis, $94 ; A$. woodi, 94 Acarine disease, of bees, 94 Aleurobius farinae, 71 Analges bifidus, 65

Analgesidae, 11, 13, 61

Beo disease, Acarine, 94

Camel ; sarcoptic mange of, 30

Cancer in hen, 60

Canker in cat, 23; in dog, 23

Cat, canker or parasitic otitis of, 23 ; mange of, 47 ; pseudoparasite of, 56 (fig.), 74

Cattle, Chorioptic or symbiotic mange of, 23; Demodex and demodectic mange of, 64 (fig.), 83 ; ear mite of, 84 (fig.) 91,92 ; Psoroptes and psoroptic mange of, 16, 17 (fig.), 21; sarcoptic mange of, 25

Cheese mites, 71

Cheletoides, $75 ;$ C. uncinata, 76

Cheyletiella, $73 ; C$. parasitivorax, 56 (fig.), 73

Cheyletinae, 69, 72,

Cheyletus, 72

Chirodiscoides caviae, 52 (fig.), 69

Chorioptes, 15, 16 (fig.), 22 (fig.)

Chorioptic mange, 23, 34, 45

Cnemidocoptes, 51 ; C. laevis, 55; C. laevis, var. gallinae, 33 (fig.), 54 ; var. phasiani, 55; C. mutans, 31 (fig.), 32 (fig.), 51 ; $C$. prolificus, 55

Cytoleichus nudus, 34 (fig.), 59, 60 ; C. banski, 59

\section{Dairyman's itch, 25}

Demodectic mange, of cat, 86 ; of cattle, 83 ; of goat, 86 ; of horse, 80 ; of pig, 82 ; of sheep, 85
Demodex, 11, 61 (fig.), 79; D. bovis 64 (fig.), 65 (fig.), 66 (fig.), 83; D. canis, 25, 62 (fig.), $79 ; D$. canis, var. ovis, 63 (fig.), 84; $D$. caprae, 86 ; D. cati, $86 ;$ D. equi, 46, 62 (fig.), 80 ; D. phylloides, 63 (fig.), 82

Demodicidae, 13, 78

Depluming iteh, 54

Dermanyssus, 66 (fig.), 87; D. aegyptius, 76 (fig.), 87 ; D. gallinae, 67 (fig.), 68 (fig.), 69 (fig.), 70 (fig.), 71 (fig.), 72 (fig.), 73 (fig.), 87, 89; D. muris, 74 (fig.), 87 ; D. passerinus, 87 ; D. sanguineus, 75 (fig.), 87

Dermoglyphus elongatus, 49 (fig.), 64 ; D. minor, 64

Dog, canker or parasitic otitis of, 23 ; follicular or demodectic mange of, 62 (fig.), 79 ; notoedric mange of, 48 ; sarcoptic mange of, 25

Dromedary; sarcoptic mange of, 30

Epidermoptes bilobatus, 50 (fig.), $5 \mathbf{I}$ (fig.), 65

Eupodinae, 76

Falculifer, 63 ; $F$. cornutus, 65 ; $F$. rostratus, 36 (fig.), 65

Feather mites, 11, 61

Ferret, parasitic otitis of, 23

Follicular mange, 79

Forage mites, 70

Fowl, depluming itch of, 54 ; feather mites of, 61,64 ; internal parasitic mites of, 59 ; red mite of, 67 (fig.), 87 ; scaly leg of, 31 (fig.), 52; Syringophilus of, 57 (fig.), 74, 75

Freyana chanayi, 48 (fig.), 64 
Gamasidae, 11, 13, 86

Gamasus, 92

Glycyphagus cadaverum, $71 ; G$. domesticus, 54 (fig.), $71 ;$ T. ornatus, 71

Goat, Chorioptes of, 23 ; demodectic mange of, 86 ; Psoroptes and psoroptic otitis of, 17 (fig.), 21 ; sarcoptic mange of, 29

Goose, nasal parasite of, 89 (fig.), 91 (fig.), 92

Grain mites, 71

Guinea-pig, pseudoparasite of, 52 (fig.), 69 ; Sarcoptes of, 25

Haemogamasus, 91 ; H. oudemansi, 91

Halarachne, 86

Harpirhynchus, 76; H. nidulans, 76

Harvest bugs, 77

Holothyridae, 13, 93

Holothyrus, 92 (fig.), 93 ; H. coccinella, 93

Horse, Chorioptes or Symbiotes and chorioptic mange of, 23, 45 ; Demodex and demodectic mange of, 46, 62 (fig.), 80 ; Psoroptes and psoroptic mange of, 17 (fig.) 44; Sarcoptes and sarcoptio mange of, 26 (fig.), 34

Hypodectes, 36 (fig.), 63

Hypopial nymphs, of Faculifer, 36 (fig.), 63 ; of Tyroglyphidae, 53 (fig.), 70, 71

Insecta, 11

Isle of Wight Bee Disease, 94

Laelaps, 91 ; L. echidninus, 83 (fig.), 91 ; L. nuttalli, 91

Laminosioptes cysticola, 35 (fig.), 59

Leptus, 77; L. (Trombicula?) autumnalis, 77 ; L. (Microtrombidium?) guineense, 78 ; $L$. (Trombicula?) simitis, 59 (fig.), 78

Liponyssus, 88 ; L. bursa, 78 (fig.), 79 (fig.), 80 (fig:), 81 (fig.), 82 (fig.), 89 ; L. sylviarum, 79 (fig.), 80 (fig.), 81 (fig.), 89, 90; $L$. suffuscus, 90
Listrophoridae, 13, 68

Listrophorus, 69; L. gibbus, 69; L. mustelae, 69

Lophoptes patavinus, 90

Megninia, 37 (fig.), 63; M. columbae, 38 (fig.), 39 (fig.), 64, 65 ; M. cubitalis, $63 ; M$, cubitalis var. ginglymura, 40 (fig.), 64 ; M. velata, 40 (fig.), 64

Metathrombidium poriceps, 77

Mounting mites, 104

Myobia, 55 (fig.), 73

Myxosarcoma, 60

Nosema apis, 94, 99

Notification of mange in horses, 44 ; of scab in sheep, 20

Notoedric mange, in cat, 47 ; in dog, 48 ; in rabbit, 50

Notoedrus, 46 ; N. cati, $47 ; N$. cati, var. cuniculi, 28 (fig.), 29 (fig.), 50 ; N. muris, 30 (fig.), 51

Otacariasis, of cat, 23 ; of dog, 23 ; of goat, 21 ; of horse, 43 ; of rabbit, 21

Otodectes, 15 (fig.), 23

Otodectes cynotis, var. canis, 23 , 24 (fig.) ; $O$. cynotis, var. felis, 15 (fig.), 23

Parasitic otitis, of cat, 23 ; of dog, 23; of goat, 21 ; of horse, 43 ; of rabbit, 21

Parasitidae, 11

Pig, Demodex and demodectic mange of, 63 (fig.), 82; Sarcoptes and sarcoptic mange of, 25,28

Pigeons, depluming itch of, 5i: feather mites of, 63,65 ; Syringophilus, of, 57 (fig.), 75

Pilicolous mites, 7, 68, 72, 74

Pityriasis, 67

Pneumonyssus, 86

Psorergates, 55 (fig.), 73, 78

Psoroptes, 11, 15, 16 (fig.), 43 ; $P$. communis, 16 ; $P$. communis, var. bovis, 17 (fig.); var. caprae, 17 (fig.), 21 ; var. cervinae, 17 
(fig.) ; var. cuniculi, 17 (fig.), 21, 44 ; var. equi, 17 (fig.), 44 ; var. ovis, 17 (fig.), 18 (fig.), 19 (fig.), 44; P. hippotis, 44; $P$. natalensis, 16, 17 (fig.)

Psoroptic mange, in cattle, 21 ; of goat, 21; of horse, 34, 44: of rabbit, 21 ; of sheep, 17

Pterolichus bicandatus, 43 (fig.), 44 (fig.), 64 ; $P$. obtusus, 41 (fig.), 42 (fig.), 64 ; $P$. sculpturatus, 43 (fig.). 44 (fig.), 64; Pterolichus sp. 45 (fig.), 46 (fig.), 47 (fig.)

Pterophagus strictus, 65

Ptilonyssus nudus, 93

Rabbit, Cheyletiella of, 56 (fig.), 74 ; Listrophorus of, 69; Notoedrus and notoedric mange of, 28 (fig.), 29 (fig.), 50 ; Psoroptes and psoroptic mange of, 17 (fig.), 21, 44 ; Sarcoptes and sarcoptic mange of, 33

Raillietia, 91 ; $R$. auris, 84 (fig.), 85 (fig.), 87 (fig.), 91

Rats, $30,51,74,77,79,87,89,91$

Red mite of fowl, 87

Rhinonyssus, 93

Rivoltasia bifurcata, 65

Sarcopterinus, 76 ; S. nidulans 76

Sarcoptes, 11, 24, 39 ; S. scabiei, var. canis, 25; var. caprae, 30 ; var. equi, 26 (fig.), 27 (fig.), 34 ; var. ovis, 29 ; var. suis, 28

Symbiotes, 15, 16 (fig.), 22 (fig.)

Sarcoptic mange, of camel, 30 ; of cattle, 25; of dog, 25; of dromedary, 30 ; of goat, 29; of horse, 34; of pig, 25; of rabbit, 33 ; of sheep, 28

Sarcoptidae, 13, 15

Sarcoptoidea, 15

Scab in sheep, 17

Scaly-leg, 52

Schöngastia americana, 60 (fig.), 78 Scutacarus, 94

Sheep, Chorioptes or Symbiotes of, 22 (fig.), 23 ; Demodex and demodectic mange of, 63 (fig.), 84 ; Psoroptes and psoroptic mange or scab of, 17 (fig.), 18 (fig.), 19 (fig.), 44; Sarcoptes and sarcoptic mange of, 28

Spirochaeta gallinarum, 88

Staphylococcus pyogenes albus,79

Sternostomum, 92 ; S. cryptorhynchum, 93

S. rhynolethrum, 89 (fig.), 91 (fig.), 92 Symbiotes, 15, 16 (fig.), 22 (fig.)

Symbiotic mange, 23, 34, 45

Syringophilus, 11, 65, 74; S. bipectinatus, 57 (fig.), 58 (fig.), 74, 75; S. columbce, 57 (fig.), 58 (fig.) 75

Tank for dipping horses, 43

Tarsonemidae, 13, 94

Tarsonemus, 94, 100 (fig.), 101 ; T. apis, 101 (fig.)

Tracheal tubes of Otodectes, 15 (fig.) ; of Listrophoridae, 52 (fig.), 69

Trombididae, 13,72

Tropical fowl mite, 89

Tydeus, 76 ; T. molestus, 58 (fig.), 76

Tyroglyphidae, 13, 61, 70, 71:

Tyroglyphus longior, 71 ; T. longior, var. castellanii, 53 (fig.) 
LONDON :

PRINTED BY WIJLLAN CLOWES AND SONS, LIMITED,

DUKE S'TREFT, STADFORD STREET, SAE. 1, AND GPEAT WINDMILL STREET, W. 1 


\section{NATURAL HISTORY MUSEUM.}

\section{Economic Pamphlets.}

No. 1.-The House-Fly as a Danger to Health. Its Life-history, and how to deal with it. By Major E. E. Austen, D.S.O. Third Fraition. Pp. 16: 3 plates (containing 6 figures), and 5 figures in text. 1920, 8ro. 3d. (postage 1 d.)

No. 1A.-The House-Fly. Its Life-history, and Practical Measures for its Suppression. By Major E. E. Austen, D.S.O. Pp. 52 : 3 plates (containing 6 figures) and 5 text-figures. 1920, 870. 1s. 6d. (postage 2d.).

No. 2. - The Louse as a Menace to Man.-Its Life-history, and Methods for its Destruction. By James Watierston, B.D., D.Sc. Pp. 20 : 1 plate (containing 2 figures), and 2 figures in text. 1921, 870. 6d. (postage 1d.).

No. 3-Fleas as a Menace to Man and Domestic Animals. Their Life-history, Habits, and Control. By James Waterston, B.D., D.Sc. Second Edition. Pp. 21 : 1 plate and 6 text-figures. 1920, 8vo. 4d. (postage $1 \frac{1}{2} d$.)

No. 4.-Mosquitoes and their Relation to Disease. Their Lifehistory, Habits, and Oontrol. By F. W. Edwards, B.A. Second Edition. Pp. 20: 6 text-figures. 1920, 8vo. 4d. (postage 1d.).

No. 5.-The Bed Bug. Its Habits and Life-history, and how to deal with it. By Bruce $\mathrm{F}$. Oummings. Second Edition. 1918, Pp. $20: 7$ text-figures. 8vo. 2d. (postage 1d.).

No. 6.-Species of Arachnida and Myriopoda (Scorpions, Spiders, Mites, Tioks, and Centipedes, Injurious to Man). By S. Hirst. Second Eidition. Pp. 59: 26 text-figures and 3 plates. 1920, 87.o. 1s. (postage 2d.).

No. 7.-The Biology of Waterworks. By R. Kirkpatrick. Second Edition. Pp. $5 \tilde{8}$ : 18 text-figures. 1917, 8vo. 1s. (postage $2 d$.).

No. 8.-Rats and Mice as Enemies of Mankind. By M. A. C. Hinton. Second Edition. Pp. 67: 6 text-figures and 2 plates. 1920, 8 vo. 1s. (postage 2d.).

No. 9.-Birds Beneficial to Agriculture. By F. W. Frohawk. Pp. 54: 22 plates. 1919, 8vo. 2s. (postage 21 2 d.).

No. 10.-Marine Boring Animals Injurious to Submerged Structures. By W. T. Calman, D.Sc. Pp. 35: 21 text-figures. [With Index.] 1919, 8vo. 1s. (postage $1 \frac{1}{2} d$.).

No. 11.-Furniture Beetles, their Life-history and how to check or prevent the damage caused by the Worm. By C. J. Gahan, D.Sc. Pp. 23 : 1 plate and 5 text-figures. 1920, 8vo. 6d. (postage $1 d$.).

No. 12.-The Cockroach. Its Life-history and how to deal with it. By Fred merick LatNG, M.A., B.Sc. Pp. 18: 1 plate and 2 text-figures. 1921, -8vo. 6d. (postage 1d.).

No. 13.-Mites Injurious to Domestic Animals. With an Appendix on the Acarine Disease of Hive Bees. By S. HIRsT. Pp. 107: 85 text-figures. 1922, 8vo. 3s. (postáge $3 d$.).

\section{Economic Leaflets.}

No. 1.-The Danger of Disease from Flies and Lice. Second Edition. Pp. 4. 1918, 8vo. Price: 1d. for 3 copies (postage 1d.), 2s. $6 d$. for 100 (postage 6d.).

Applications to the Museum direct for any of these pamphlets should be accompanied by a remittance, including postage.

Written communications respecting them should be addressed to the Director, British Museum (Natural History), Cromwell Road, London, S.W.7. 


\section{BRITISH MUSEUM}

\section{(NATURAL HISTORY).}

\section{DAYS AND HOURS OF ADMISSION.}

The Museum is open to the Public, free daily.

The Hours of Admission are:-

On WEEK-DAYs, throughout the year from 10 A.M., in January and February ... $\quad \ldots$ to 5 P.M. March to September ... ... , 6 , October, November and December ", 5 " on Sundays, throughout the year from 2.30 P.M. to 6 P.M. The Museum is closed on Good Friday and Christmas Day.

By Order of the Trustees,

S. F. HARMER, Director. 

